

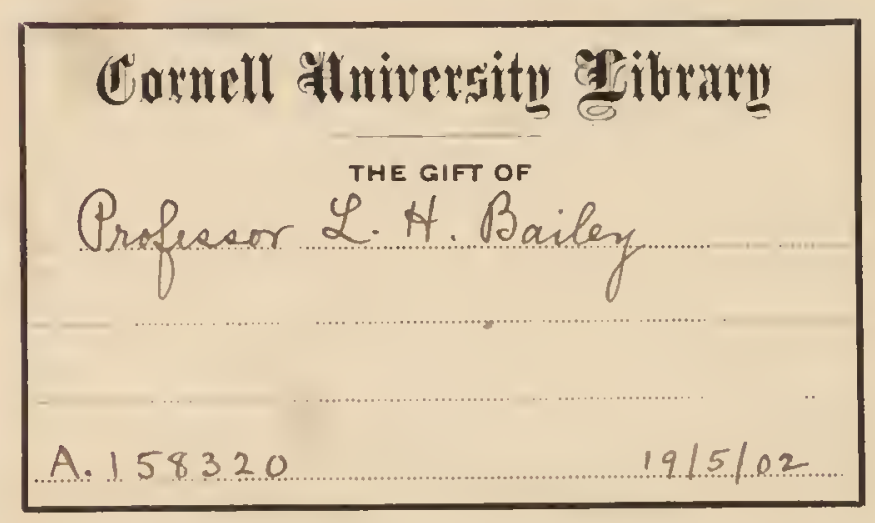

1248

ALBERT R. MANN LIBRARY

New York State Colleges

Agricuiture AND HOME ECONOMICS

CORNELl. UNIVERSITY 
DATE DUE

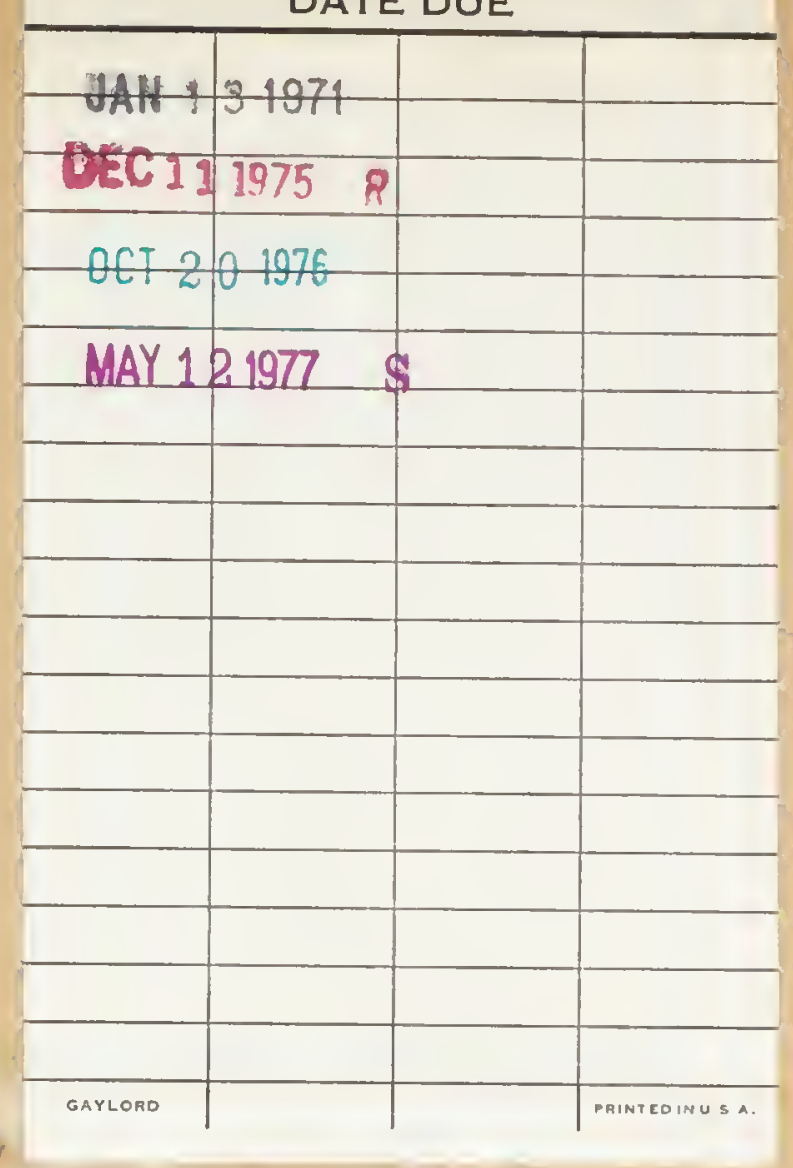





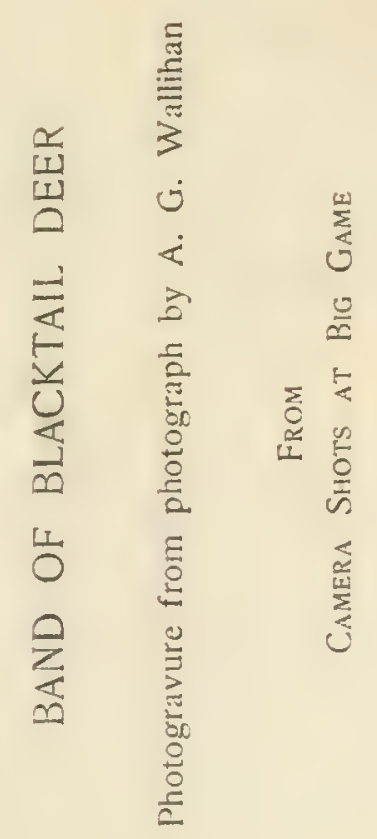





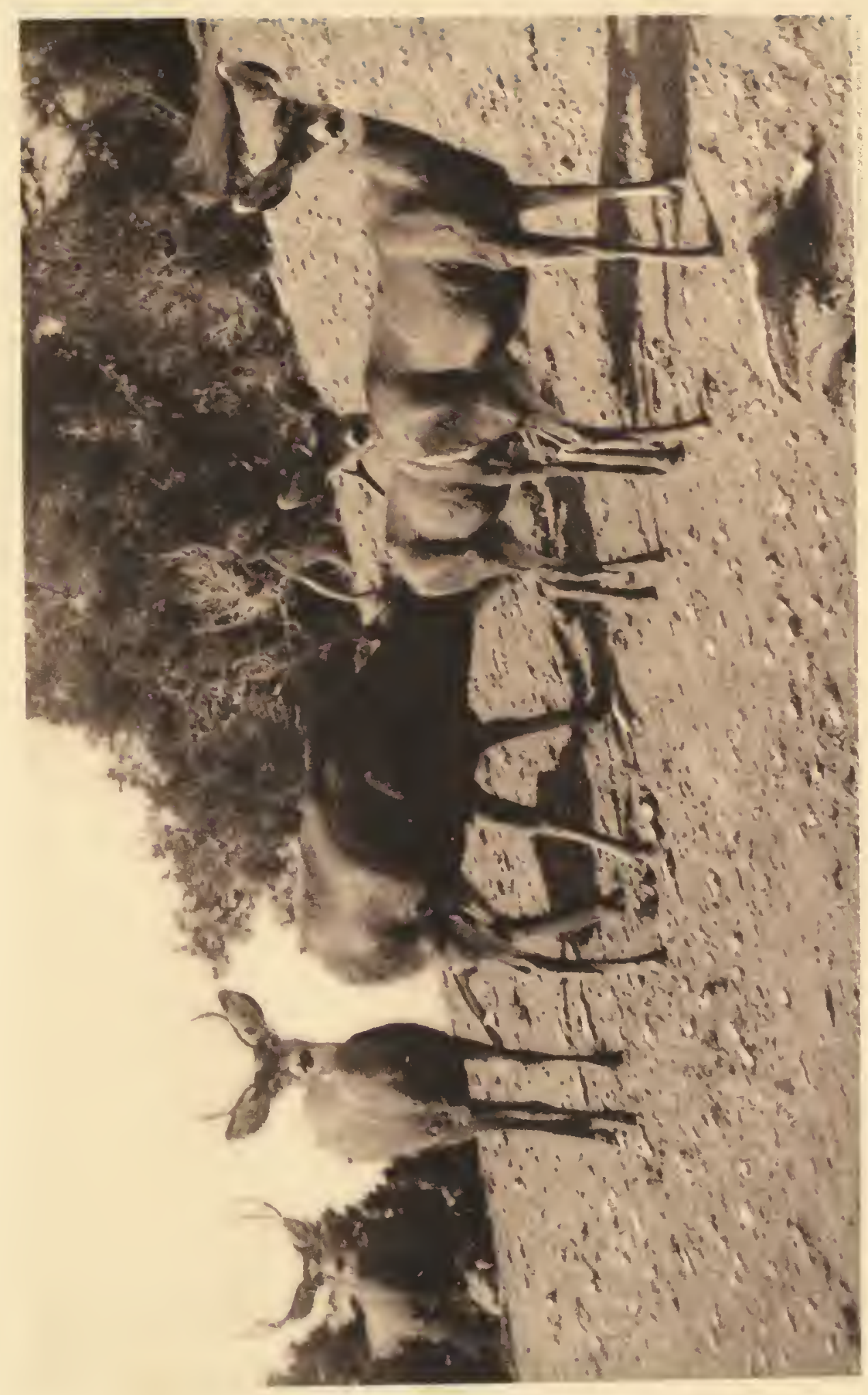



N A T U R E

PORTRAITS

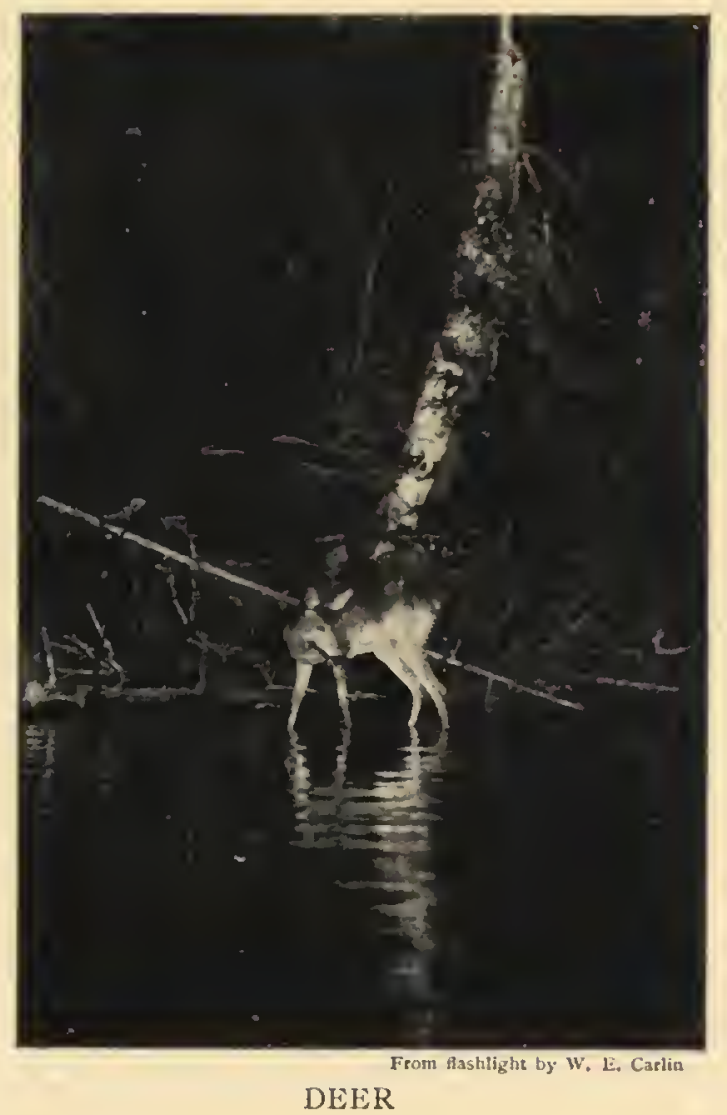

i 
밈 


\title{
NATURE PORTRAITS
}

\author{
Studies with Pen and Camera of Our Wild \\ Birds, Animals, Fish and Insects
}

\author{
TEXT BY THE EDITOR OF \\ "COUNTRY IJFE IN AMERICA"
}

WITH FIFTEEN LARGE P'LITES AND MANY ILLUS-

TRATIONS BY THE BEST NATURE PHOTOGRAPHERS

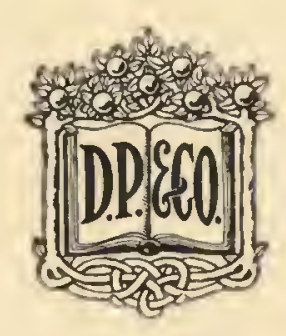

NEW YORK

Doubleday, Page \& Co.

1902 
$Q L$

46

B 15

A. $1583=0$

Copyright, 1902, by

Dolbleday, Page \& Company

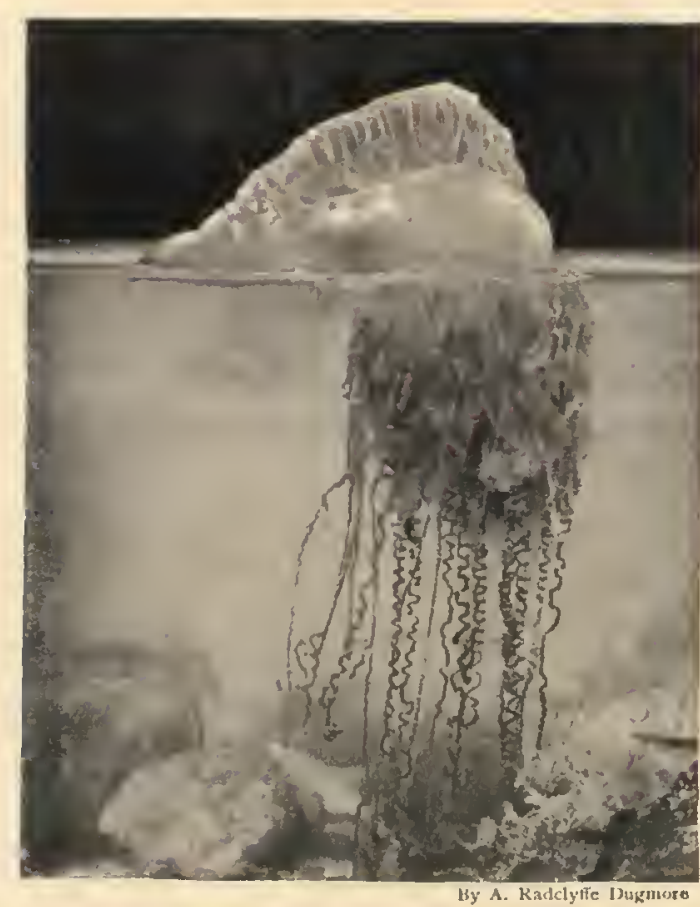

PORTLGUESE MAN-OF-WAR

All the pictures shown herein, without

exception, photographs from life, are

copyrighted. All rights reserved. 


\section{TABLE OF CONTENTS}

\section{PART I}

The Point of View towards Nature The New Hunting

PART II

MUST A "USE" BE FOUND FOR EverythiNG?

Utility. A PoeM

PART III

SCIENCE FOR SCIENCE' SAKE

PART IV

The Extrinsic and Intrinsic Views of Nature

PART V

The Poetic Interpretation of Nature

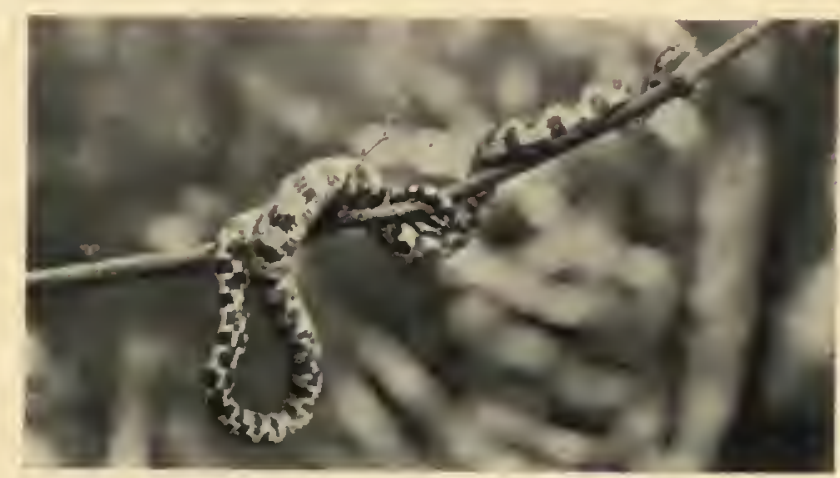

MILK SNAKE SUNNING IIMSELF 


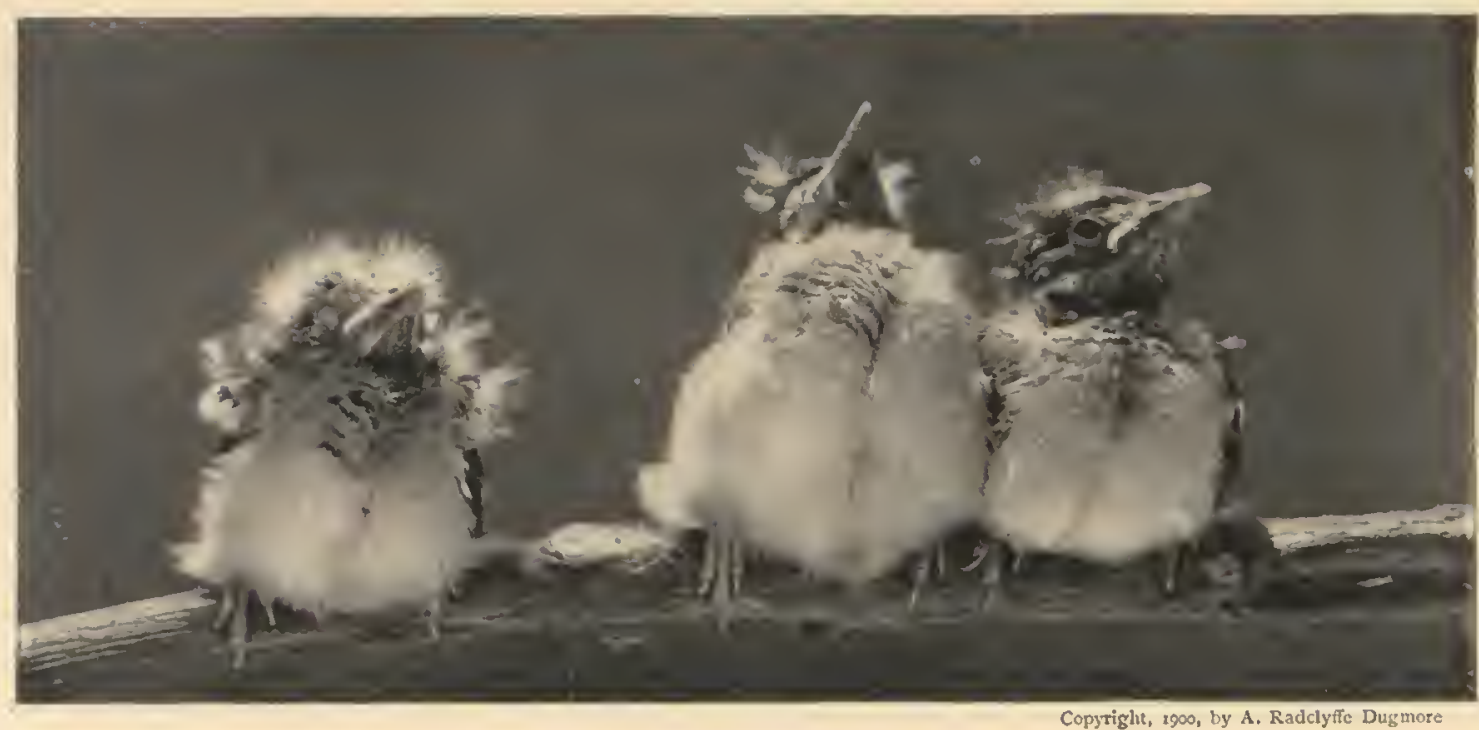

A SLEEPY TRIO

\section{LIST OF ILLUSTRATIONS}

\section{PLATES}

BAND OF BLACKTAIL DEER

Photogravure from photograph by A. G. Wallihan.

Frontispiece

KADIAK BEAR

Reproduction in full colour of a painting by Charles R. Knight.

Facing Page viii

WOODCOCK ON HER NEST

Photographic enlargement from life picture by A. Radclyffe Dugmore.

KADIAK FOX

Reproduction in full colour of painting of this newly discovered species by Charles R. Knight.

ATLANTIC SALMON

Direct contact print from the first successful photograph of a live salmon, by A. Radclyffe Dugmore.

LAND-LOCKED SALMON

Direct contact print from the first successful photograph of a live salmon, by A. Radclyffe Dugmore.

MOON-FISH

Direct contact print from a photograph of a live fish by $A$. Radclyffe Dugmore.

BROADBILL DUCK

Photographic cnlargement of a snapshot by telephoto made from a swimming wild bird by W. E. Carlin.

PAIR OF MALLARDS
A photograph from life of a pair of wild ducks by IIerbert $\dot{K}$. Job.

DEER IN THE WOODS
A snapshot made at night with a flashlight by W. E. Carlin.

CANADA LYYX

Enlarged photograph from life by W. E. Carlin.

FIELD MOUSE AND YOUNG

A snapshot of a mouse suckling her young, made from life by $A$. Radclyffe Dugmore.

A DISREPUTABLE PAIR Two owls, photographed by A. Radclyffe Dugmore.

A YOUNG BUUCK Enlargement from photograph by W. E. Carlin.

A BAND OF ANTELOPE

OF ANTELOPE
Photographic print from a negative, by A. G. Wallihan. 


\section{LIST OF TEXT ILLUSTRATIONS}

Deer, 'Alashlight, by IV. E. Carlin

Milk Snake Sunning Himself, by L. IV Brownell ${ }^{\circ} \cdot{ }^{\circ}$

A Sleepy Trio, by A. Radclyffe Dugmore . . . . . . . . . . vi

Scolding the Intruder, by A. Radclyffe Dugmore . . . . . . . viii

A Lynx, by W. E. Carlin . . . . . . . . . . . . ,

One at a Time, by A. Radclyffe Dugmore . . . . . . . . . . . . I

A Pair of Deer and a Doe, by W. E. Carlin . . . . . . . . 2

On the Alert and Alarm, by W. E. Carlin . . . . . . . . . 3

Pika and Flying Squirrels, by W. E. Carlin . . . . . . . . . 4

Prairie Dogs, by A. Radclyffe Dugmore . . . . . . . . . . 5

A Weasel and Pocket Gopher, by W. E. Carlis . . . . . . . 6

A Raccoon, by W. E. Carlin . . . . . . . . . . . 7

Western Shrew, by W. E. Carlin . . . . . . . . . . 8

Spring's Harbinger-a'The Bluebird, by WV L. Brownell • . . . . . 9

Young Mocking-bird, by A. Radclyffe Dugmore . . . . . . . . 9

Mocking-birds, eight positions, by A. Radclyffe Dugmore . . . . . . 10, I I

Canary Birds, five positions, by A. Radclyffe Dugmore _ . . . . . . . 12, 13

Three Canary Bird photographs, by A. Radclyffe Dugmore . . . . . It

Indigo Birds, two photographs, by A. Radclyffe Dugmore . . . . . 15

Canary Birds, two pictures by A. Radclyffe Dugmore _ . . . . . . . 16

Tree-frog, by W. L. Brownell . . . . . . . . . . . 17

Beaver, by A. Radclyffe Duginore . . . . . . . . . . . . 18

Beaver at Work, by A. Radclyffe Dugmore . . . . . . . . 19

Gray Foxes, two photographs, by Herbert K. Job . . . . . . . 20

Head of Gray Fox, by Herbert K. Job . . . . . . . . . . 21

Gray Foxes, two other photographs, by Herbert K. Job . . . . . . . 22

A Canary Bird, by A. Radclyffe Dugmore . . . . . . . . . . 23

Gray Fox, by Herbert K. Job . . . . . . . . . . . 23

Cedar Bird, by A. Radclyffe Dugmore . . . . . . . . . . 24

Gray Squirrel, by W. L. Brownell . . . . . . . . . . 25

From Caterpillar to Butterfly, twelve progressive pictures, by W. L. Brownell 26,27,28,29

Cocoon of Polyhemus Moth, Angle-wing Butterfly and Fox Squirrel, by W. L. Brownell 30

A Porcupine, Sparrow feeding young and a pet Canary, by A. Radelyffe Dugmore . 31

A pair of Woodchucks, by A. Radclyffe Dugmore . . . . . . . . . 32

Prairie Dogs, two pictures, by A. Radclyffe Dugmore . . . . . . 33

Rock Bass and Yellowtail, by A. Radclyffe Dugmore . . . . . . 35

Pudding-wife and Parrot-fish, by A. Radclyffe Dugmore . . . . . . 36

Little Head Porgy, by A. Radclyffe Dugmore . . . . . . . . . 37

Squirrel-fish, Rock-hind and Yellow-fin groups, by A. Radclyffe Dugmore . . . 38

Blue Fish and White or Common Grunt, by A. Radclyffe Dugmore . . . 39 


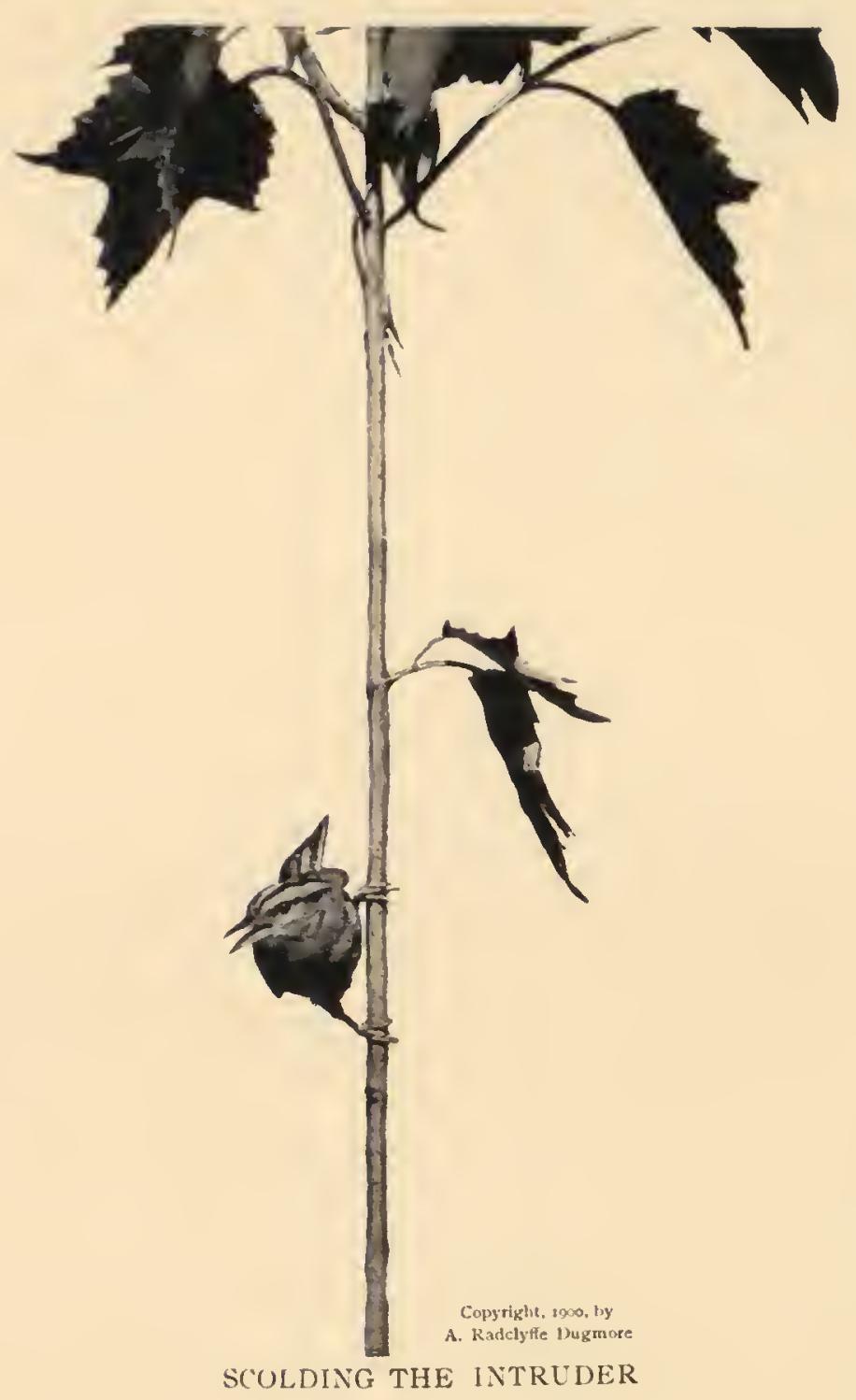

viii 


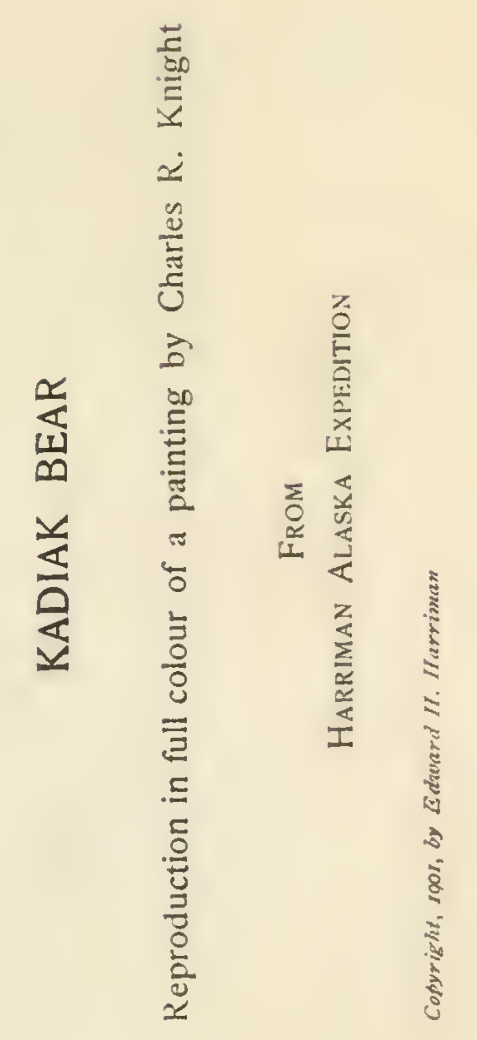





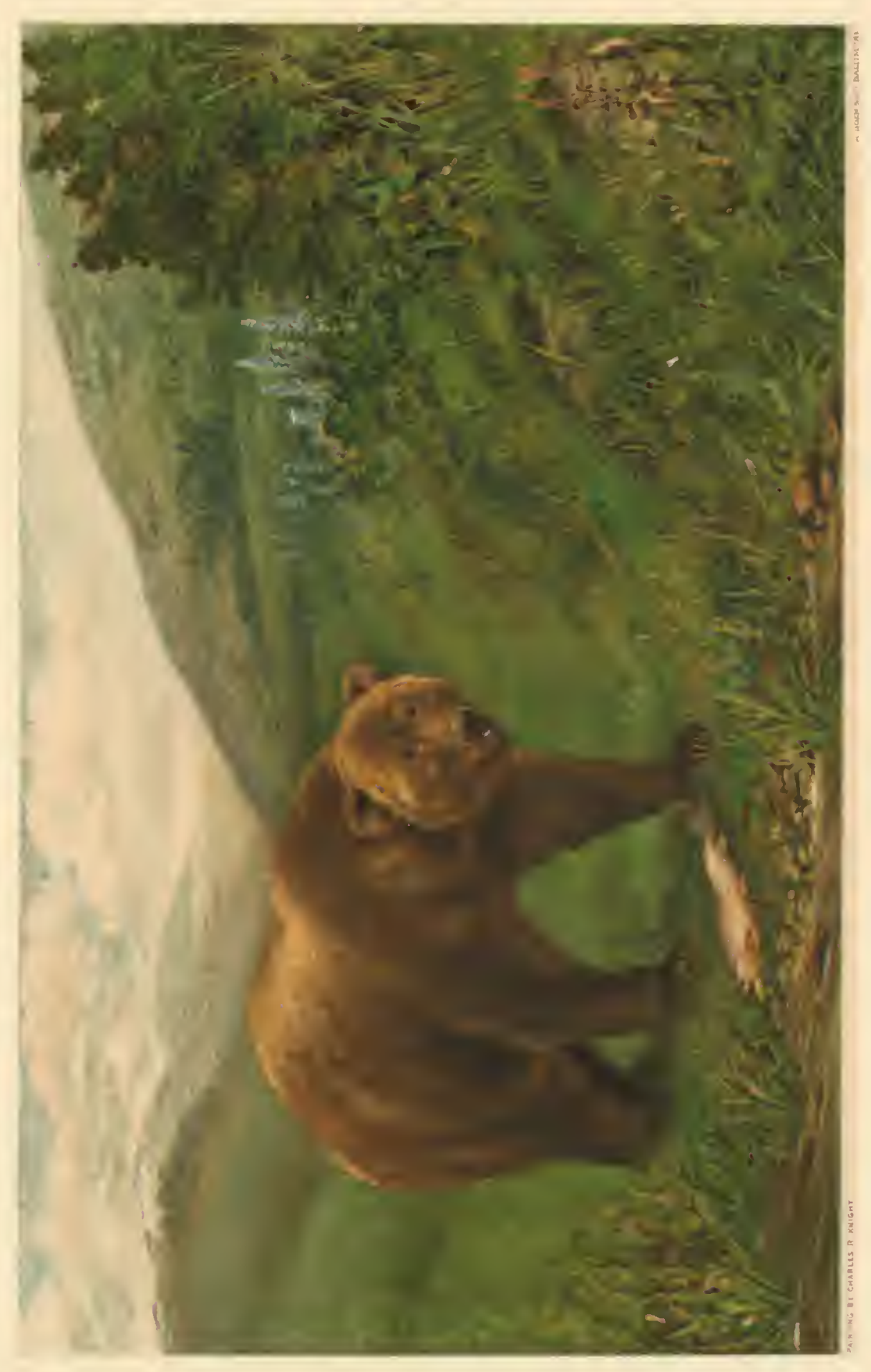





\title{
NATURE PORTRAITS
}

\author{
PART I
}

\section{THE POINT OF VIEW TOWARDS NATURE}

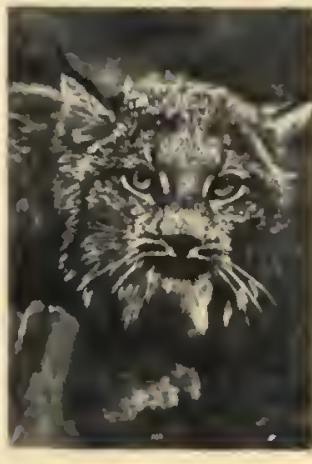

By W.

I oNCE saw two sisters standing on the doorstep bidding goodby to their husbands, who were off for a day's outing. One looked at the sky and said: "I am afraid it will rain." The other looked at the sky and said: "I know that you'll have a good time." There was one sky, but there were two women. There were two types of mind. There were two outlooks on the world. There were two points of view.

The greatest thing in the world is the point of view. It determines the current of our lives.

The satisfaction that we derive from the external world is determined by the attitude in which we consider it. The beautiful pictures in these folios suggest what there is to be seen in the common world about us. They will serve to direct and focus our observation. But merely seeing things is not enough. One must think about them. All unconsciously one's attitude of mind towards the nature-world is formed. We grow into our opinions and beliefs without knowing why. It is therefore well to challenge these opinions now and then, to see that they contain the minimum of error and of misdirection. This challenging of the point of view is the theme of the text that I am writing. The points of view are so early impressed upon us, that I have purposely chosen many illustrations from the teaching of children.

Some of the points of view

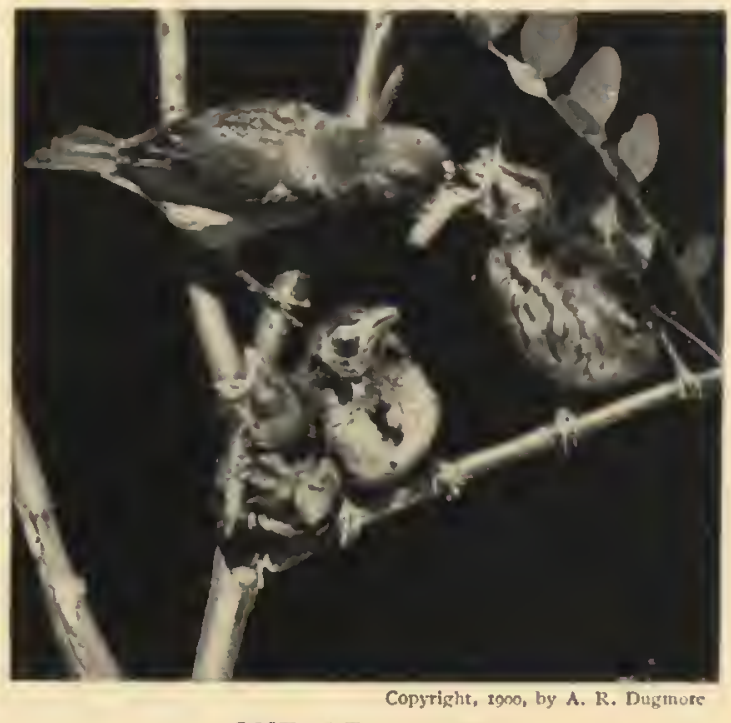

ONE AT A TIME

Wild Indigo Bird Feeding Her Young in a Locust Tree 
Nature Portraits

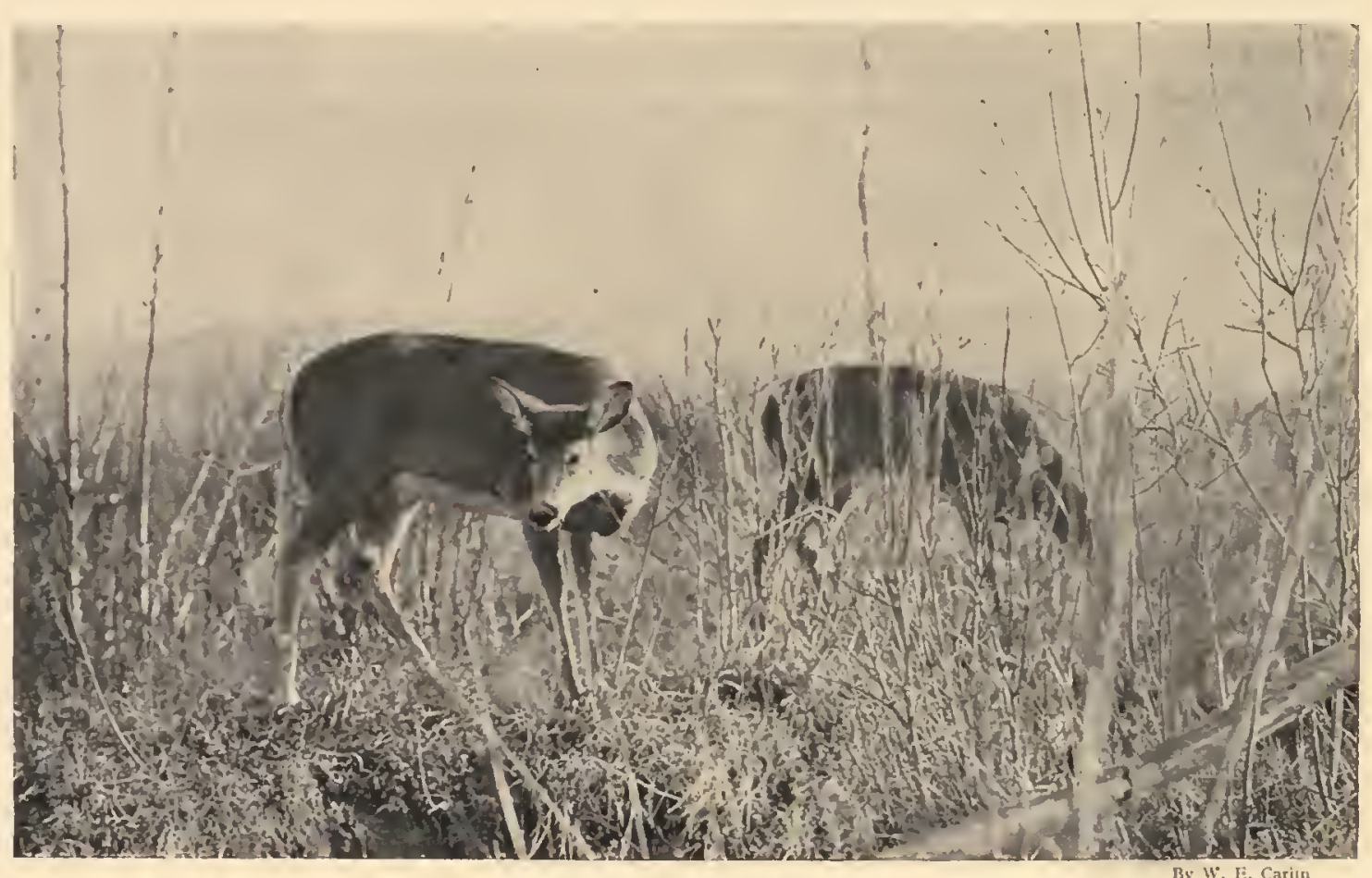

A PAIR OF DEER

that seem to me to be most in need of discussion are made the themes of these pages. These themes may be taken up in the following order, although they follow no logical sequence:

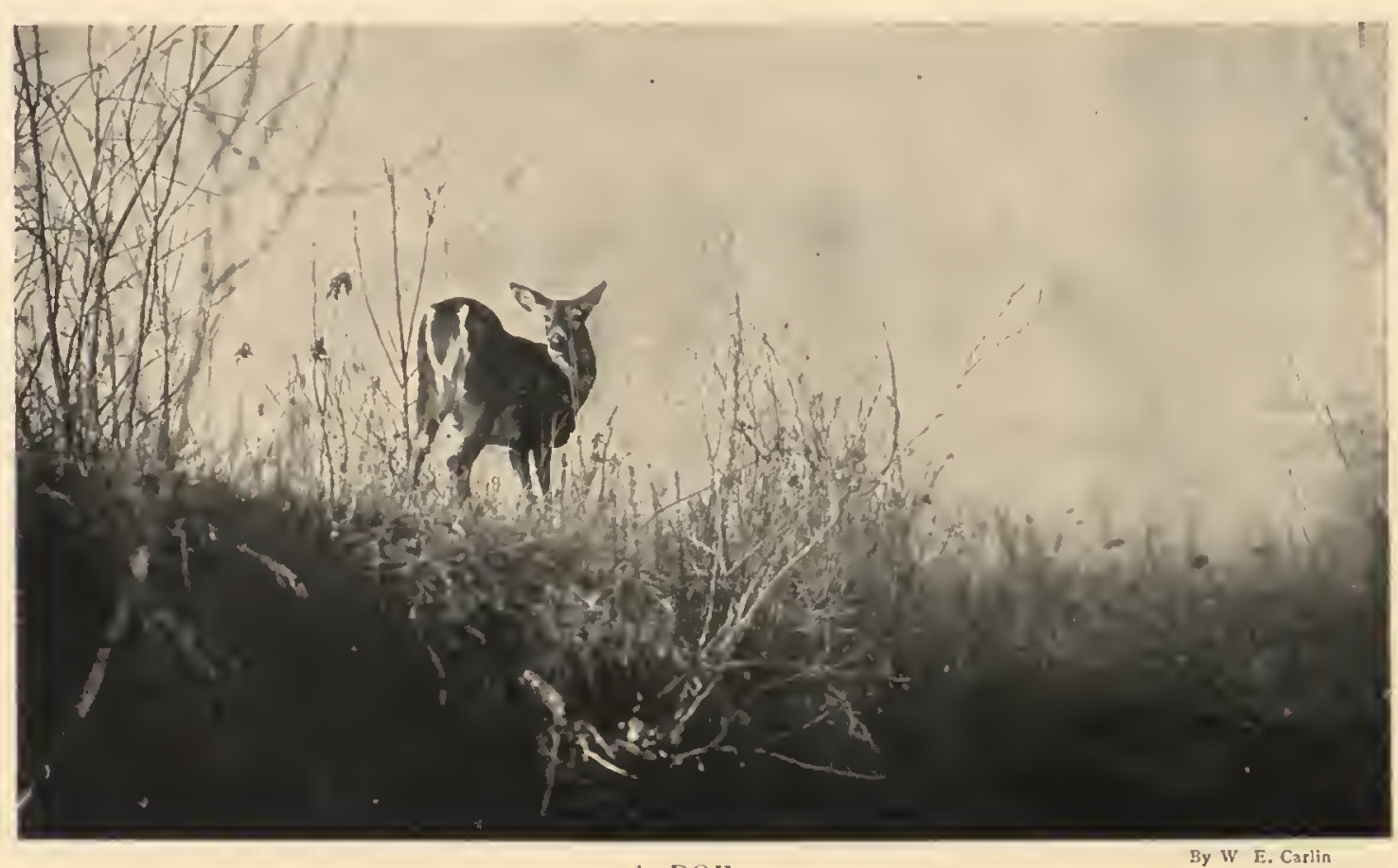

A DOE 


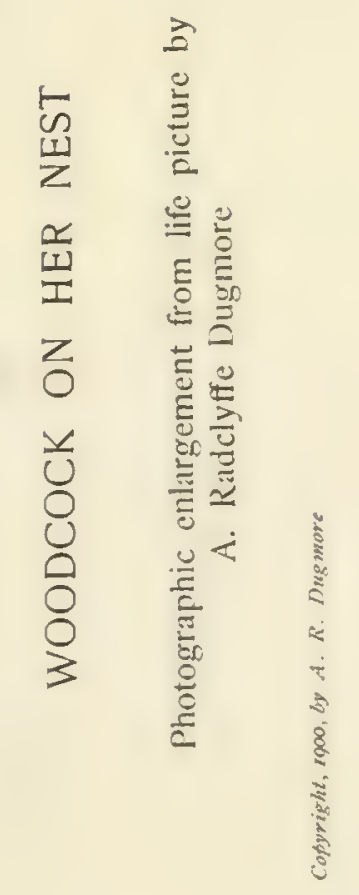





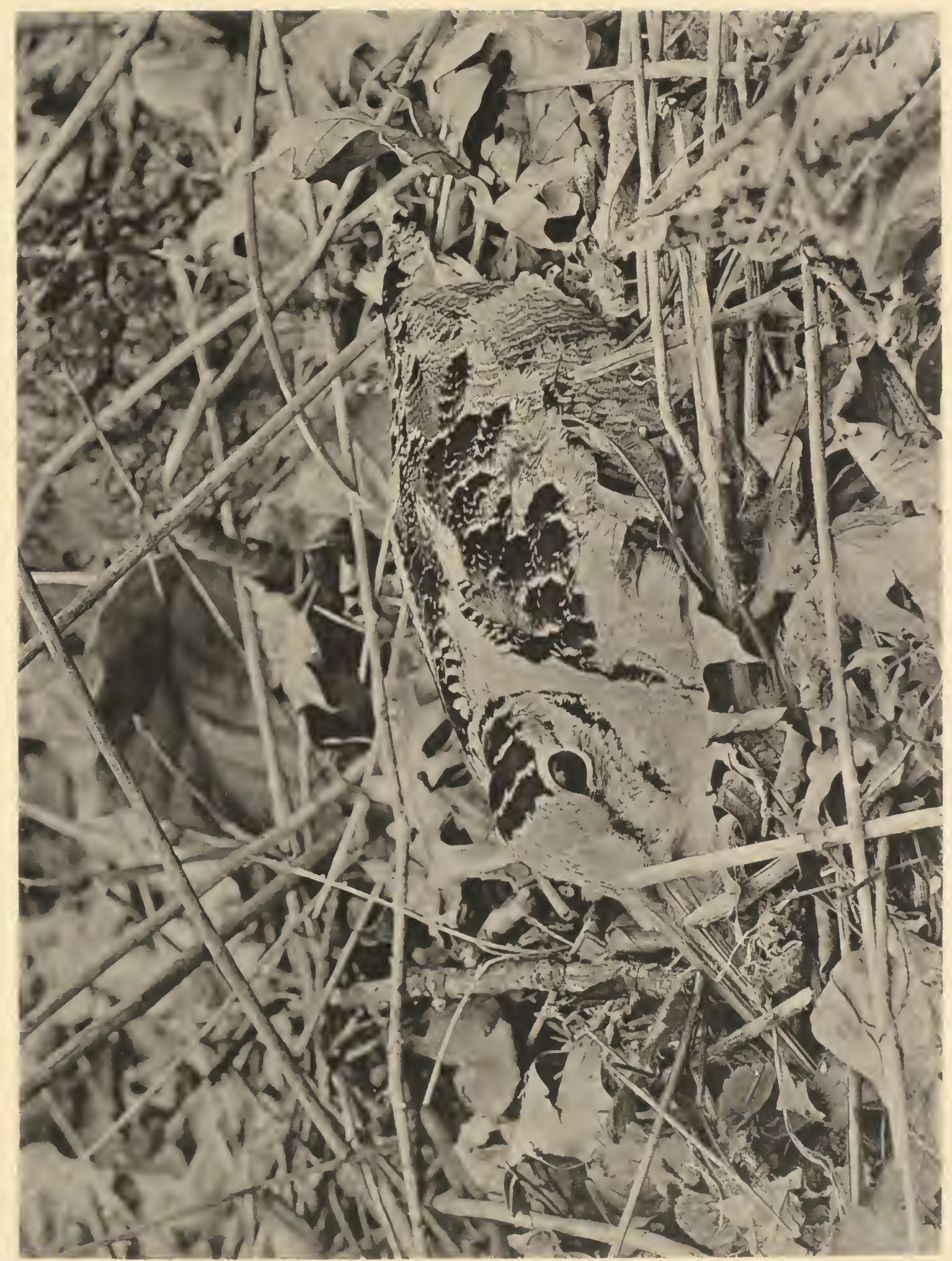





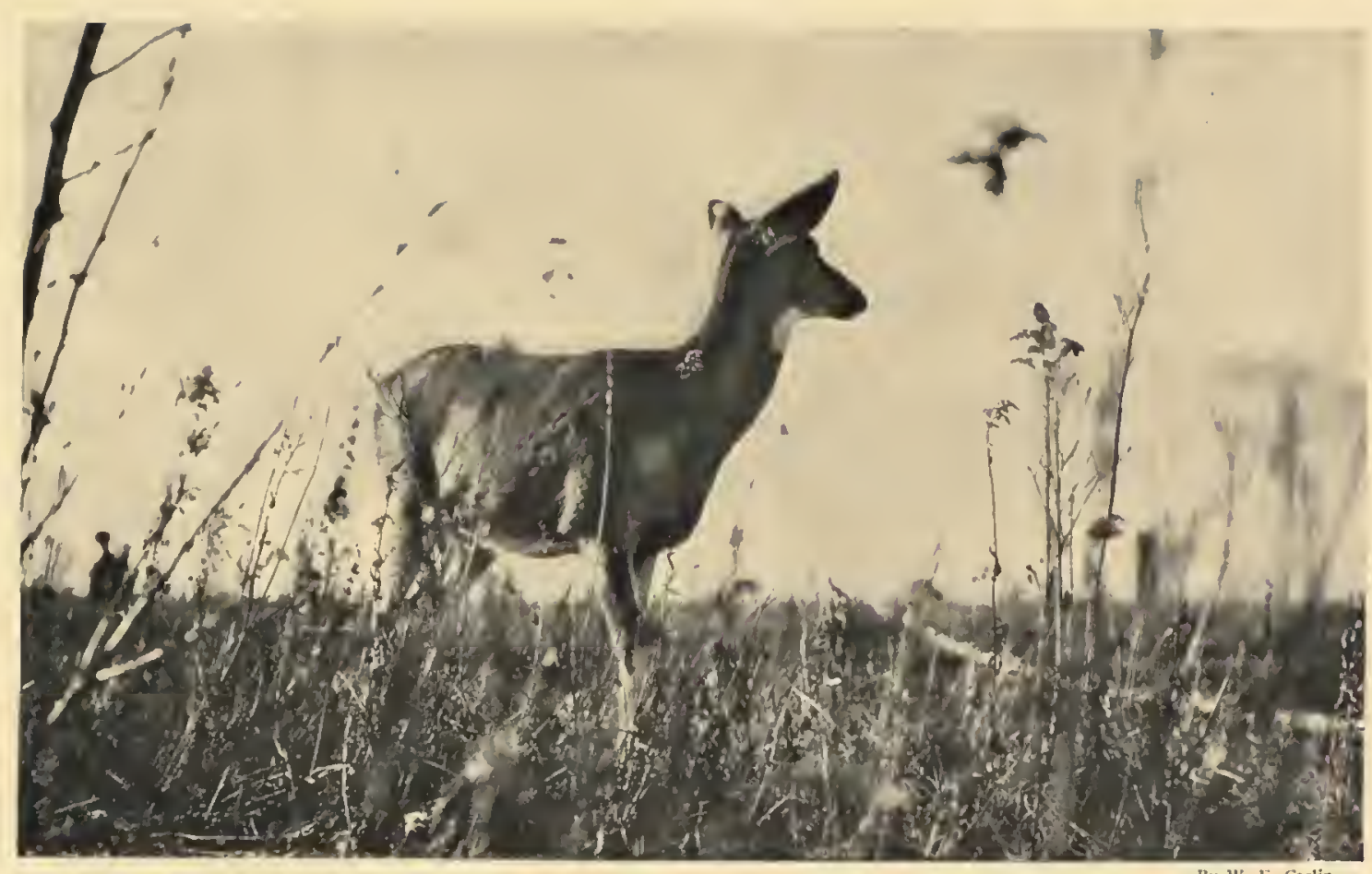

ON THE ALERT

Ry W, L. Carlin

The New Hunting.

Must a "Use" be Found for Everything?

Science for Science's Sake

The Extrinsic and the Intrinsic View of Nature.

The Poetic Interpretation of Nature.

\section{THE NEW HUNTING}

HE world is full of animals and plants. Every animal and plant has the power to multiply itself many fold. Every one contends for an opportunity to live.

This contention forces the individual to live for itself. Self-preservation, it is said, is the first law of nature. The animal appropriates food, usurps territory, kills and even devours its contestants. It kills because it must. Its acts need no justification.

Man also is an animal. He has come up from the world-fauna. On his way he contended hand to hand with the other animal creation. $\mathrm{He}$

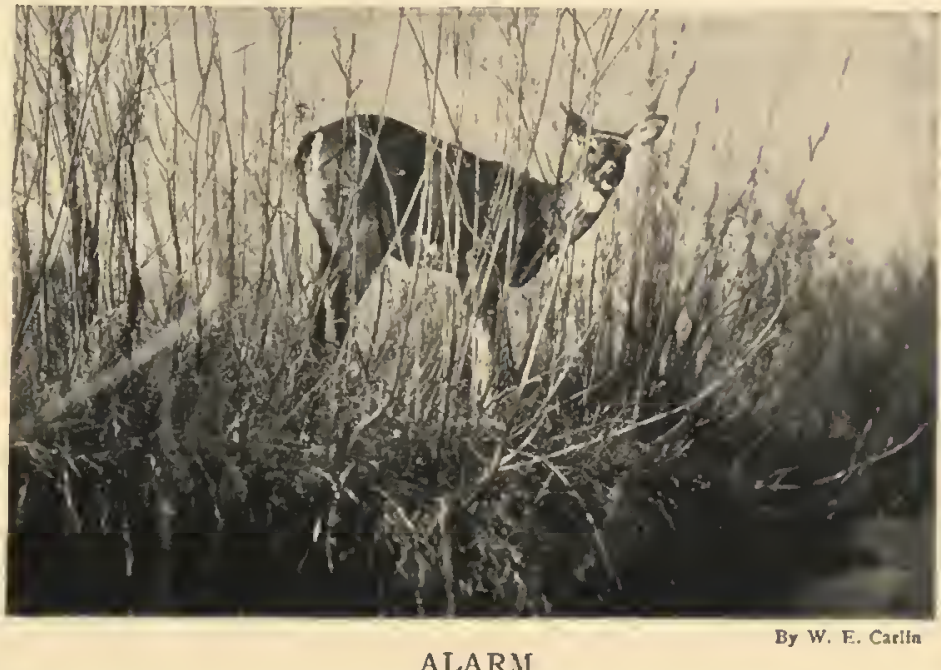

ALARMI 
killed from necessity of obtaining food. As he arose above his contestants, this necessity became less urgent. He has now obtained dominion, but he is not yet fully emancipated from the necessity of taking life. Perhaps complete emancipation will come.

The old desire to kill-first born of necessity-still lingers. But now we kill also for "sport." Practically a new motive has been born into the world with man,- the desire to kill for the sake of killing. One generation of white men is sufficient practically to exterminate the bison and several other species. All this

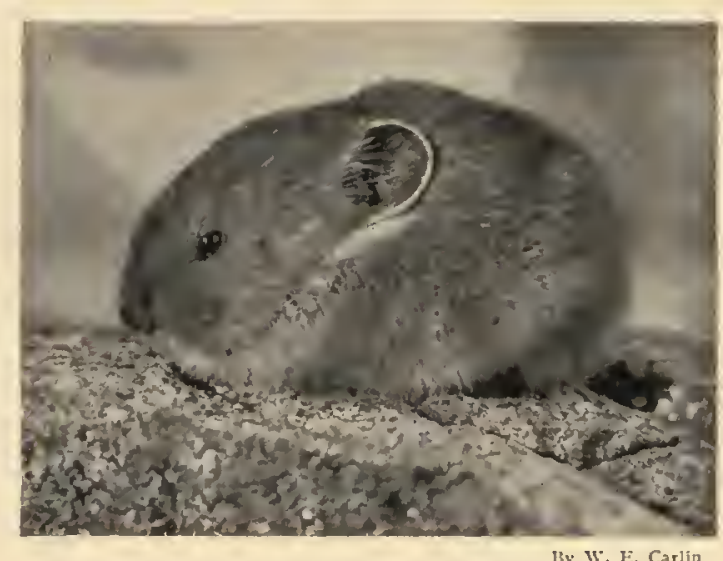

PIKA, OR LITTLE CHIEF HARE

A very difficult species to photograph. It is necessary to find a as a sunning place, set up the camera, and then retire, screened with leaves and weeds. needs justification. The lower creation is not the plaything of man.

We are still obliged to kill for our necessities. More and more we are rearing the animals that we would take for food. We give them more

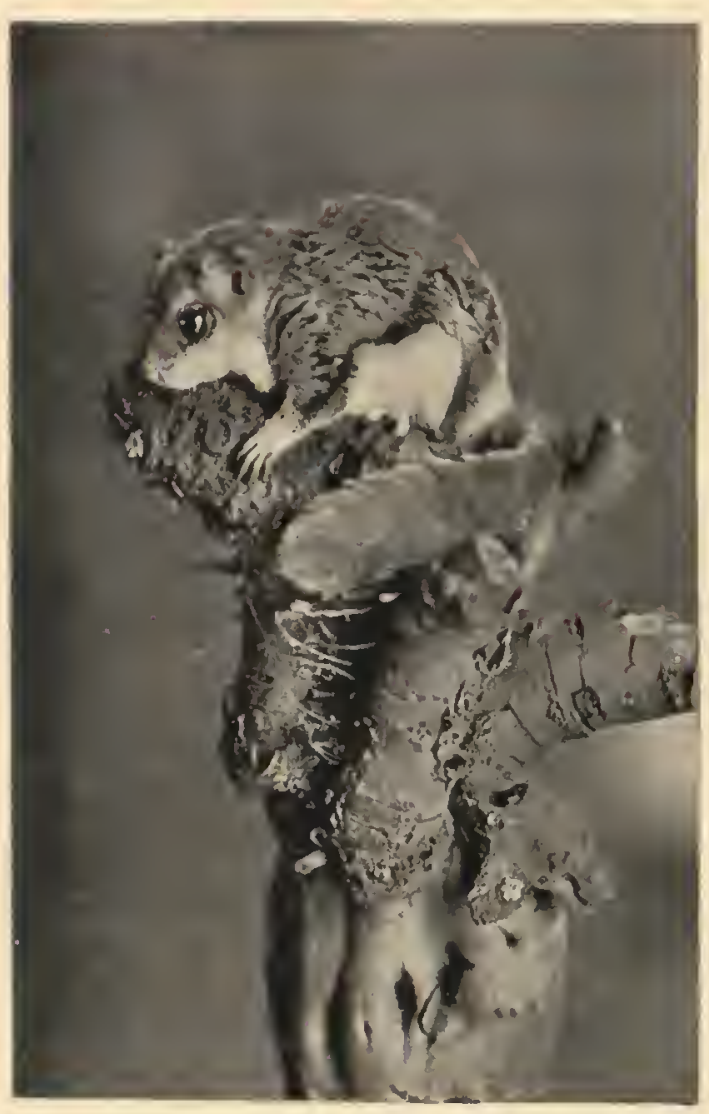

FLYING SQUIRRELS comfortable lives. We remove them from the necessities of protecting themselves from violence. We take our own. There is no question of morals. We give that we may take; and we take because we must.

To kill for mere sport is a very different matter: it lies outside the realm of struggle for existence. Too often there is not even the justification of fair play. Usually the hunter exposes himself to no danger from the animal that he would kill. He has the advantage of long-range weapons. There is no combat.

But there is another and a fairer side. The satisfaction in hunting is often the joy of skill in marksmanship, the pleasure of woodcraft, the enthusiasm of being out of doors, the keen delight in discovering the 
haunts and ways of the nature-folk. Many a hunter finds more pleasure in all these things than in the game that he bags. To the true sportsman hunting is not synonymous with. killing. It is primarily a means of enjoying the free world of the Out-of-doors. We are not to be understood as opposed to hunting with the gun or the rod. Exery man has a right to decide these questions for himself. We wish only to suggest that there are other ideals. We wish to point out the tendency to know things as they live

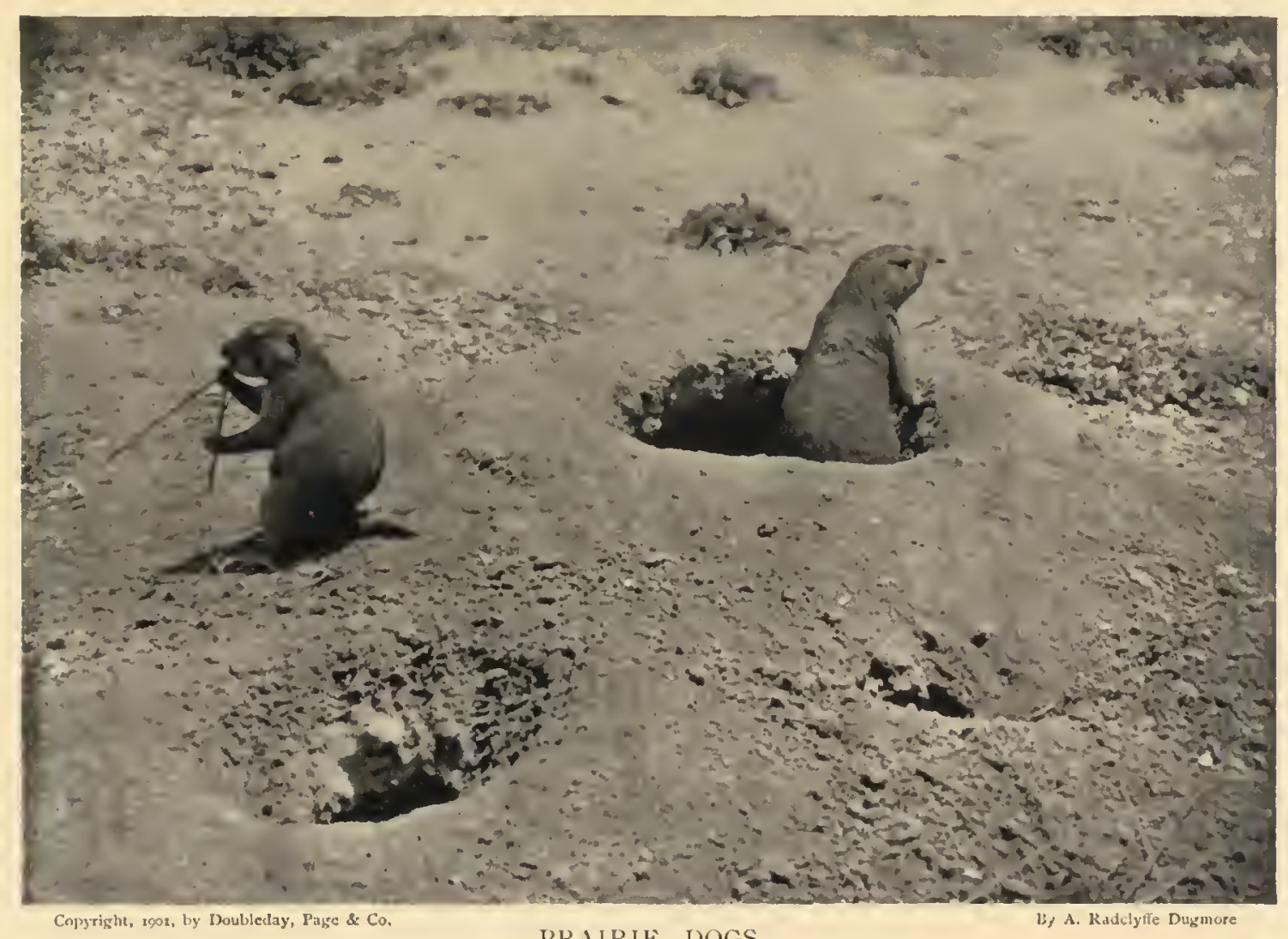

PRAIRIE DOGS

and for what they are. There was a time when animals were known mostly in museums, or books that smelled of museums. We now know them in woods and fields. We know what they do, as well as what they are.

A new literature has been born. It is the literature of the out-ofdoors. It is written from the world-viewpoint, rather than from the study viewpoint. Man is not the only, nor even the chief, actor. No longer can one write a good nature-piece until he has intimate knowledge of the animal or plant in the wild, and has tried to put himself in its place. Perhaps the old school of literary effort is not losing ground; but it is certain that the new is gaining. The new literature is founded on specific 


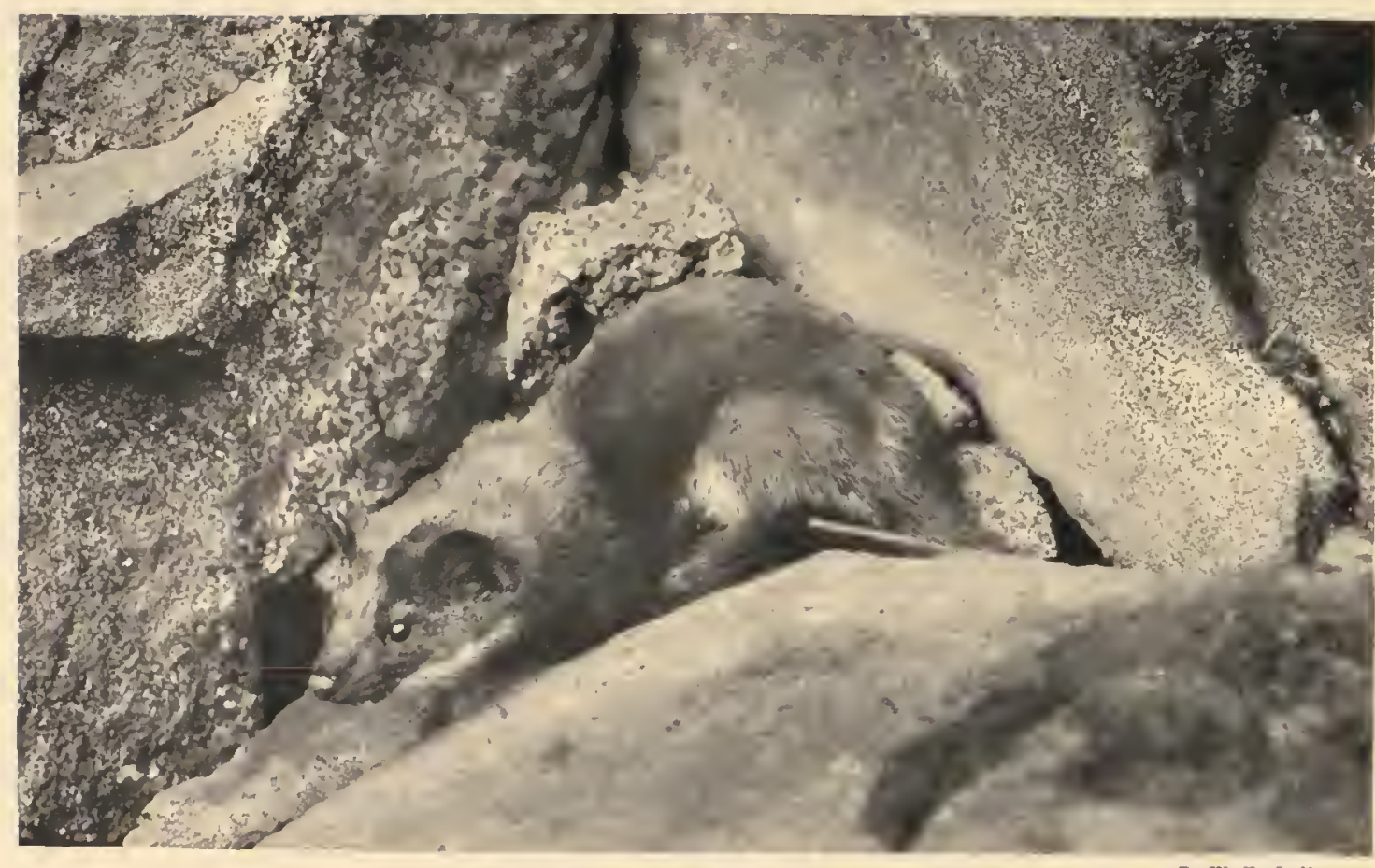

A WEASEL

By W, E, Carlin

(This very shy animal has probably never been suecessfully photographed before, and the portrait represents a hard day's work)

technical knowledge, but it embraces all the human sympathies. It is the outcome of the study of objects and phenomena. The first product of this nature-knowledge was scientific literature. The second is the lucid resourceful nature-writing of the present day.

The awakening interest in the nature-world is strongly reflected in the

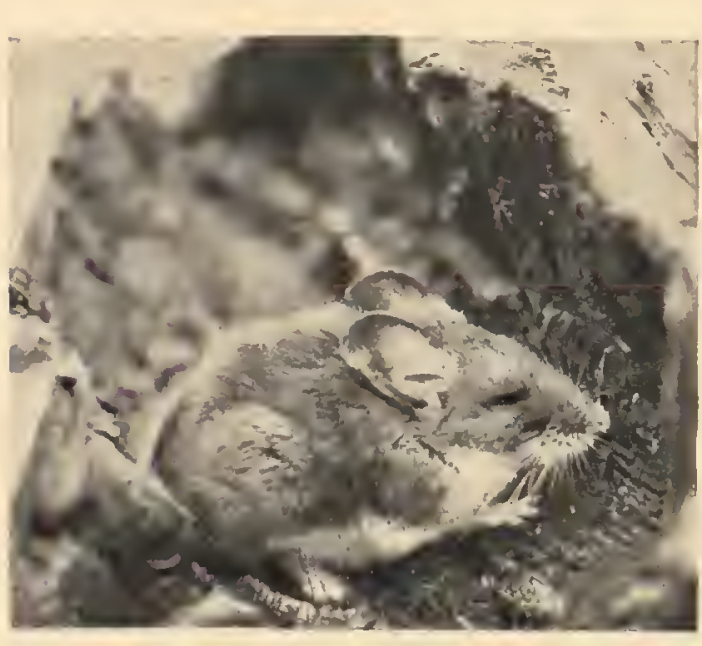

POCKET GOPHER could be made)
cet along the fell game laws,- - for these laws are only an imperfect expression of the growing desire to let everything live its own life. It is gratifying that a prominent place in the discussions for good game laws is taken by sportsmen themselves.

Another expression of this growing sympathy is exhibited in the reservation of certain areas in which animals are to be unmolested. It is a most significant fact that while many country regions are practically shot clean of animal life, sometimes 


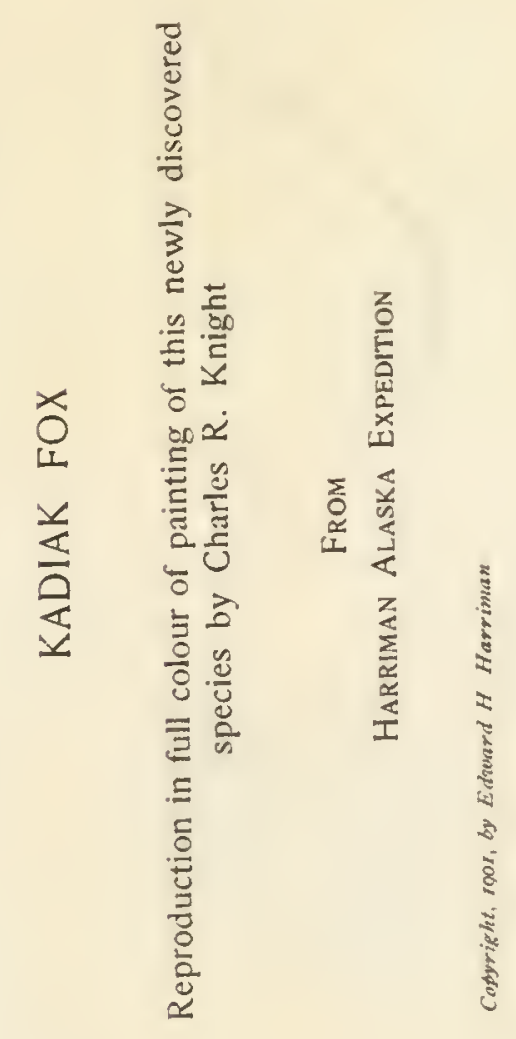





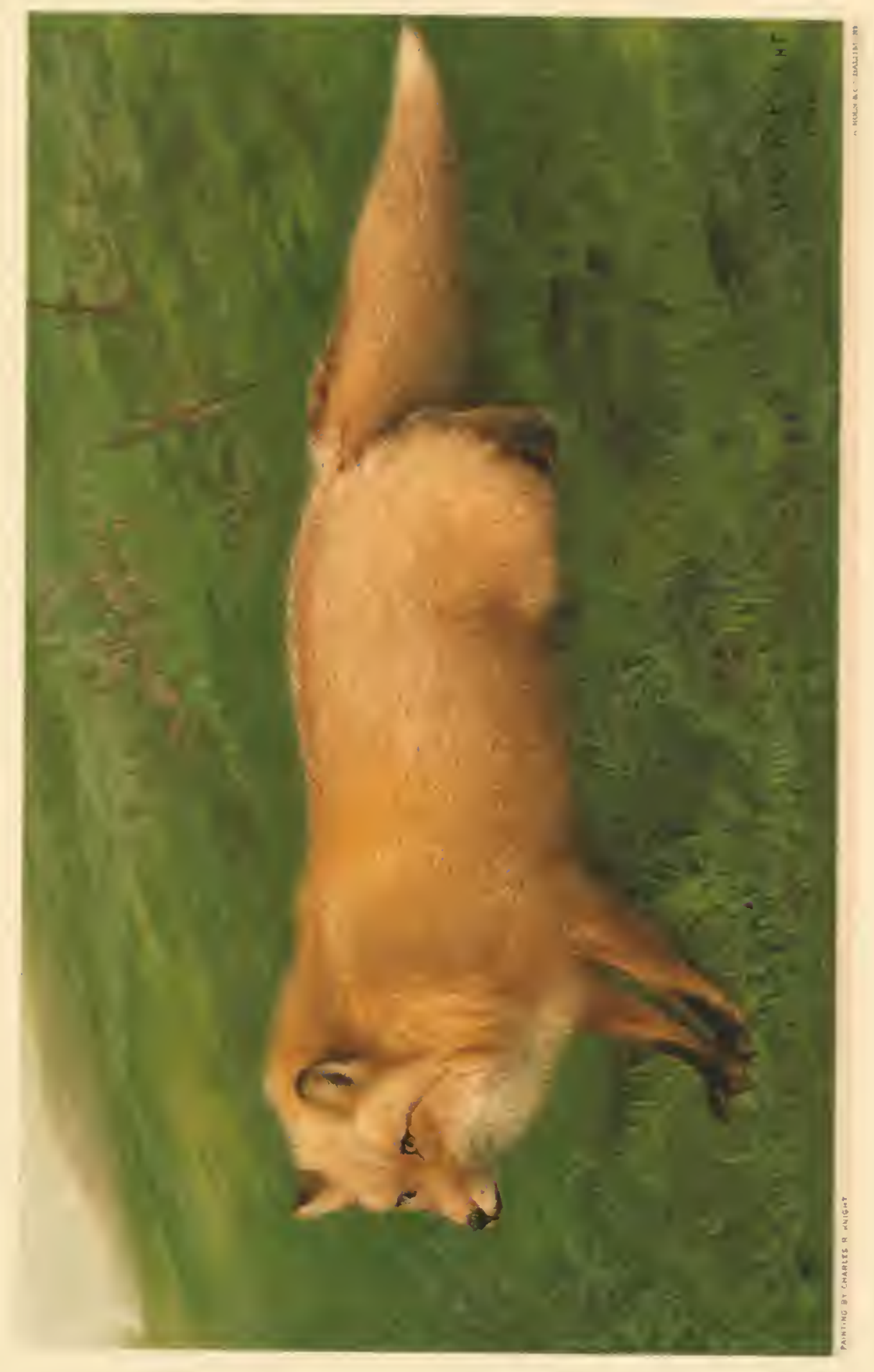


even to songbirds, the parks and other public properties in cities often support this wild life in abundance. To this awakening interest in the preservation of animals is now added the desire to preserve the wild flowers.

This desire to protect and preserve our native animals is well expressed in President Roosevelt's reference to the subject when discussing the forest preserves in his message to Congress: "Certain of the forest reserves should also be made preserves for the wild forest creatures. All of the reserves

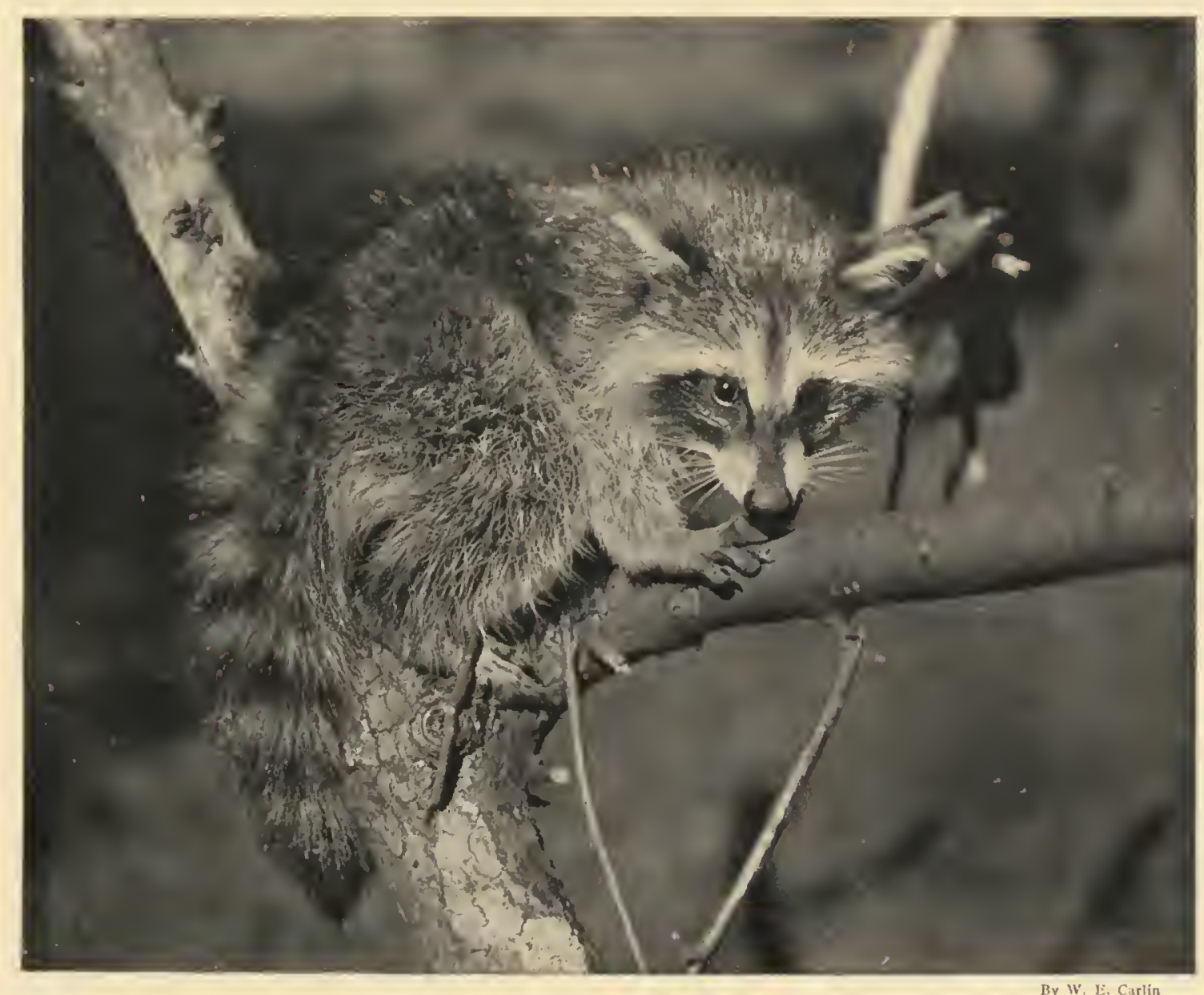

A RACCOON

should be hetter protected from fires. Many of them need special protection because of the great injury done by live stock, above all by sheep. The increase in deer, elk and other animals in the Y'ellowstone Park shows what may be expected when other mountain forests are properly protected by law and properly guarded. Some of those areas have been so denuded of surface vegetation by overgrazing that the ground-breeding birds, including grouse and quail, and many mammals, including deer, have been 
exterminated or driven away. . . . In cases where natural conditions have been restored for a few years, vegetation has again carpeted the ground, birds and deer are coming back, and hundreds of persons, especially from the immediate neighbourhood, come each summer to enjoy the privilege of camping. Some at least of the forest reserves should afford perpetual protection to the native fauna and flora, safe havens of refuge to our rapidly diminishing wild animals of the larger kinds, and free camping grounds for the everincreasing numbers of men and

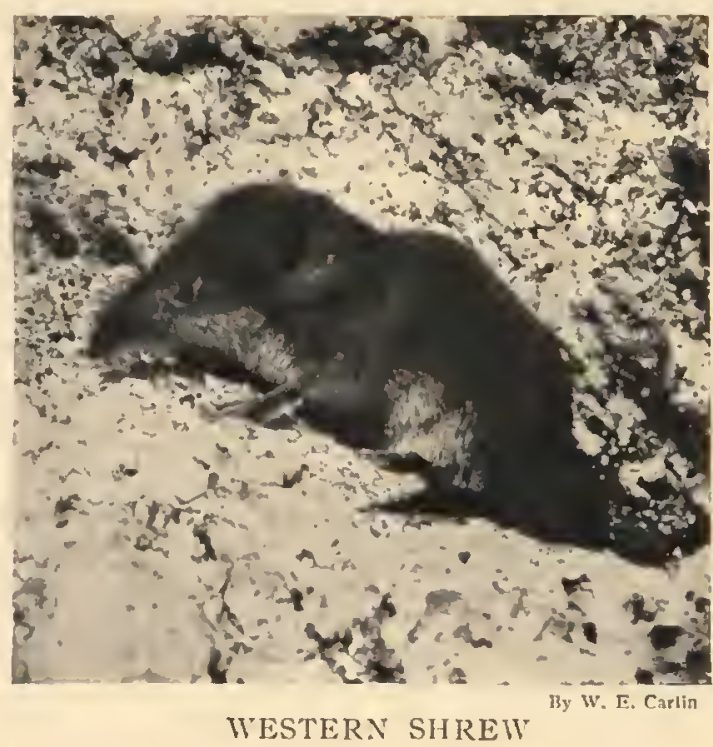

Photographed in the Bitter Root Mountains at an altitude of 8.500 ieet The party found him crossing a large rock and by surtounding him, mad women who have learned to find rest, health and recreation in the splendid forests and flower-clad meadows of our mountains." The enlargement of our sympathies is also well reflected in the many societies that aim to lessen cruelty to animals.

Hunting to kill is not necessarily cruel. The best hunting is that which kills quickly. The poorest-for both the hunted and the hunteris that which prolongs the struggle. Nature herself could be indicted for cruelty were not her practices dictated by inevitable conditions; but this fact does not release man, who acts largely as a moral agent. In nature, many animals meet violent or tragic deaths. The bird of passage that cannot keep up with its fellows is caught by the hawk or owl. The weaklings and the stragglers are taken. Where are the graves of the unfit?

The practices of any age are but the expressions of the needs and motives of that age. Much of the hunting is dictated by the desire of profits in money, and these profits often depend on fashion. Mere fashion has been the cause of the practical extermination of species of birds. The demand for furs is leading to similar results. Many other species naturally perish before the continued onslaught of civilization, by means of which the native haunts are destroyed. It is inevitable that the animal creation, as a whole, shall recede as the earth is subdued to man. But too often this creation has fallen long before its time. All the foregoing remarks illustrate what we believe to be an enlarging spiritual vision respecting our own place in the world. 


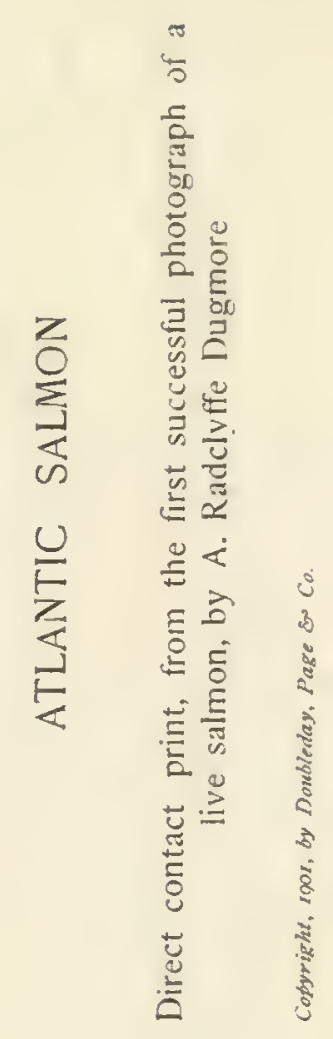





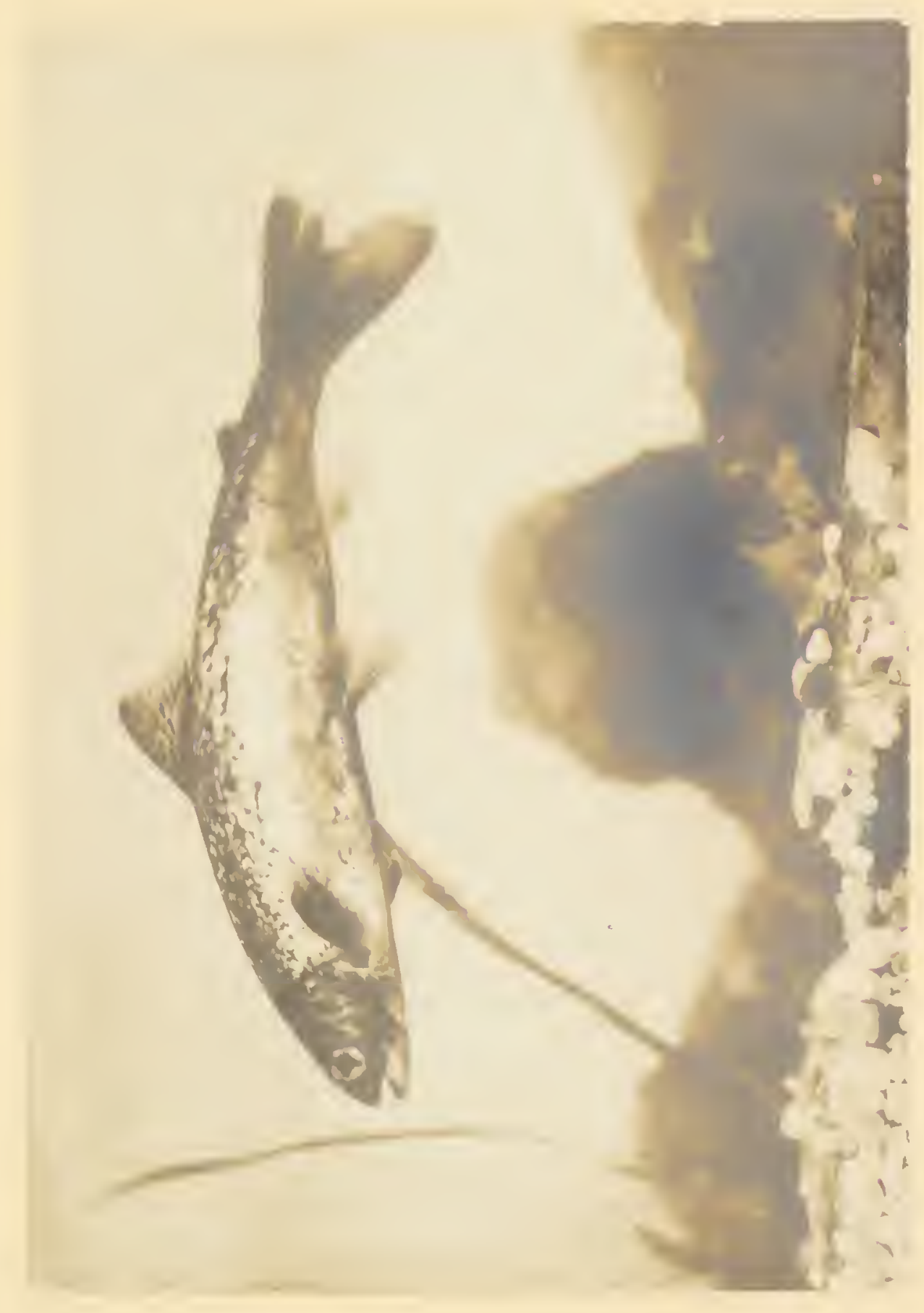




\title{
NATURE PORTRAITS
}

\author{
PAR'T II
}

MUST A "USE" BE FOUND FOR EVERYTHING?

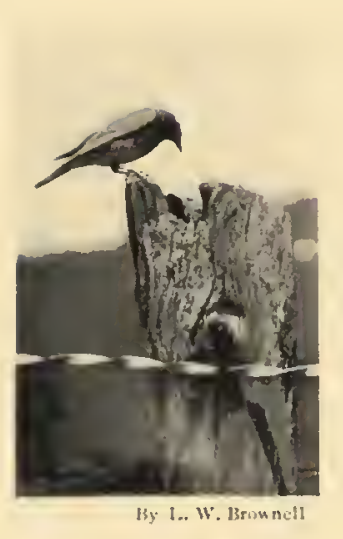

SPRING'S HARBINGER-

THE BLUEBIRD

EACH pupil had a plant of the spring buttercup. The teacher called attention to the long fibrous roots, the parted leaves, the yellow flowers; but these parts were apparently only incidentals, for she touched them lightly. But the hairs on the stem and leaves were important. They must be of some use to the plant. What is it? Evidently to protect the plant from cold, for does not the plant throw up its tiny stem in the very teeth of winter? It was clear enough; and thus are we taught that not the least thing is made in vain. Everything has it place and use; it is our business to determine what the uses are. We must think of these things as we come and go.

I wondered how these children would look upon the plants and animals they meet, and what the great round world would mean to them. The blackberry has thorns to keep away the animals that would harm it; the rabbit has soft short fur that it may not be caught in the briars; the poison sumac has venom to protect it from those who would destroy it; the crow is black that it may not be seen at night; the nettle has stings to punish its enemies; the dog fennel has rank scent to protect it from the browsing animals. All the world is as perfect as a museum!

I wondered what would happen if some inquisitive child were to ask what becomes of all the plants which have no thorns or hairs or poison or ill scent. What if he should ask why the thornless blackherry does not perish, or why the sumacs that are not poisonous still live, or if he should suggest that the dandelion comes up earlier in the spring than the buttercup and yet has no

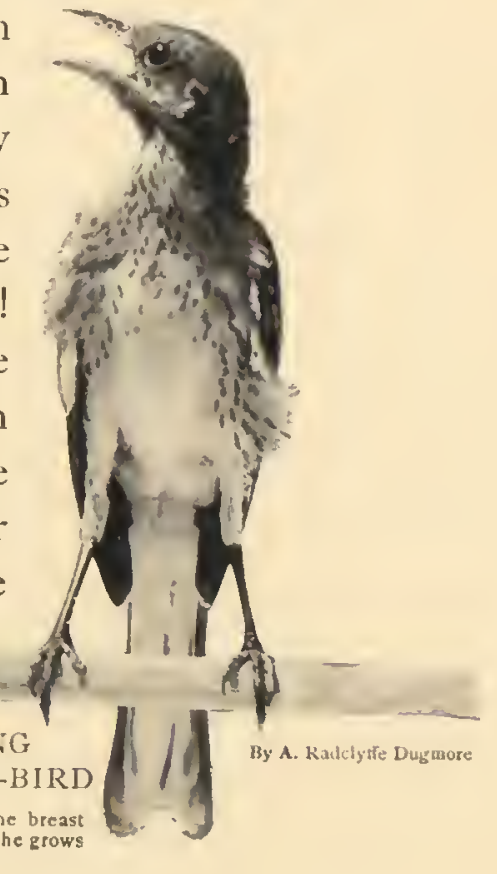




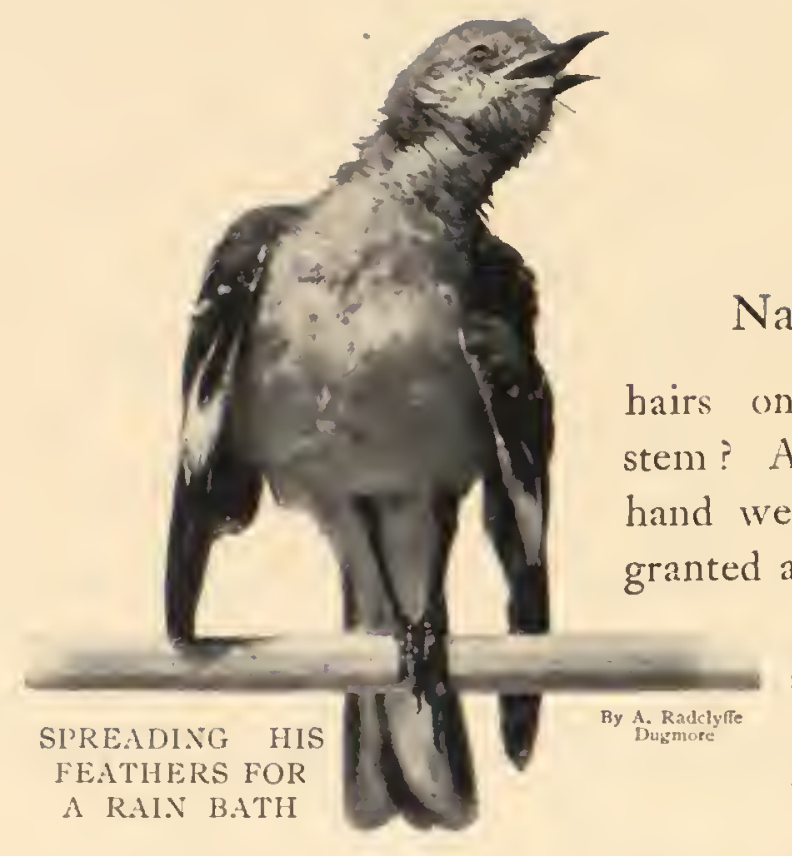

Nature Portraits

hairs on its slender flower stem? As I wondered, a little hand went up. The teacher ranted a question.

" Pigweeds ain't got any prickers," said the boy. I saw

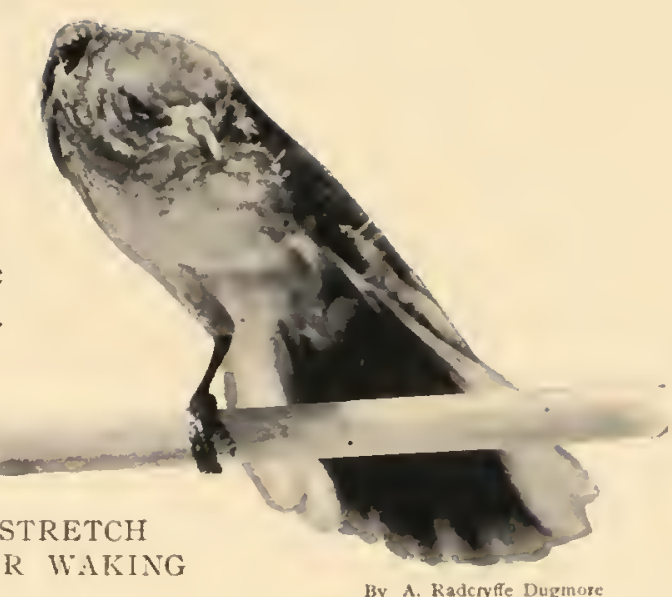

that the boy was a philosreplied the teacher promptly, something with which to

Thereby I knew her made up her mind what to to hunt until she saw it; like other persons. People for existence as a fight. It between adults. Everything armour. A botanist in writing strange plant, noted the marked: "That use to the plant doubted. Perprevent the acable insects."

Nothing thing; the only tion is true. I

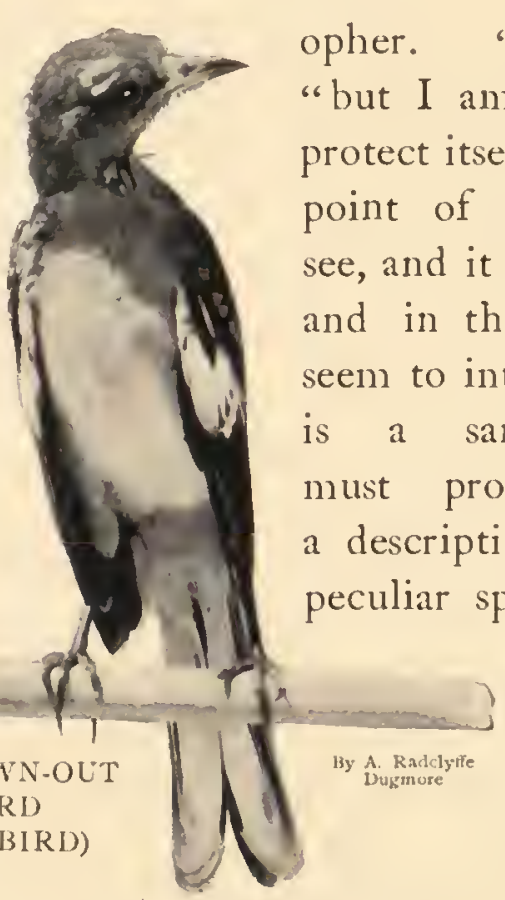

"True enough," "but I am sure that it has protect itself." point of view: She had ee, and it was necessary only nd in this respect she was seem to interpret the struggle is a sanguinary combat must protect itself with a description of a new and peculiar spines and then rethese are of some can hardly be haps they serve to cess of undesirSLIMI BIRD
(MOCKING-BIRD)

cess of undesir-

is easier than to find an explanation for anydifficulty is to determine whether the explana-

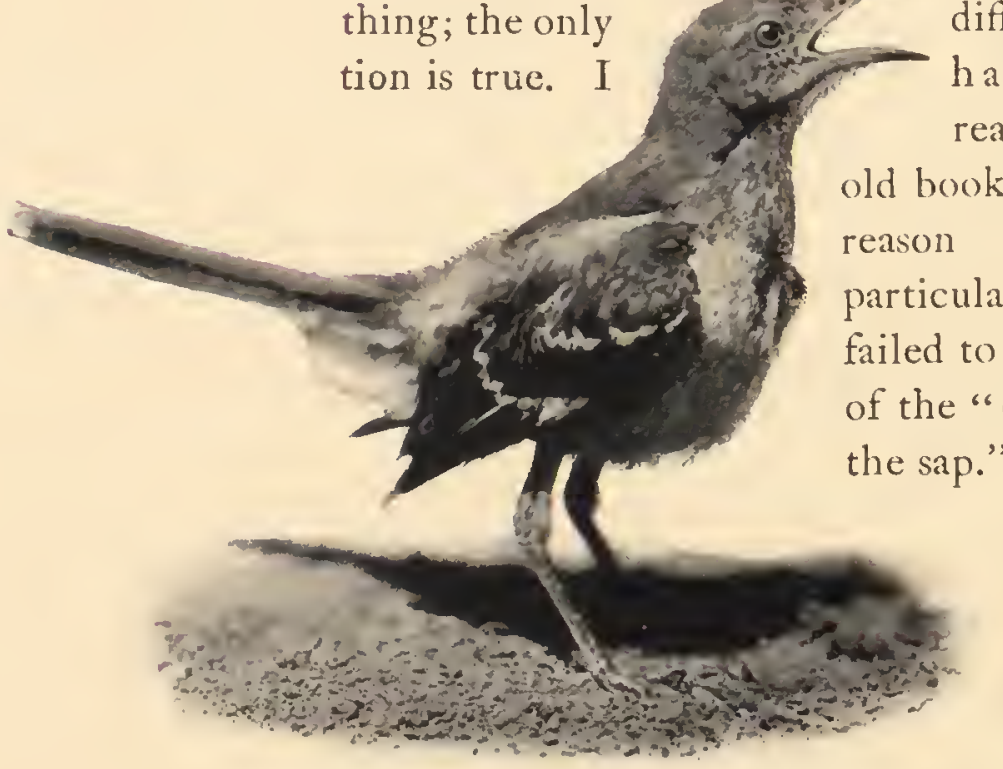

have just read in an ld book that the reason why a articular kind of graft failed to grow was because of the "disappointment of the sap." I laughed at the

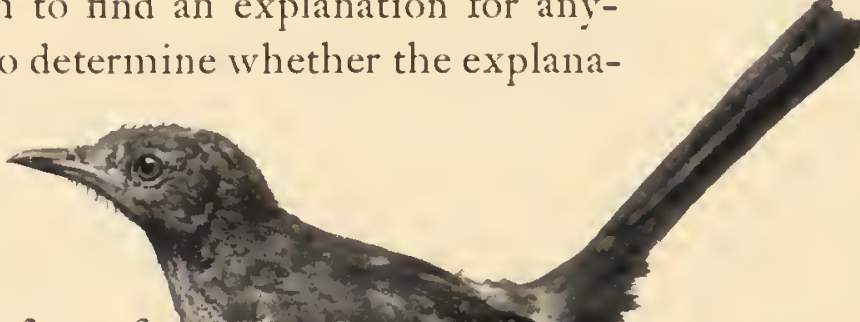




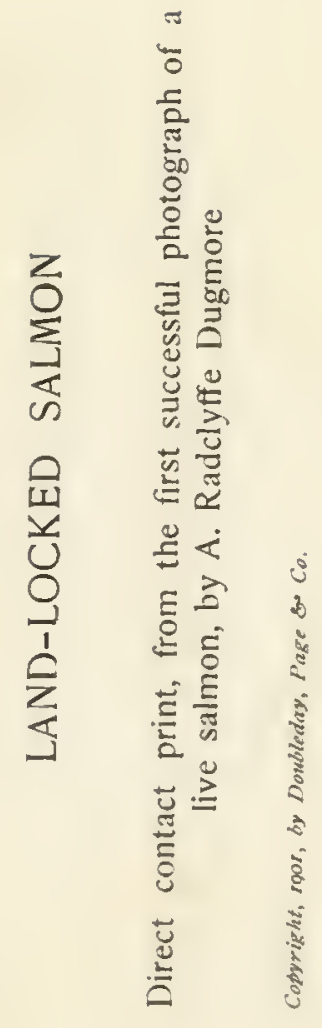





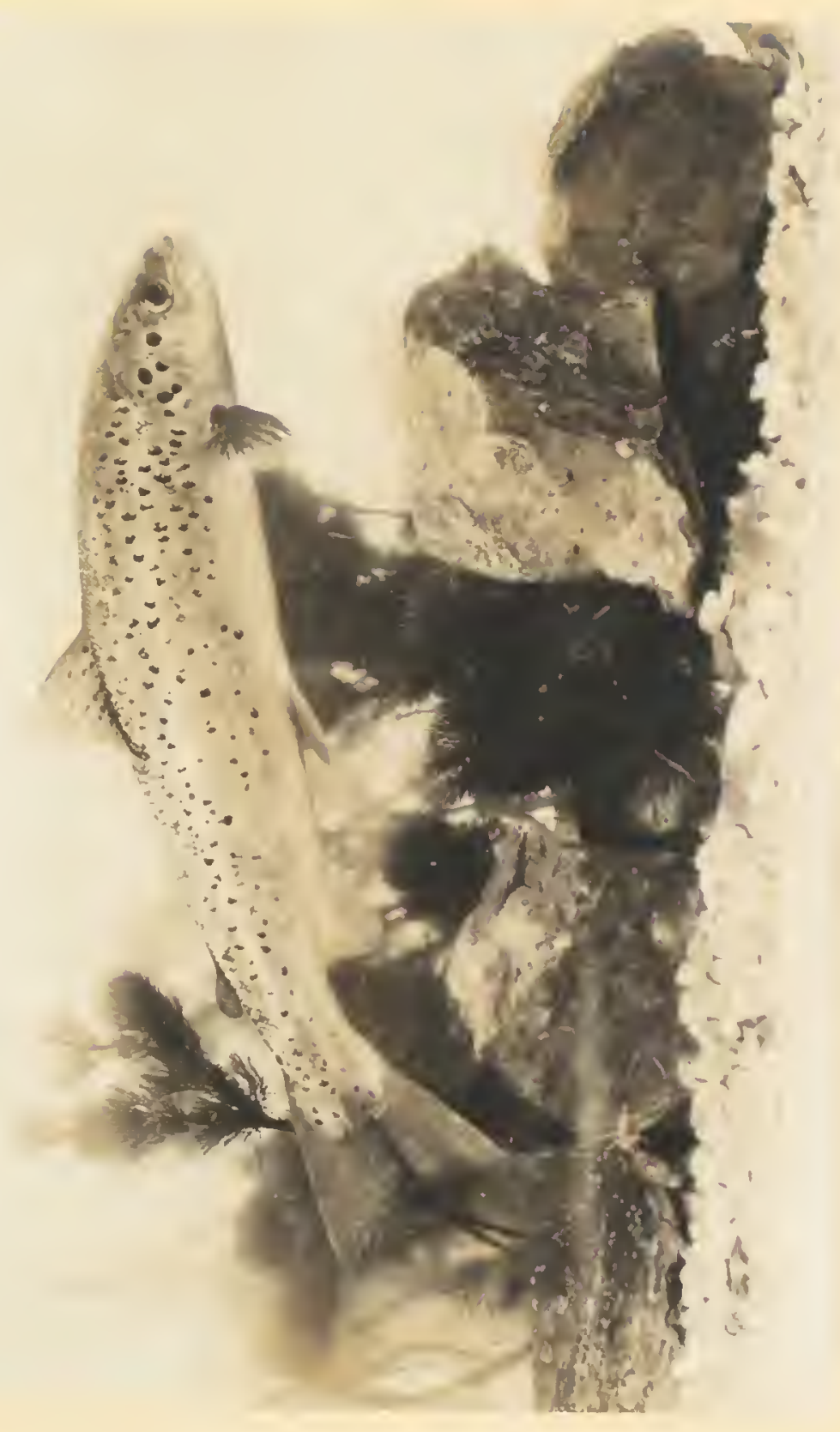


expression; and yet is it that the hairs exist to keep the sumac has poison to The teacher may as well Brown has freckles so that skin; and the statement

The other day a it is not true that the cacprotect it from browsing I did not know. I her, she wondered at wanted to know why told her that I had that an animal on a cactus. Perhaps

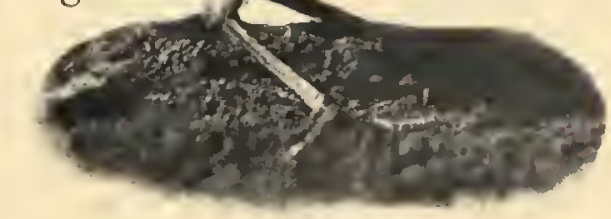

By A. Radelyfie Dugm

Just able to hy-and always hungry not as scientific as to say the crowfoot warm or that protect it from its enemies? have said that Jimmie the sun will not tan his would be hard to disprove. teacher asked me whether tus has spines in order to animals. I told her that being a stranger to my ignorance. She I did not know. I no good evidence wanted to browse the cactus spines are older than browsing animals. Perhaps there was some special condition or reason in geologic time. Perhaps the spines were in some way the incidental result of the contraction of the plant body, which contraction was associated with the necessity of reducing the evaporating surface in an arid climate. Perhaps a hundred things. She was surprised that I had to go into geologic time to bury my ignorance. She wanted cause and effect side by side and in the present. Then she could see them. It is a bother to look for causes behind.

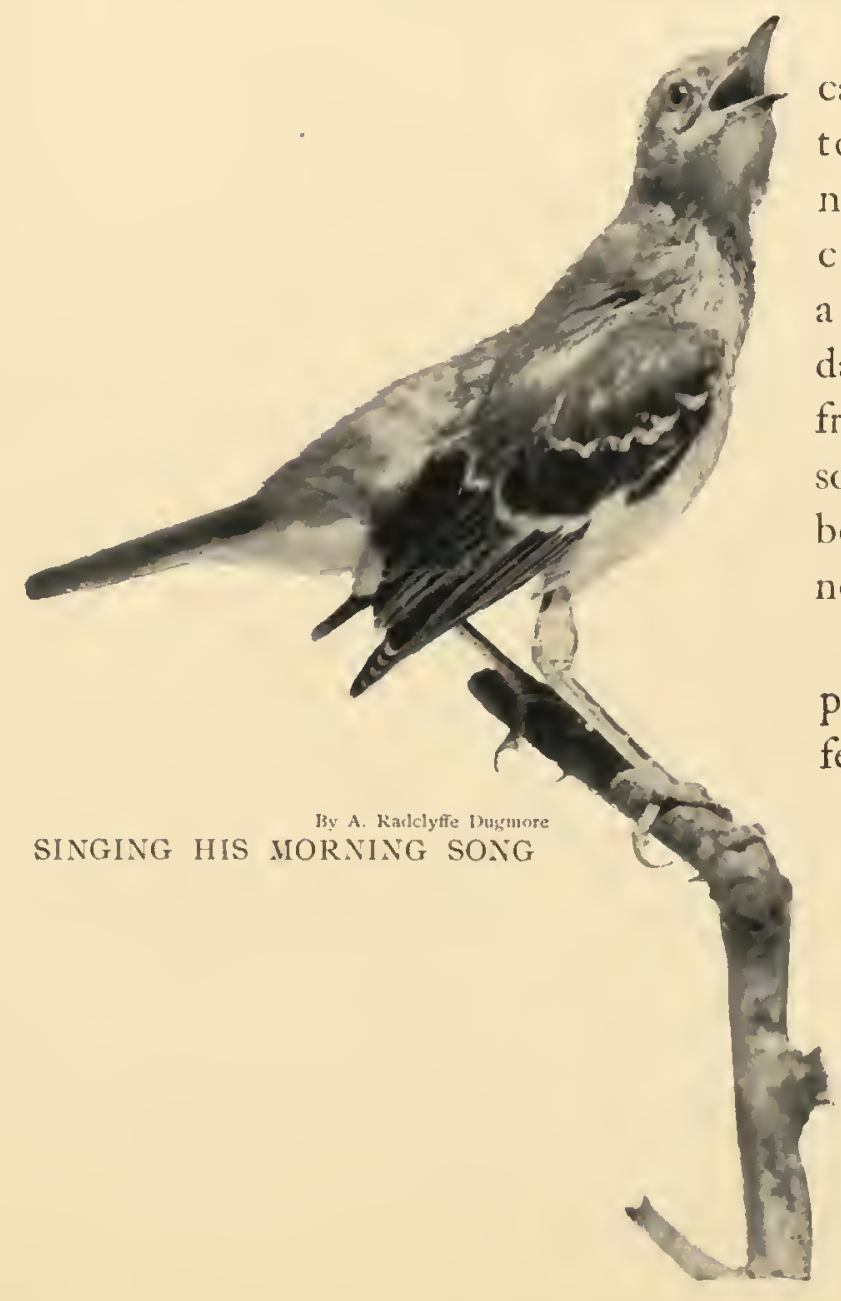

This is a typical case. This attitude towards nature comes al most

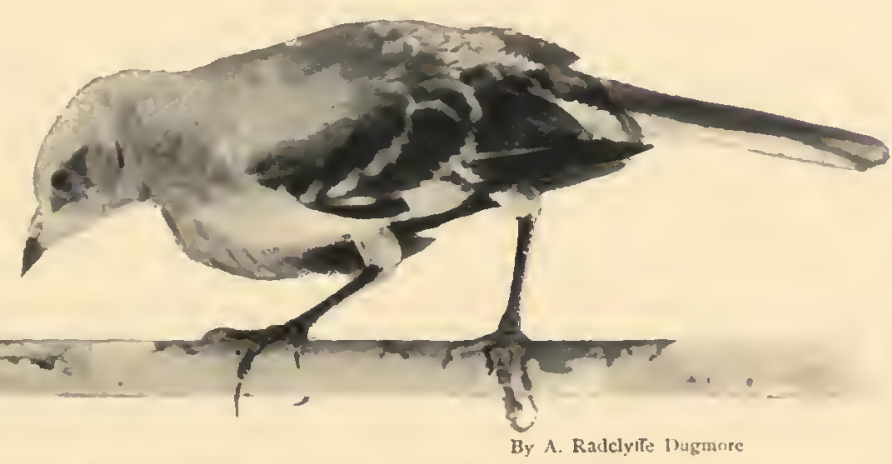
daily to the teacher; in fact it sometimes comes from the teacher. The mischief is increased by some popular books on science, and some of these books have been written by persons who have done noble work for truth.

This is one of the greatest faults with the popular outlook on nature,- - the belief that every feature of plant or animal has a distinct use in the 


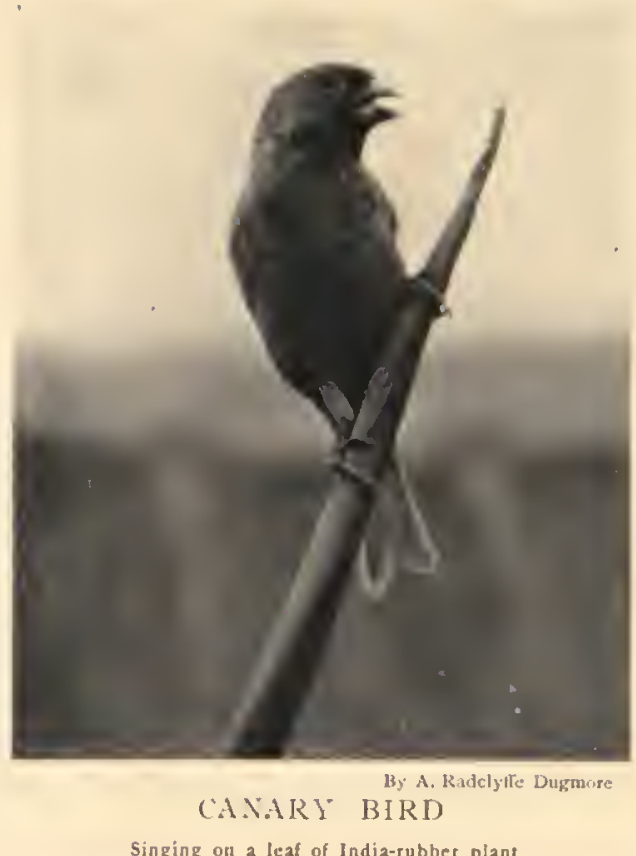

present time and that one has only to look to see what that use is. People often look at the little things and riniss the big ones. They look for the hairs and miss the plant. They see the unusual and rare and overlook the common. I wish that people might learn to see dandelions.

Having seen a thing of which the function is not evident, they assime a condition and jump at a conclusion. A plant has poison; various creatures eat plants; the creatures are killed by poison; therefore the plant has poison to protect itself from the creatures. Now, it may even be true that the poison does protect the plant, but there is no proof thereby that the poison was produced for that purpose. The physiologist may find that the poison in the given case is merely a waste product of some chemical metabolism, and that the plant is fortunate in getting rid of it. If the plant is now and then protected, the result may be only an incident. If it should appear that one kind of plant, by natural selection, has developed poison in order to protect itself, the fact would be spread abroad in book and magazine, but it would not be stated that it was one case out of a thousand. The exception is enlarged into the rule. People like to write about perfect adaptation of

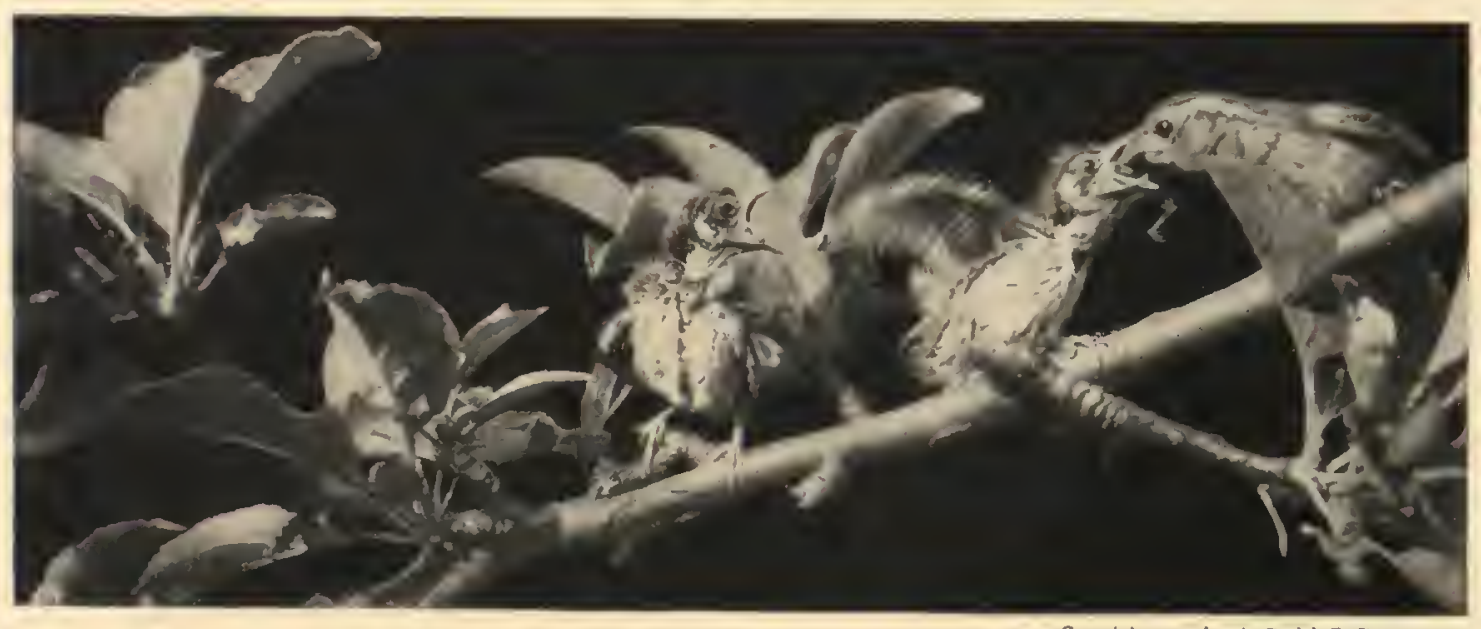

ANXIOU'S FOR HIS TURN

Copyright, 19:0, by A. Raulclyffe Inummore 


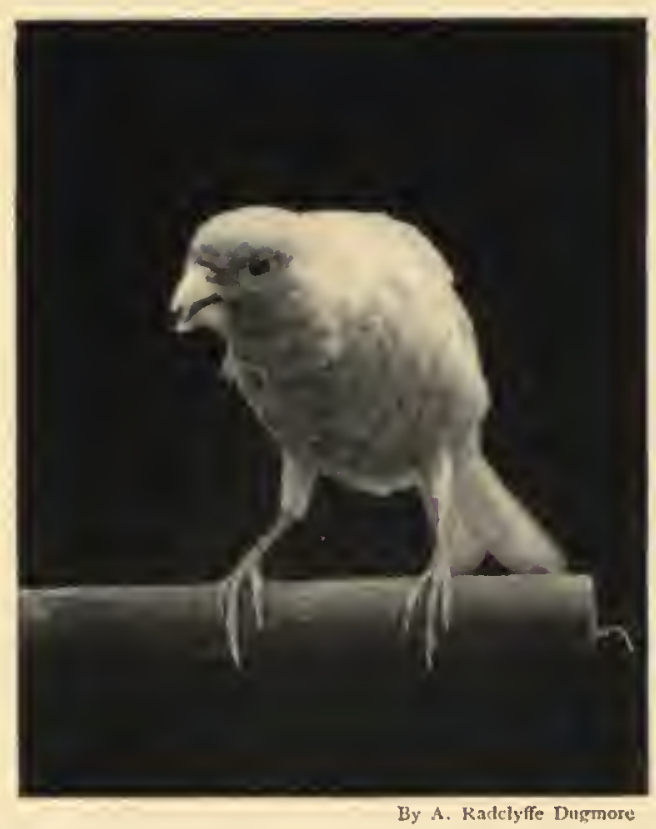

means to ends, without a slip or break in the process. A teacher brought a Hower and asked what mechanism it had to ensure cross-pollination. I told her that I was not aware that it had any; and she was surprised. I wish

A YELLOW CANARY BIRD SINGING

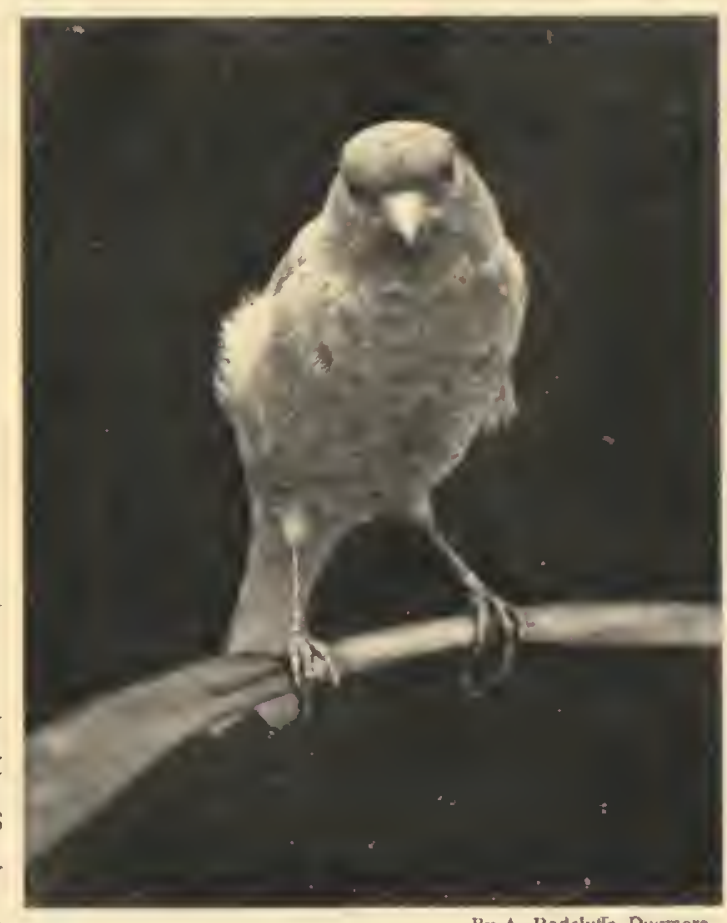

CANARY BIRD On a leaf of India-tubber plant significance in the development of this

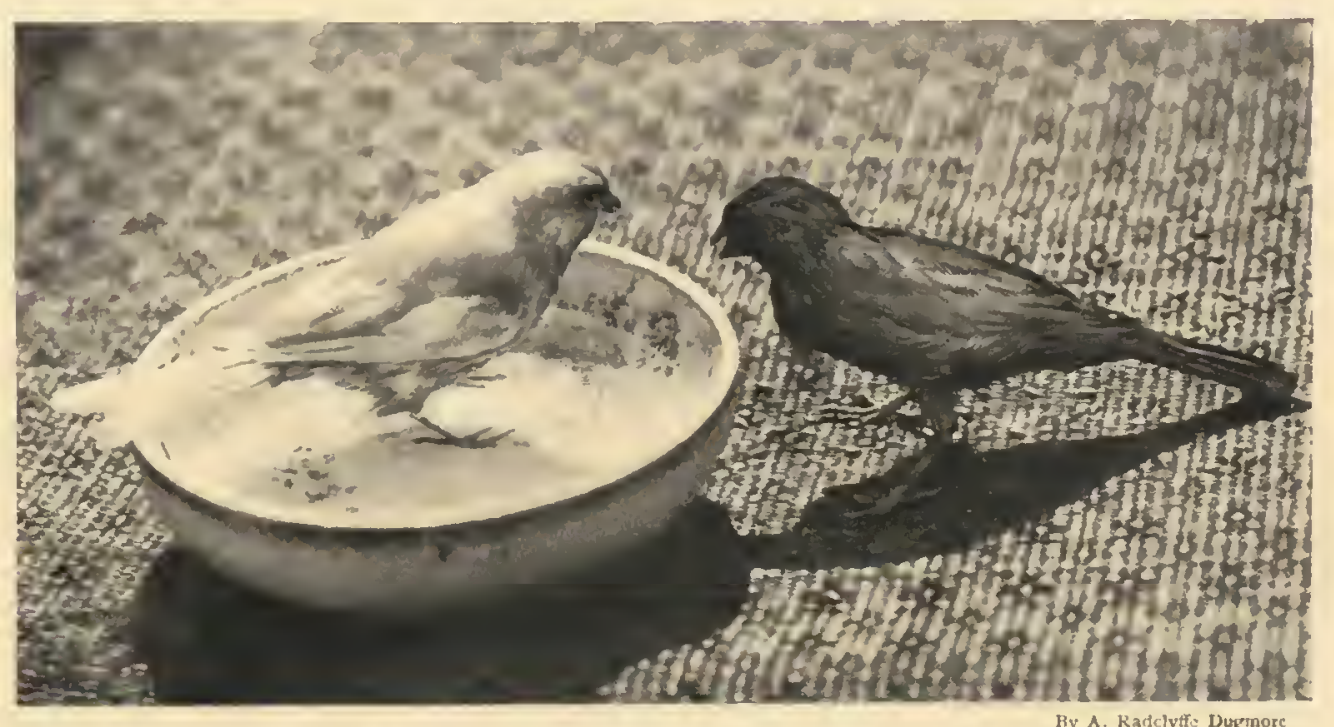

A YELLOW CANARY BIRD TEACHING ITS MATE HOW TO BATHE 


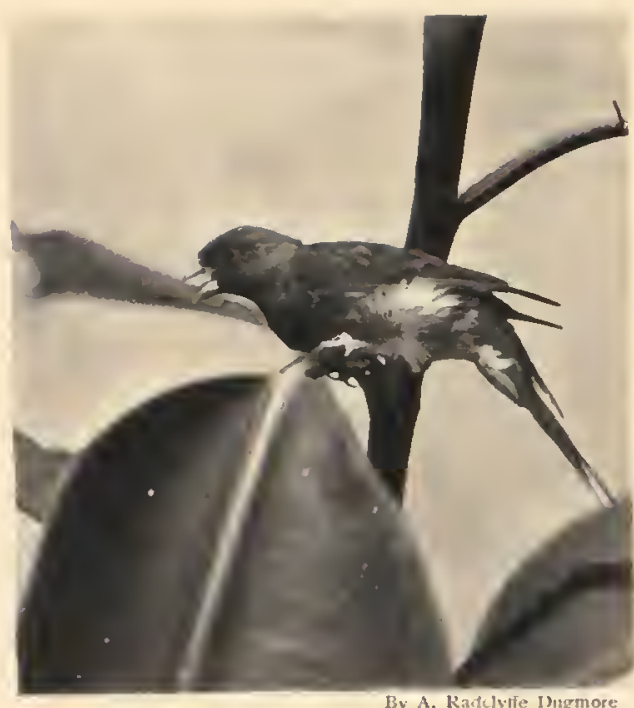

I SIIY GREEN"BROWX゙ CANARY BIRI A cross between an Austrian and a Belgian

because of natural selectionbecause they were best fitted to persist. The result, in many things, is perfect adaptation of every organ and attribute. 'There followed a special literature on adaptation and mimicry and the

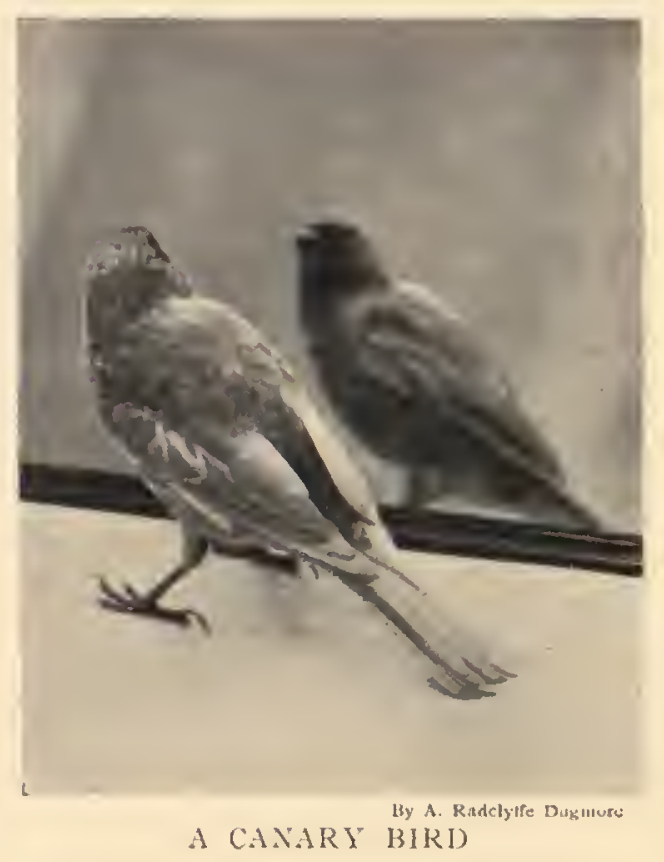

A CANARY BIRD Coming face to face with its own image in the mirror particular race? And he sets to work to find out. He cannot find out as he rides by on his horseespecially if he rides a hobby-horse.

Truth is, this everything-has-ause dogma is in part a reaction from the teaching of Darwin and his followers. People want to believe in definite, final, set things. 'The dogma of special creation was overthrown. Things have persisted

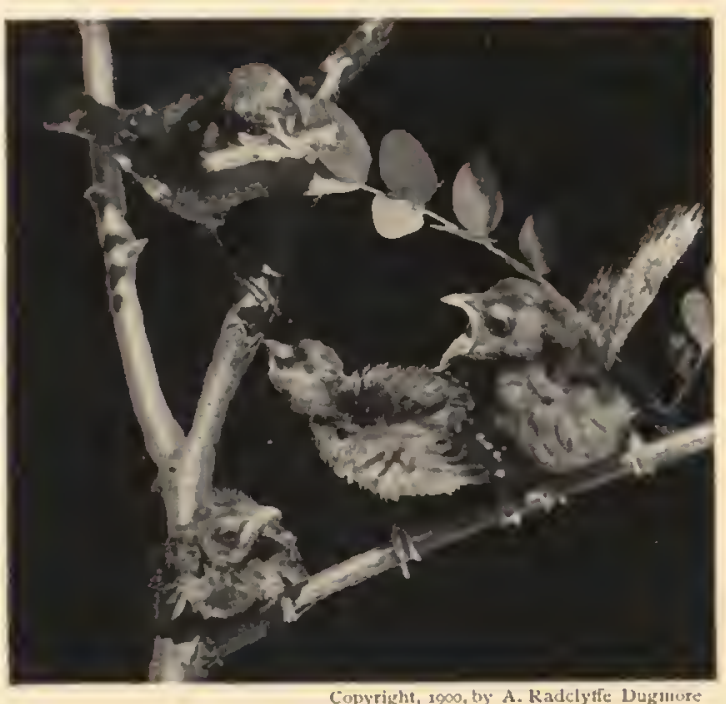

ONE AT A TIME

old and young Indigo birds

like. The examples may all have been true, but one result has been to lead persons to look for adaptations and mimicry where there may be none. What did it matter if there is no special creation ?-there is complete and universal adaptation, and our notions of what ought to be are verified.

But, someone will say, if there is natural selection and survival of the fittest, adaptation must follow 
|| 



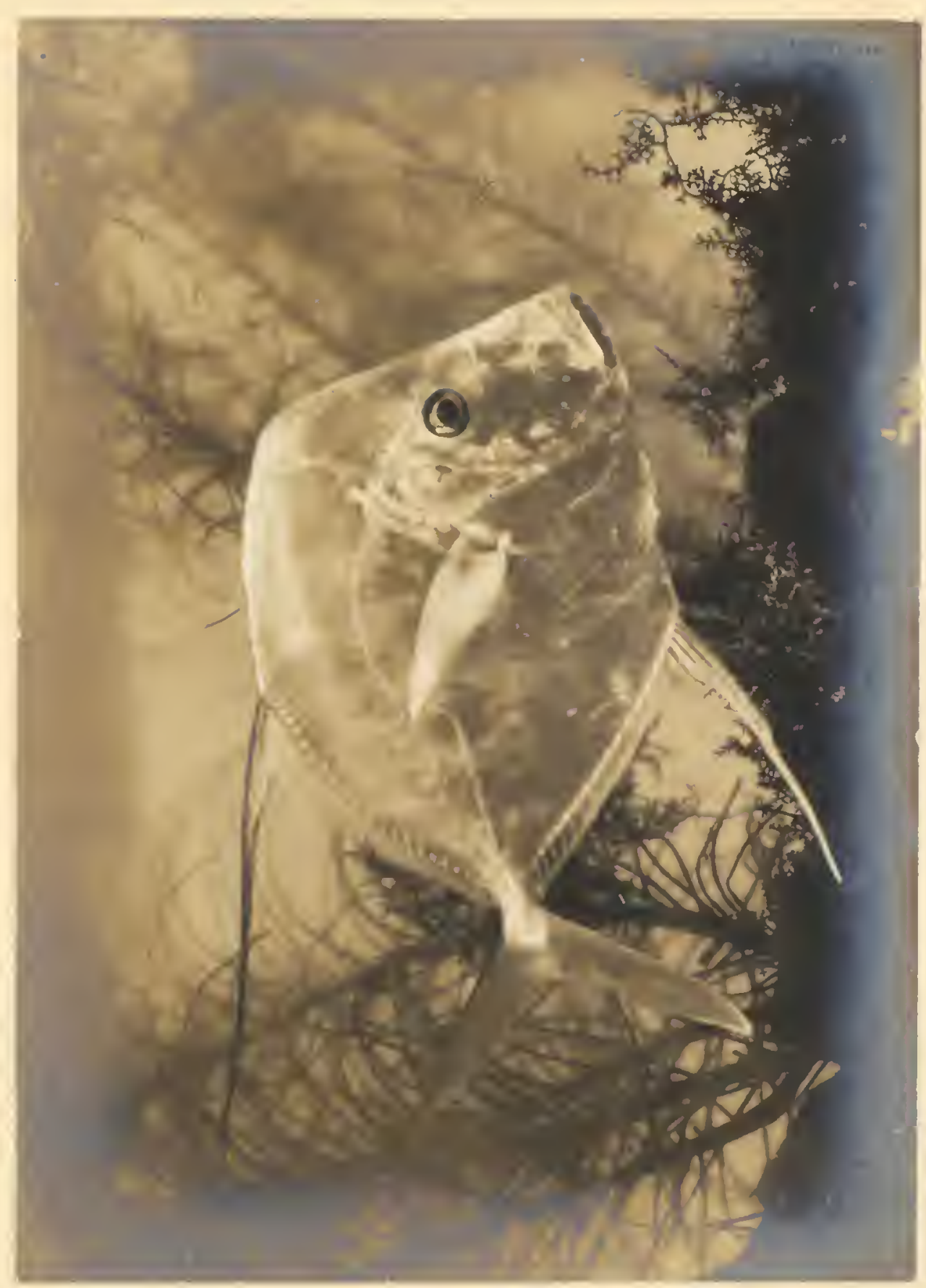





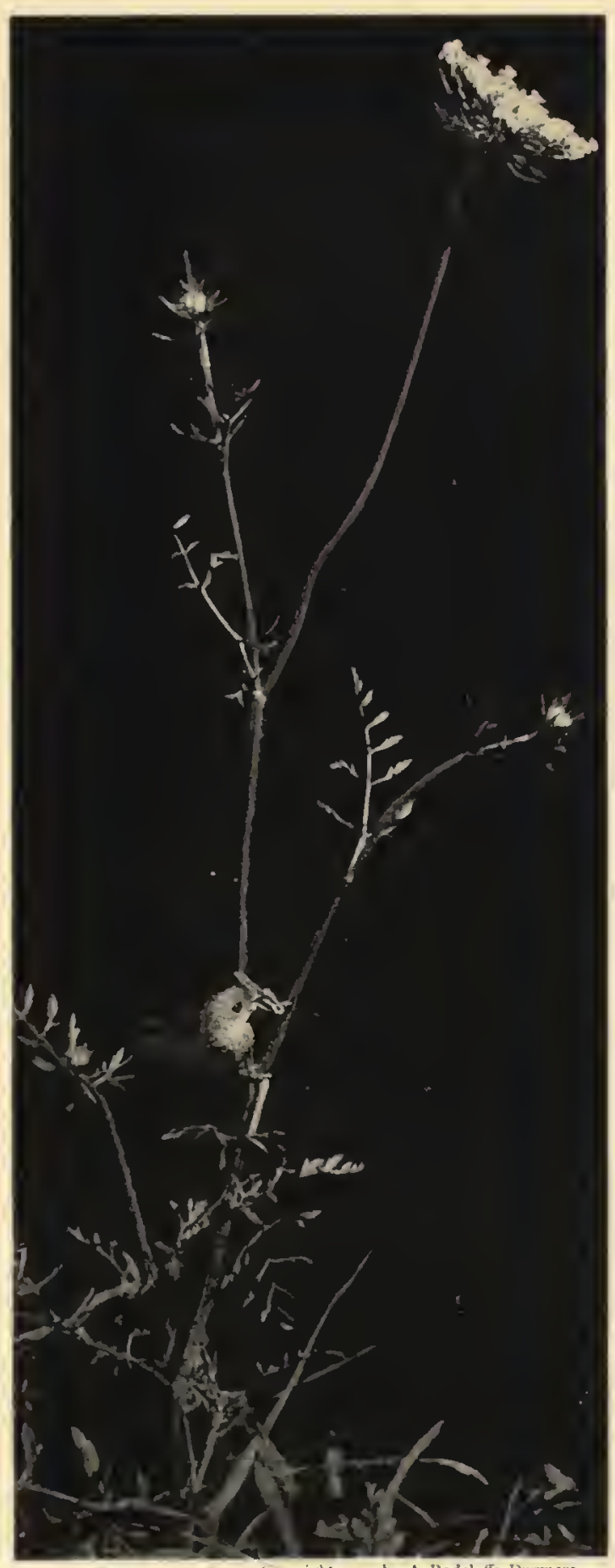
BRINGING HOME PROVISIONS

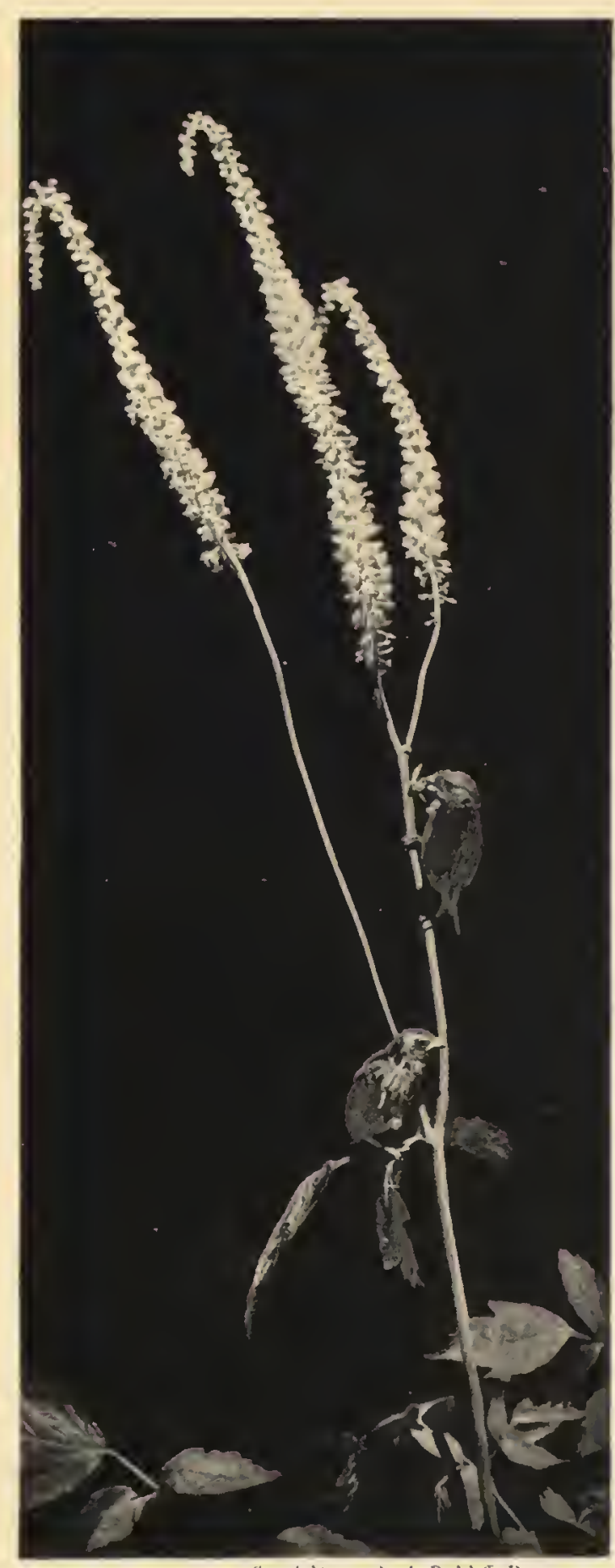

THE SAME INDIGO BIRD 


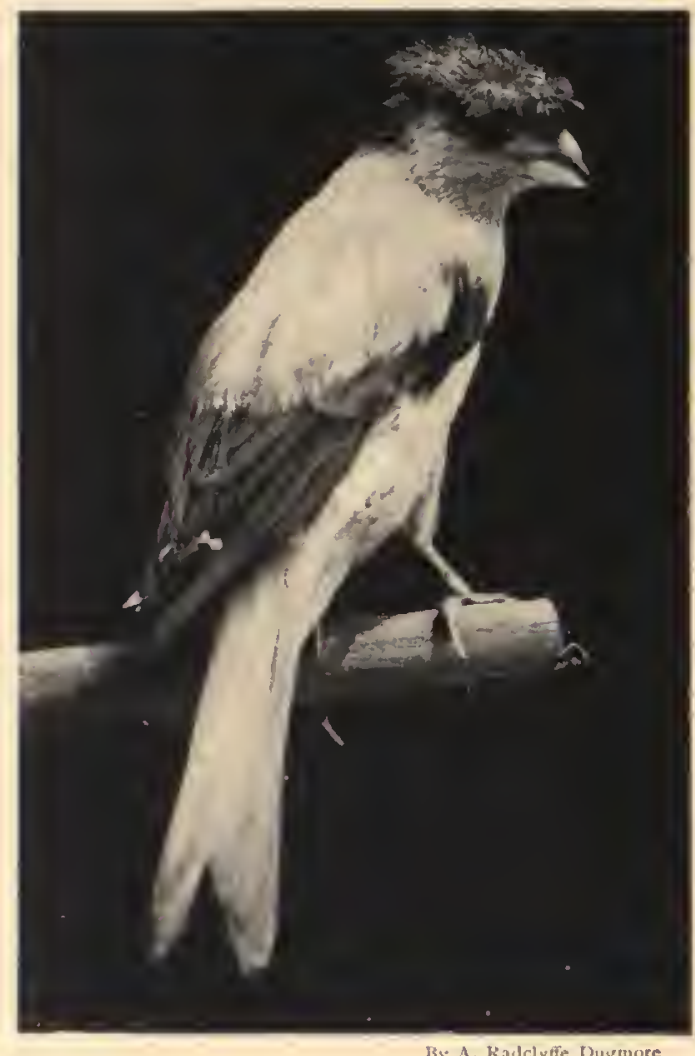

A TOPKNOT CANARY

as a consequence. Yes; but it does not follow that every part or feature of the organism is specially adapted. A strong feature may carry other features which are merely innocuous or even harmful, as a horse carries a rider; and then, if unfit features tend to pass away, these features are misfits until they have disappeared.

\section{U T I L I T Y}

In deepest wood

A flow'ret stood

'Neath unknown skies.

Its petals bright

Ne'er gave their light

To human eyes.

A wand'ring man

'Neath learning's ban

Espied the flow'

"Ah, little swain

Thy life was rain

Until this hour.

But Nature knew

Of all that grew

No thing was vain,

The restless tease

Of busy bees

Had render'd gain.

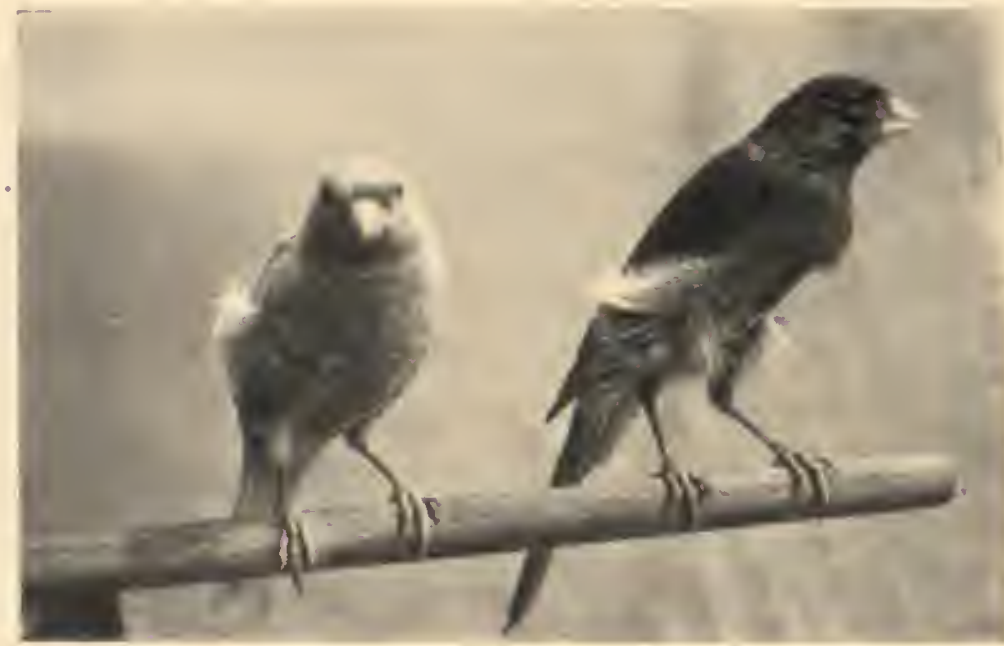

A YELLOW AND A GREEN-BROWN CANARY 


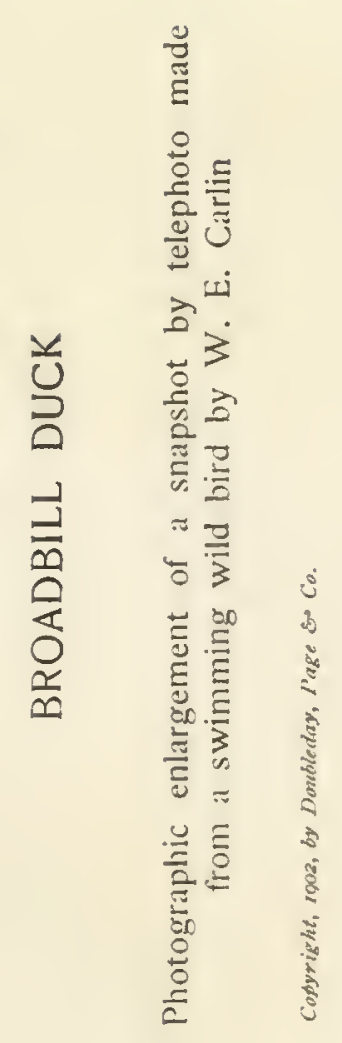





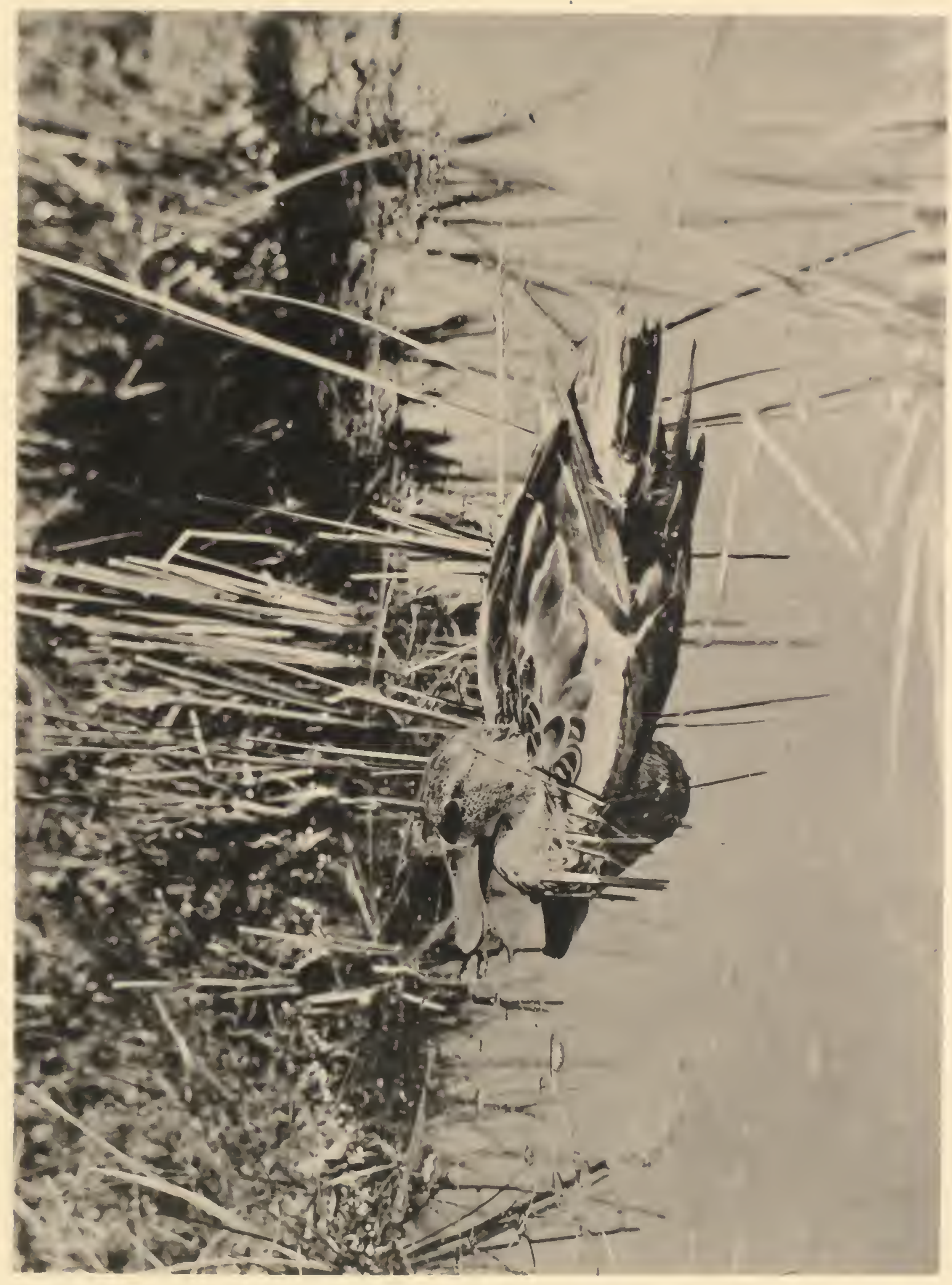




\title{
NATURE PORTRAITS.
}

\author{
PAR'T III.
}

SCIENCE FOR SCIENCE'S SAKE.

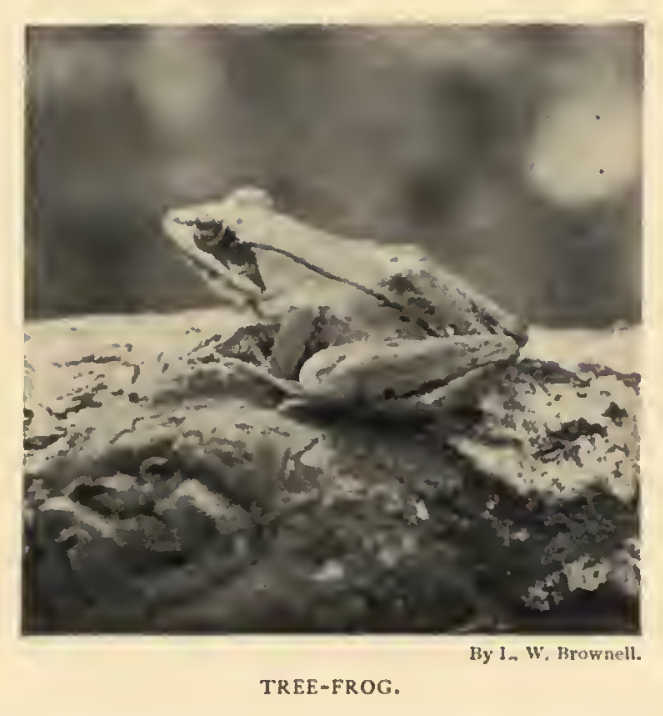

in the fields and picked a dandelion.

But there was a man in the audience who squelched the little woman. Her methods were all wrong. They were worse than wrong: the children must unlearn what she had taught them. She should have begun with some definite subject, and followed it systematically and logically. The pupil must be held to the task day after day, until he masters the topic. To skip from subject to subject is to be superficial. It does not result in mental drill. To make a collection is only play, and names are vulgar. The pupil must be impressed with the immensity and importance of his subject. When he was talking, I smelled alcohol and I saw a frog in a museum jar.

Which was right? No doubt each was right from the personal point of view, but wrong from the other's point of view. I recalled that the little woman only recited what she had done; the man had upbraided her for not doing something else. Perhaps it is easy to advise and to criticize. The little woman was teaching children. She wanted to lead them to love the things they saw. She approached the subject from the human side, for are not the boy and the girl a part of what we call nature? They are not yet 


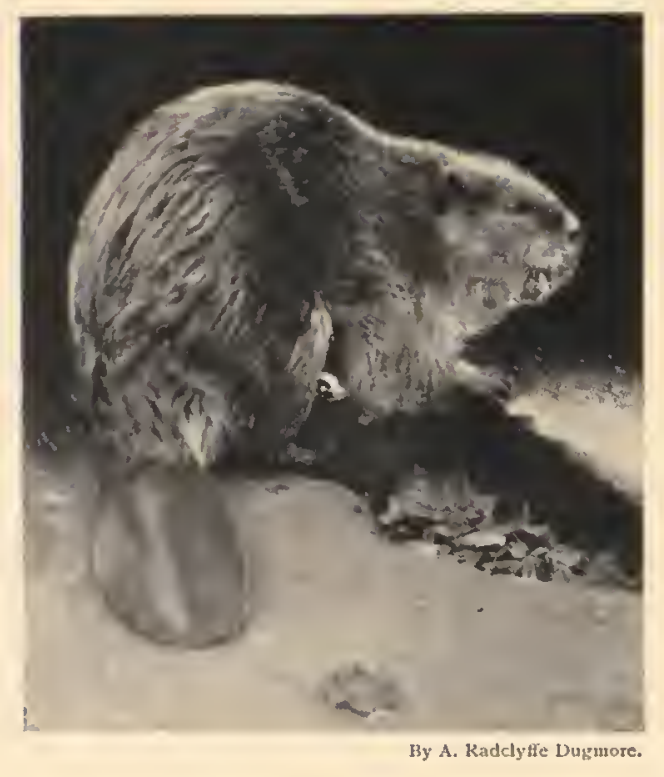

BEATER,

tamed and conventionalized. Does not every boy and girl like to go in the fields and to "get" things? She was not thinking of the subject-matter; or if she did think of it, she knew that it can take care of itself. All she was thinking of - poor soul! — was to interest and educate the children. And she knew that if she set a subject and followed it day by day, the seats would soon be vacant.

The man was thinking of his college students; perhaps he had not considered that these students already liked the subject and needed only instruction. He forgot that you cannot force a person to choose a thing, although you may force him to take it. His were picked students, one from this town and another from that; hers were all the pupils in her little community. His pupils had seen and had chosen; to hers the world was all unseen and untried. His were the one in a bundred; hers were the entire hundred. His students had chosen the subject ; for this subject they were to live; they would increase the boundaries of knowledge; they would be scientists. He did not consider that all pupils should not be scientists.

Sometimes it seems as if scientists think that they have the right of way in the subjects which they espouse; but there is more than one way of interpreting nature. Their view is necessary in all matters of fact and truth, but not when points of view are concerned. This is well illustrated in the usurpation of common words. The word "organic" relates to organisms and their products. But when the chemist studies the composition of organic compounds, he defines the word in terms of chemistry. To him an organic compound may be a carbon compound or a carbohydrate derivative, and he can make an organic compound without any relation to an organism! Organic is originally a biological, not a chemical idea. Again, our forefathers used the word "bug" for any kind of a bug; but scientists have taken this word "bug" and have made it mean only a particular kind of bug. This were all well enough amongst themselves, but when they attempt to make all the rest of the world use "bug" as they do, they go too far. Our forefathers have prior claims. It would be better if newly made words could be used for new ideas. Science needs a technical language of its own. 


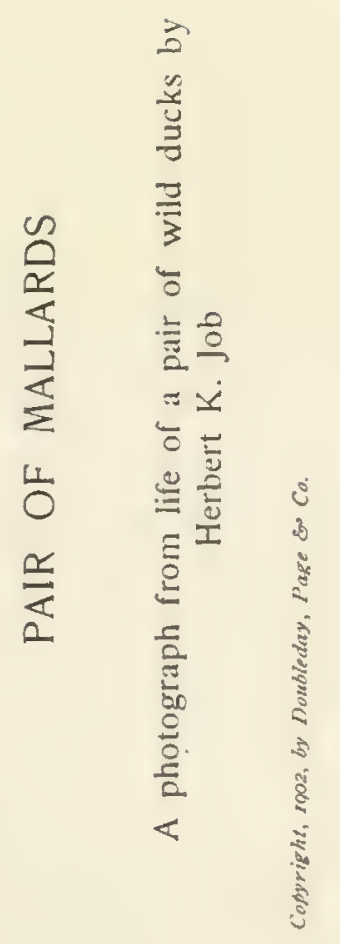





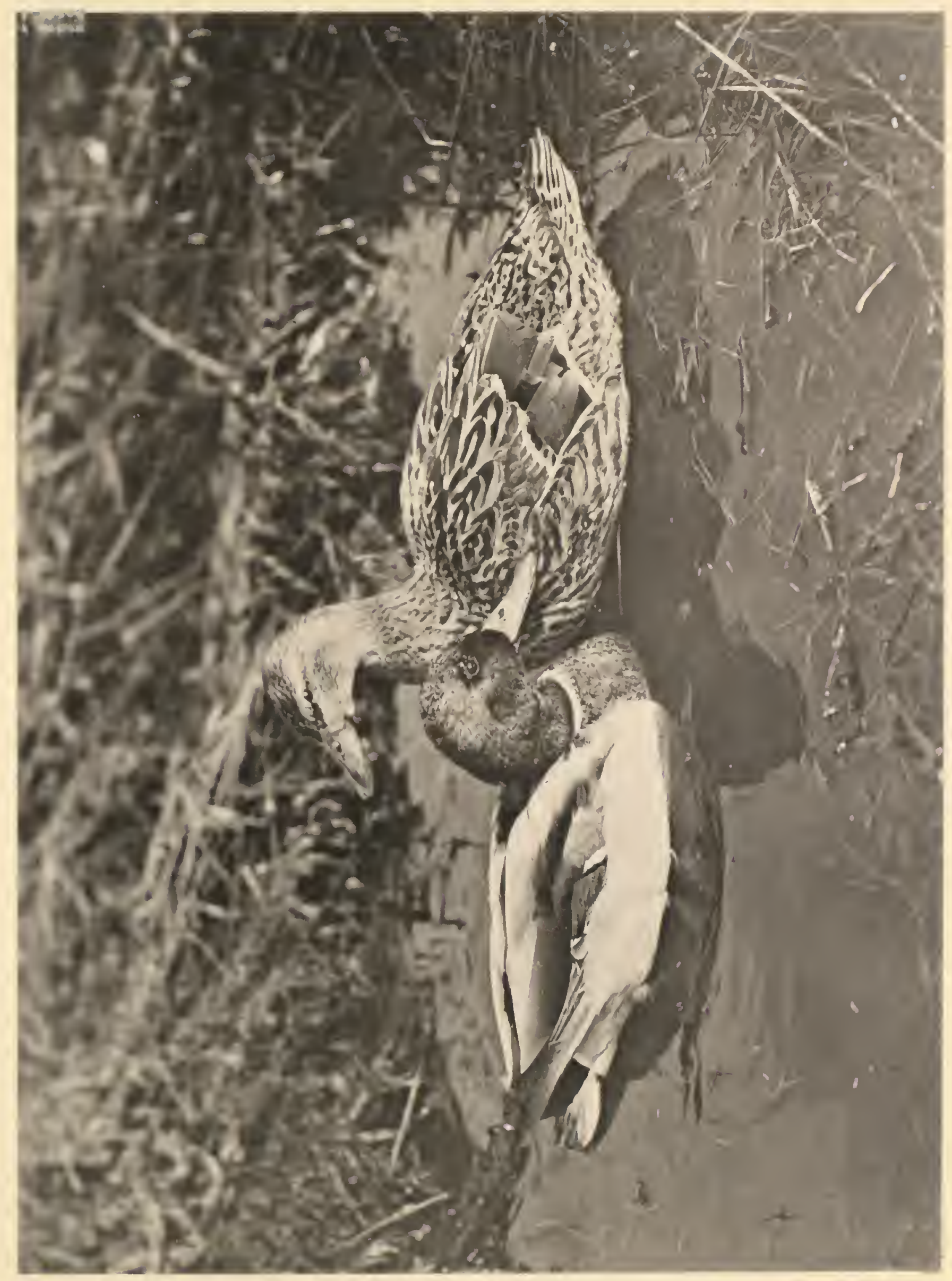





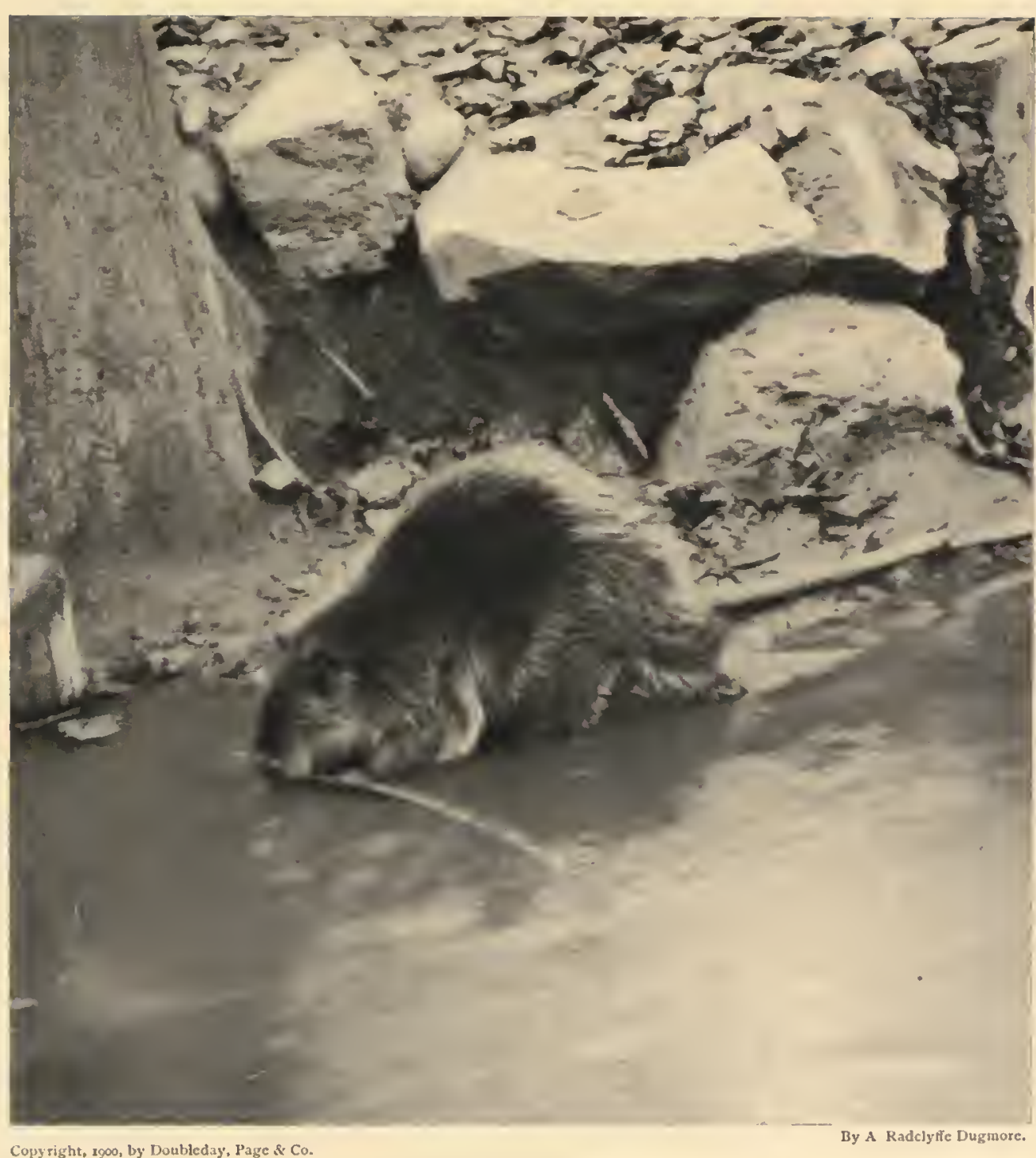

BEAVER AT WORK.

What is the kernel of all this discussion about the pedagogical sin of making collections and of attaching names thereto? The old idea of the study of nature was to make an inventory of things. The things were bewilderingly numerous, and to put them away in a cabinet, with a proper ticket attached, was to know them. The great thing was names and classification; and these names must be arranged in books. This natural history bookkeeping received its largest impetus from the binomial method of naming, which might be called a system of "double entry."

This naming of things was necessary. It is the starting-point, as a city directory is. But it is only the beginning of wisdom. It is not an 


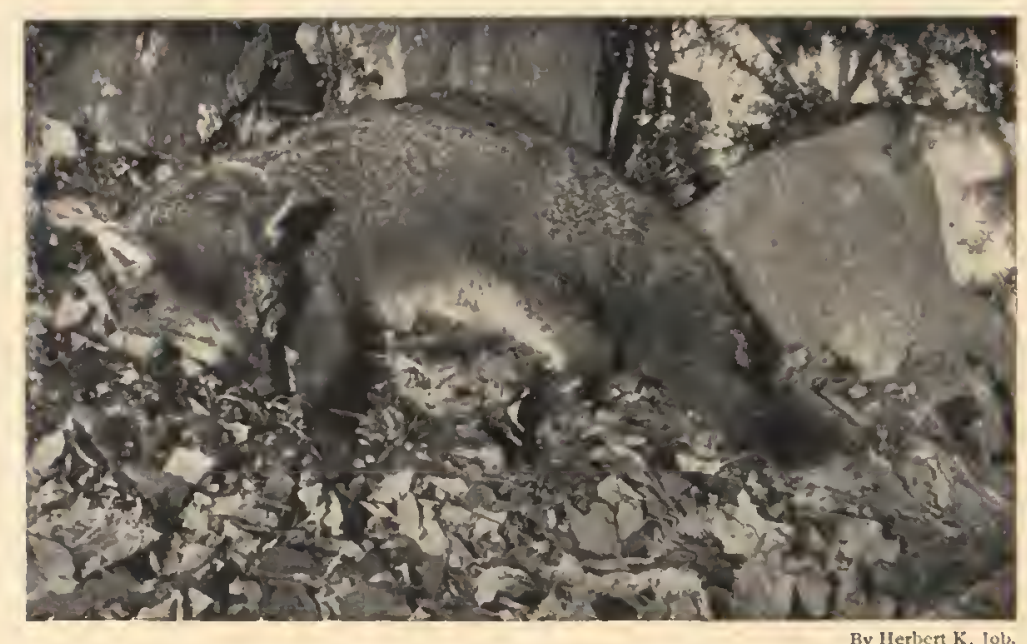

end. The profound speculations of the modern evolutionists have emphasized the importance of the things themselves, and particularly of real or live things. The point of view has changed. Do not let your pupils make an herbarium, the modern teacher will say, but tell them to A GRAY FOX ASLEEE. study the plants. We all sympathize with this point of view; but what are we going to do with this native and exuberant desire of the child to explore and to collect? We are taught, also, that we should develop and strengthen the natural powers. One of my friends will not let his little boy make an herbarium, because that is mere superficial amusement ; so the child collects postage-stamps. He does not care to have him know the names of plants, but he is very careful to have him properly introduced to visitors; and what is an introduction but a conventional passing of names?

I believe that we have gone too far in decrying the making of collections. We can make the collection the means of securing real information. We can fasten the attention of the child. The one caution is, not to make it an end. The child cannot collect without seeing the thing as it lives and grows. It appeals to him more in the field than it does in the museum.

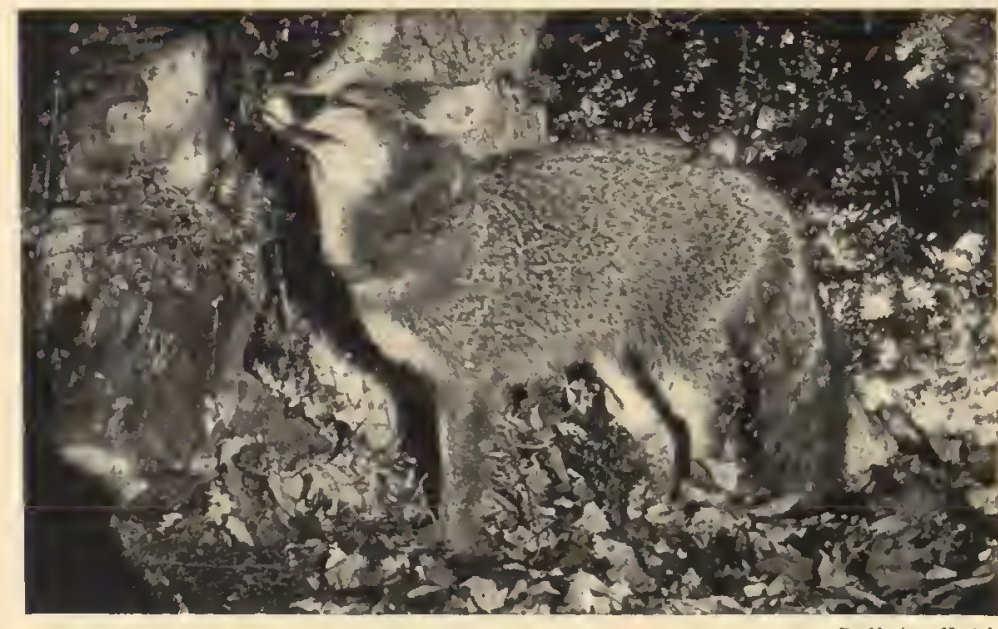

FOX CAUGHT IN A TRAP.

Let him collect for the purpose of understanding a problem. Where does the dandelion grow? What are the plants in yonder bog? How many are the weeds in the orchard? What are the borers in the old $\log$ ? Set the child a field problem and he will collect in spite of himself. Then the collecting has 
teaching power. But to make a collection of one hundred specimens in order to obtain a pass-mark is scarcely worth the effort.

The point I wish to urge is that there is no reason in the nature of things why subjects always should be taught this way or that, so long as they are taught truthfully — and there are many ways of teaching the truth. The way to

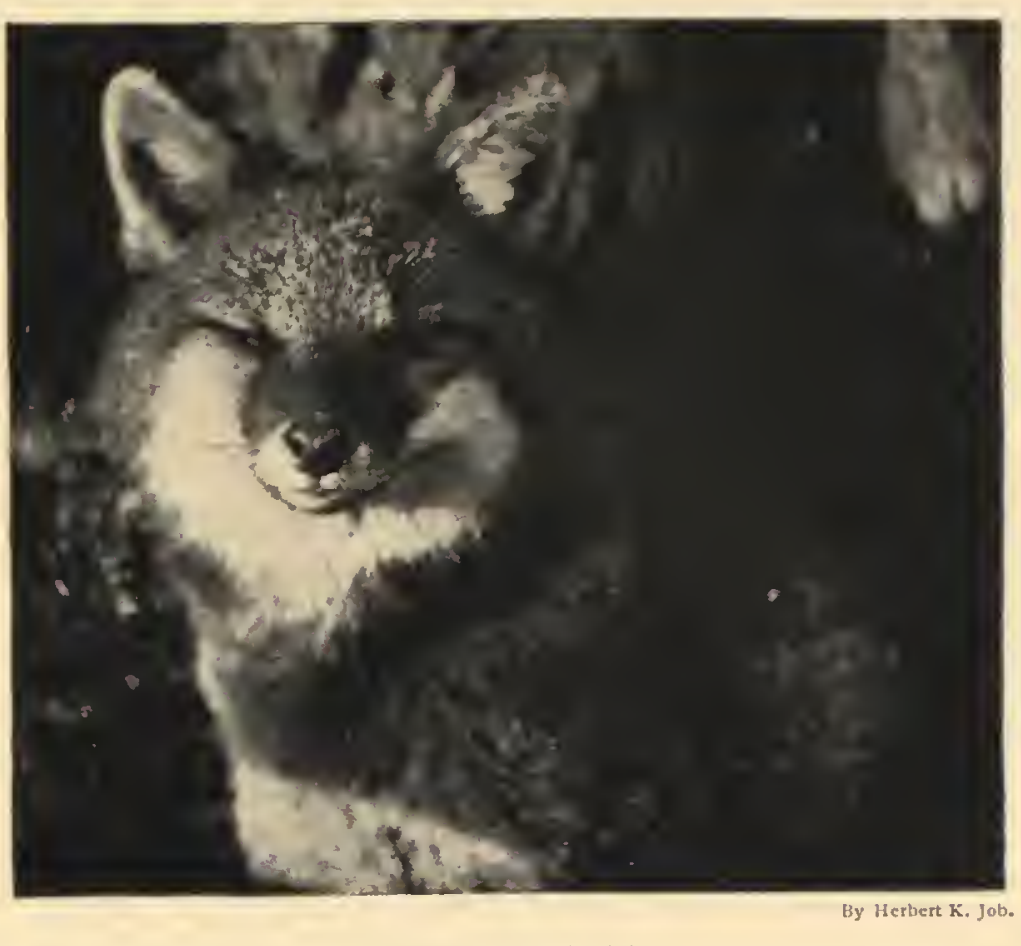

HEAD OF GRAY FOX.

teach is, after all, mostly a matter of experience and expediency. Things were not made either to be analyzed or collected.

All the above remarks are meant to differentiate nature-study from science. Various questions will at once arise in the mind of the teacher.

But do you think that this nature-study will make investigators? That depends on what you mean by an investigator. If you mean an inquirer, then I say that nature-study will develop the trait to perfection. If you mean one who shall discover and record new truth by means of painstaking investigation, then I answer that nature-study will not detract from such attainment. Neither does it lead directly to that end, and this is its merit. To be an investigator is to be a professionalist or specialist; and professionalists should be developed late in the school life from the few who show talent in that direction. Nature-study is for every one, and therefore is fundamental ; scientific investigation is for the few, and therefore is special. If nature-study opens the sympathies natureward, it will also increase the appreciation of science. Too much are our college students taught to make their reputations as investigators. In fact, the student who goes to college or university to study usually thinks only or mostly of investigation - of his science. I wonder whether a science is not worth acquiring as a specialty for the sake of teaching it? May not reputations be made as high-class teachers of ento- 


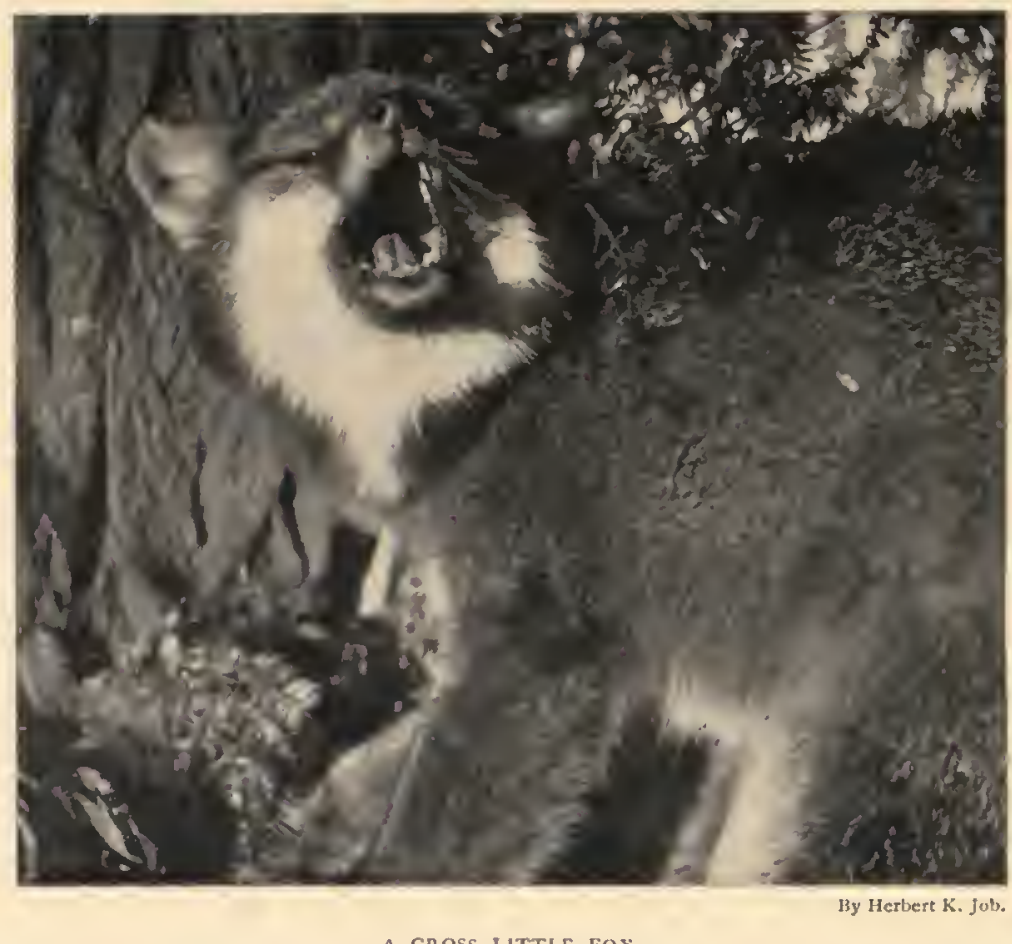

mology or botany, even without ever publishing a bit of technical research? It were better that the teacher be also the investigator, but there are few persons who can make happy union of the two ideals.

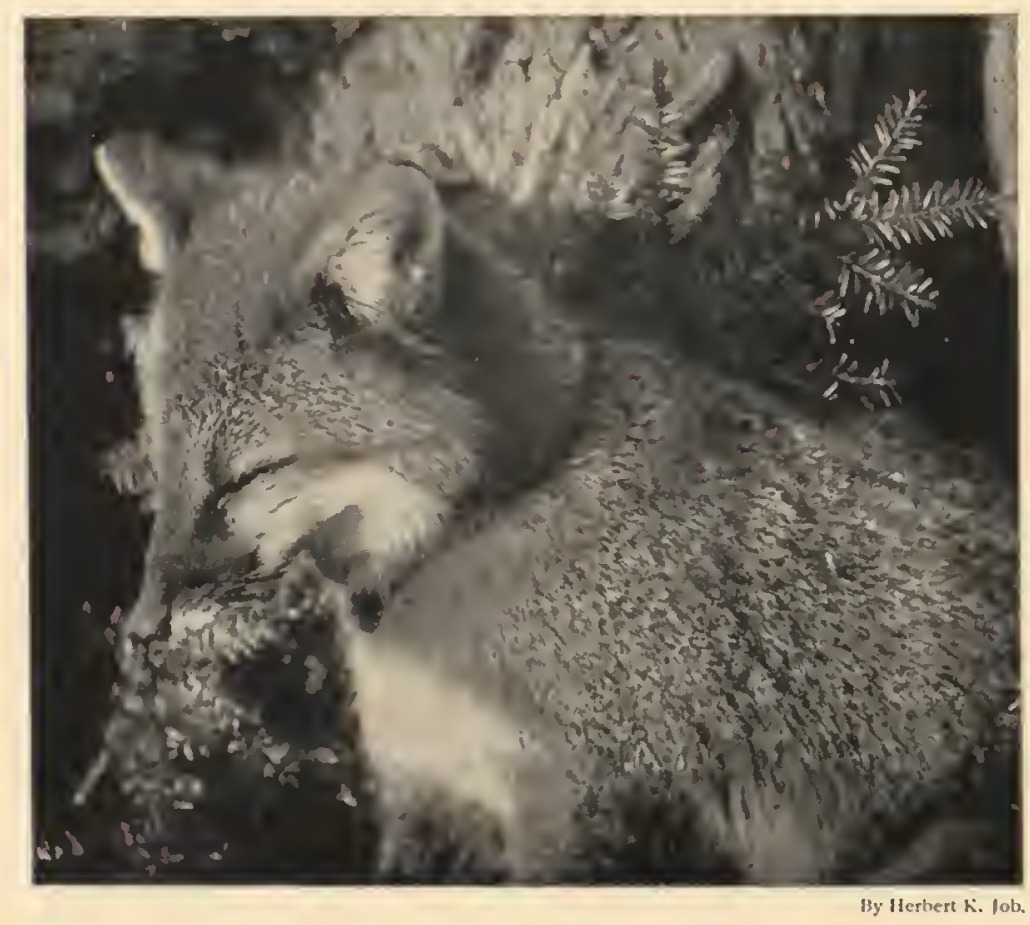

STUDY OF A GRAY FOX. 
DEER IN THE WOODS

A snapshot made at night with a nashlight by W. E. Carlin C.jyright, rnoz, by Doubleday, Fage \& Co. 



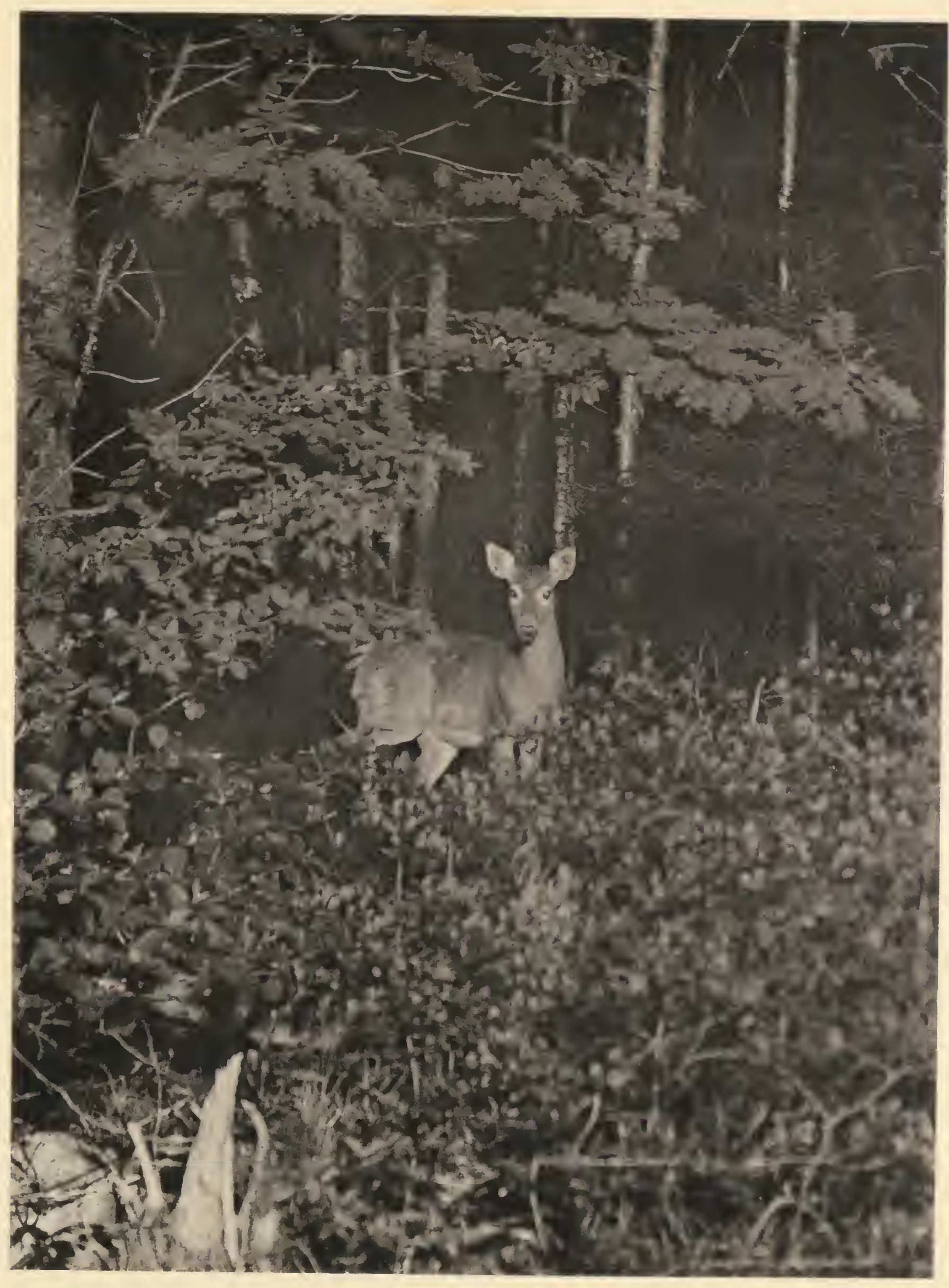


But will not this nature-study be called superficial? No doubt. A botanist told me that I was doing superficial work. Judged from the view-point of science-teaching, he was right; but I was not teaching science. Judged from the view-point of the child, I hope he was wrong. One is not superficial merely because he does not delve deep into subjectmatter. He should be accurate so far as he goes. What is superficiality in the specialist may be commendable thoroughness in the layman. Even the specialist is satisfied with the most superficial knowledge in things outside his specialty. It is notorious that his knowledge of men and of

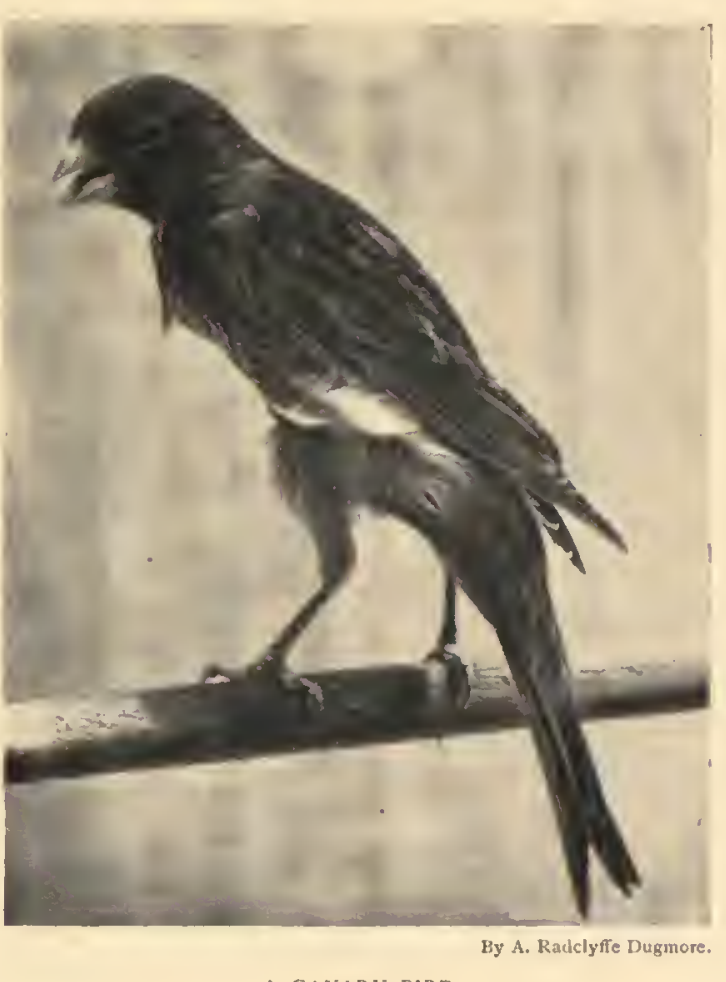

A CANARY-BIRD. business, for example, is superficial.

This charge of superficiality is usually only the opinion of a different point of view. This is well illustrated in the critical reviews of elementary text-

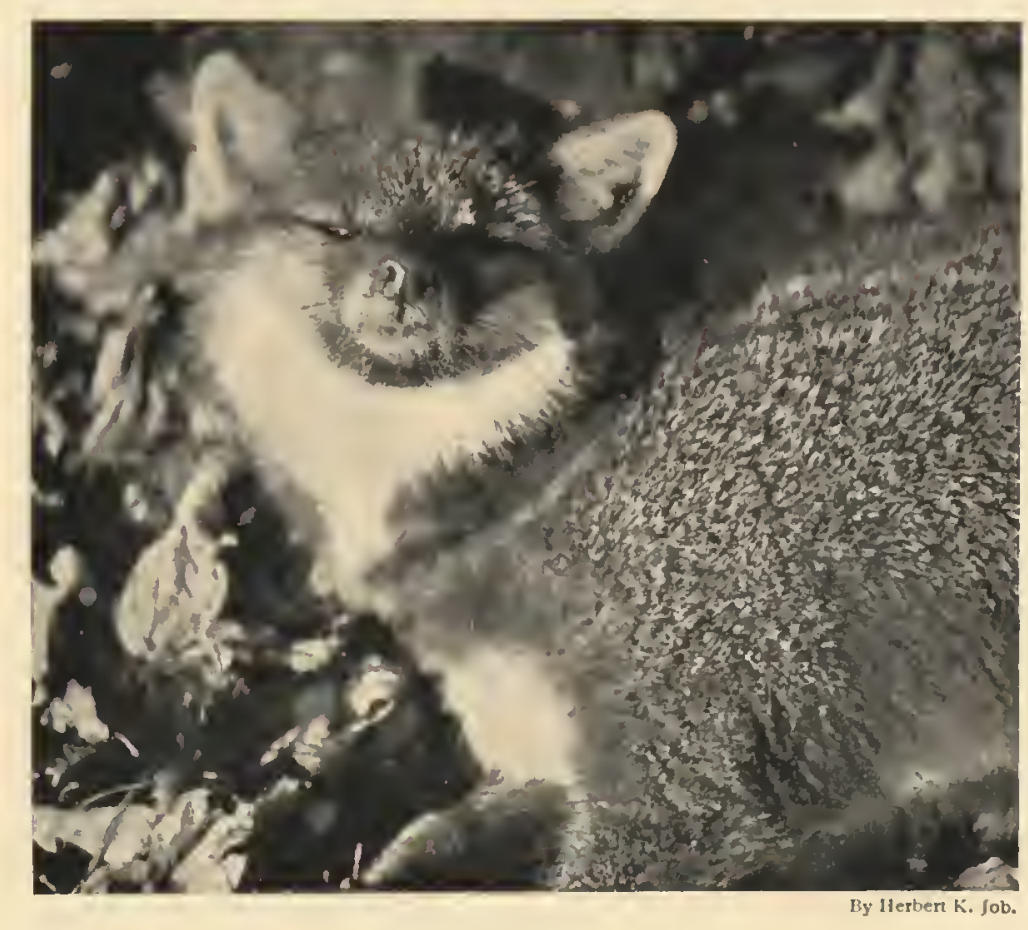

GRAY FOX. 


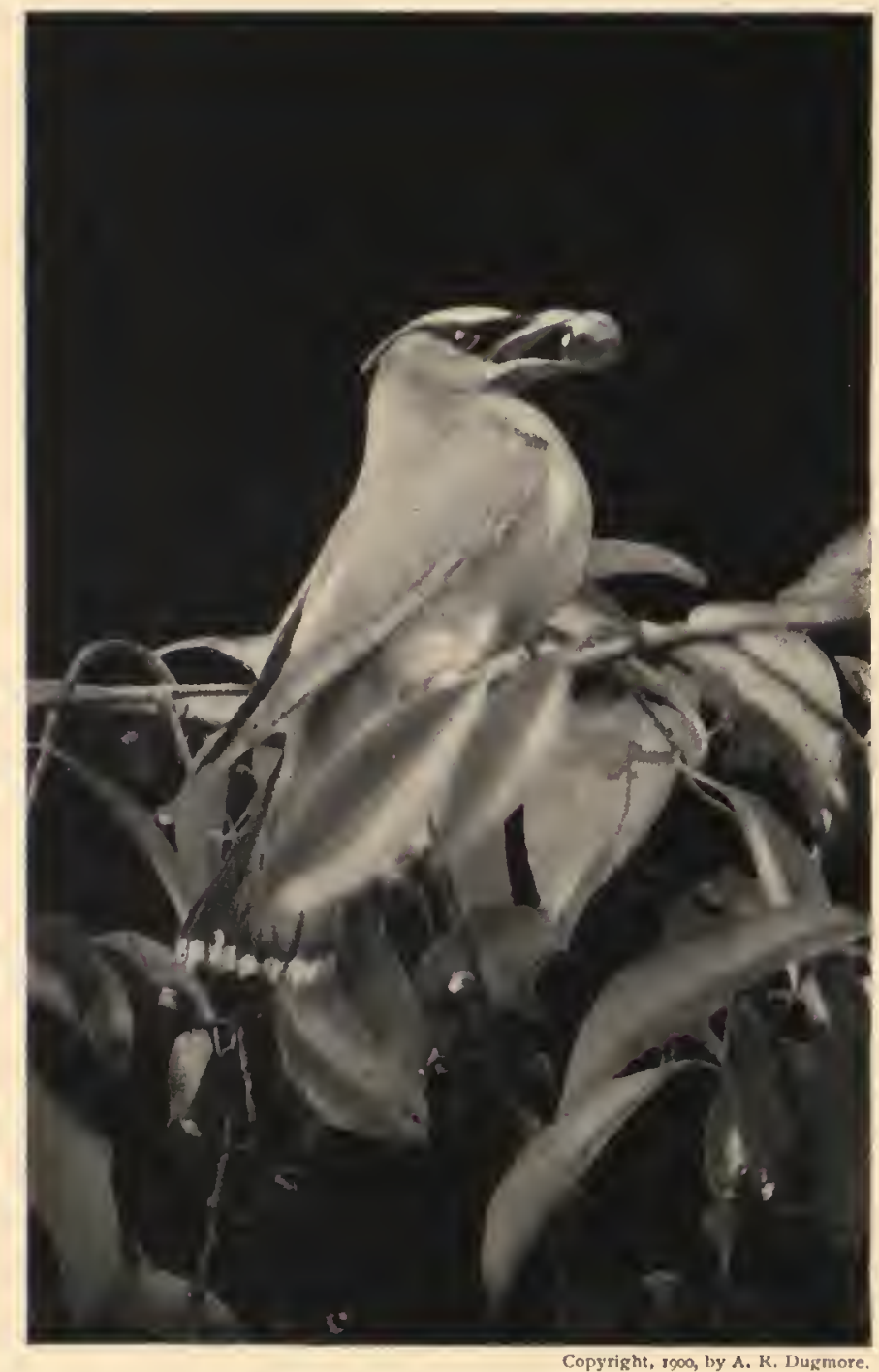

CEDAR-BIRD EATING WILD CHERRIES.

books of science. Books that have been criticized severely by the scientist have been accepted with enthusiasm by the schoolmaster. The primary merit of a school-book lies in its pedagogy rather than in its science. Statements in such books have two values - the teaching value and the science value. Too often the reviewer thinks only of the science value. 


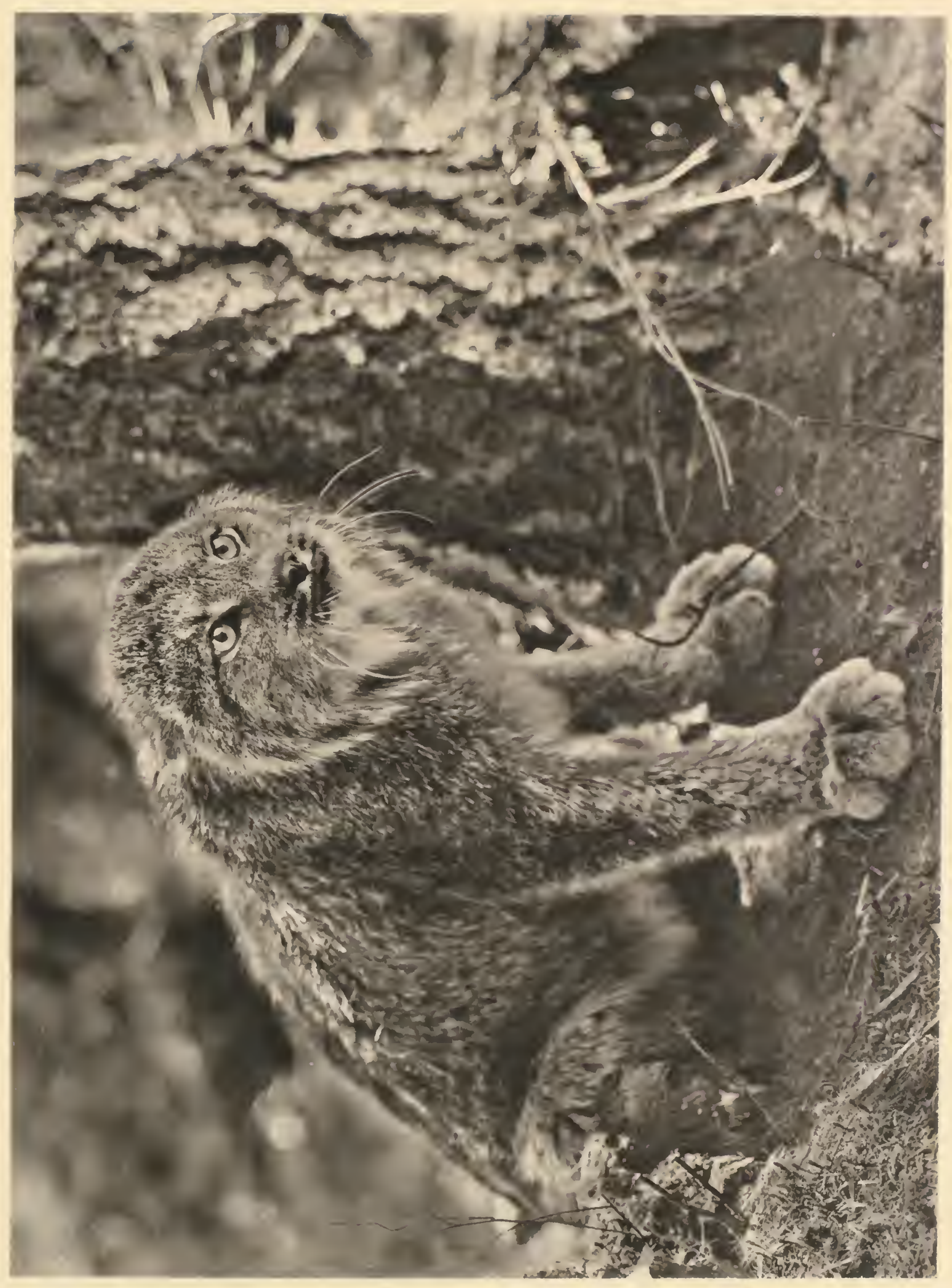




\title{
NATURE PORTRAITS.
}

\author{
$P A R^{\prime} T I V$. \\ THE EX'TRINSIC AND INTRINSIC VIEWS OF NATURE.
}

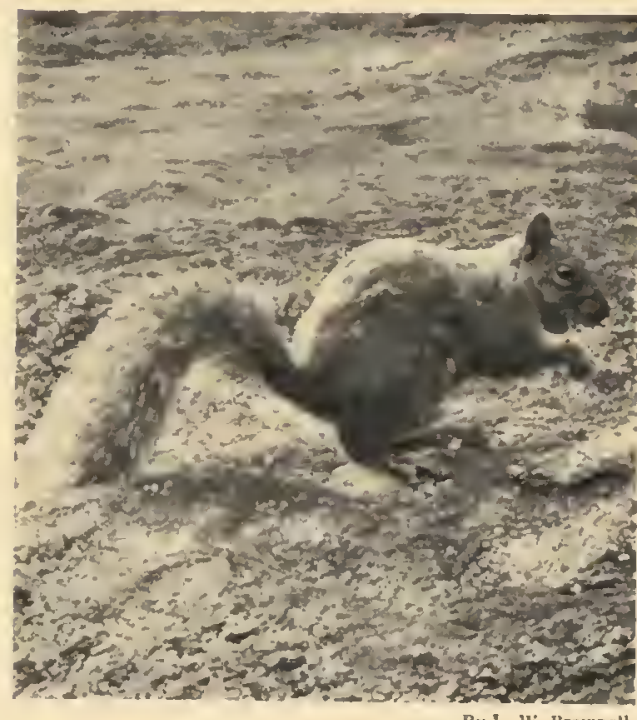

GRAY SQUIRREL.

"The purpose of this exercise is to tell children how to see the hidden beauties of flowers." 'Thus ran the announcement at the opening of the class-room period. Is it worth while to tell them any such thing? Why not teach them to be interested in plants? Why give them a half-truth when they might have the whole truth?

The "beauty" of a flower or a bird is only an incident: the plant or the bird is the important thing to know. Beauty is not an end. The person who starts out to see beauty in plants is often in the condition of mind that the dear old lady was who came into my conservatory and exclaimed, as she saw the geraniums, "Oh, they are as pretty as artificial flowers!"

But these people are not looking for beauty, after all; they look for mere satisfying form or color or oddity. They confound beauty with prettiness or with outward attractiveness. Real beauty is deeper than sensation. It inheres in fitness of means to end as well as in physical attributes. The child should see the thing itself before he sees its parts. Teach first the whole bug, the whole bird, the whole plant. The botanist may well devote his life to a single cell, but the layman wants to know the trees and the woods.

I dislike to hear people say that they love flowers. They should love plants; then they have a deeper hold on things. Intellectual interest should go deeper than mere form or color. Teachers or parents ask the child to see how pretty the object is; but in most cases the child wants to know how it lives and what it does. 

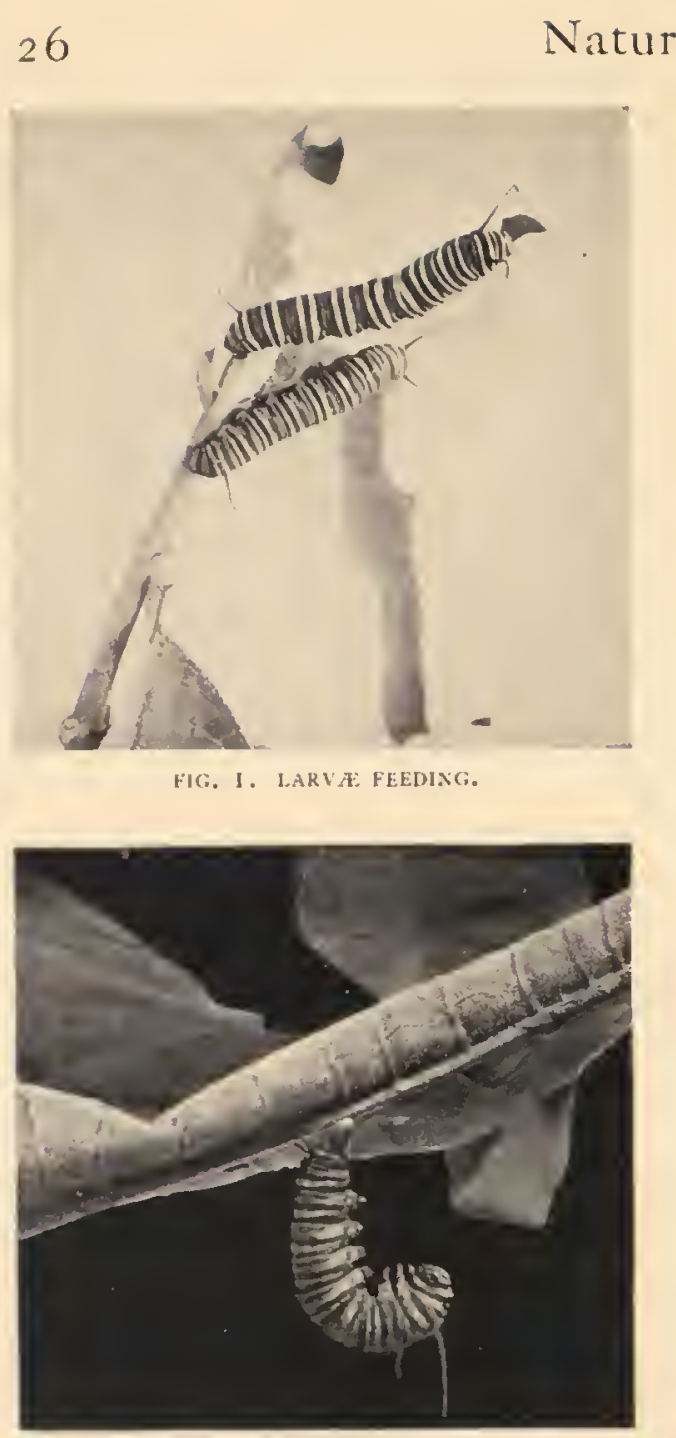

Fig, 2. LARVA HANGING, JUST BFFORE CHaXgiNG TO CHRYSALID.

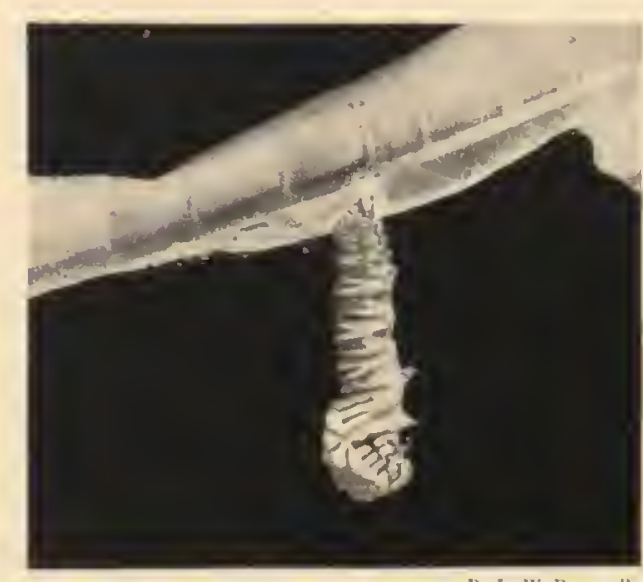

By L. W. Brown
TO EMERGE Fig. 3. Chrysalid BegiNeiNg to EMERGe
FROM SKIN.

It is instructive to note the increasing love for wild animals and plants as a country grows old and mature. This is particularly well illustrated in plants. In pioneer times there are too many plants. The effort is to get rid of them. The forest is razed and the roadsides are cleaned. The pioneer is satisfied with things in the gross. If he plants at all, he usually plants things exotic or strange to the neighborhood. The woman grows a geranium or fuchsia in a tin can, and now and then makes a Hower-bed in the front yard; but the man is likely to think such things beneath him. If a man has flowers at all, he must have something that will fill the eye. Sunflowers are satisfying.

But the second and third generations begin to plant forests and to allow the roadsides to grow wild at intervals. People come to be satisfied with their common surroundings and to derive less pleasure from objects merely because they are unlike their surroundings. Choice plants come in to the yards here and there, and the men of the household begin to care for them. The birds and wild animals are cherished. Love of books increases. All this marks the growth of the intellectual life.

America is a land of cut flowers. Nowhere does the cut-flower trade assume such commanding importance. Churches and homes are decorated with them. One sees the churches of the Old World decorated with plants in pots or tubs. The Englishman or the German loves to 


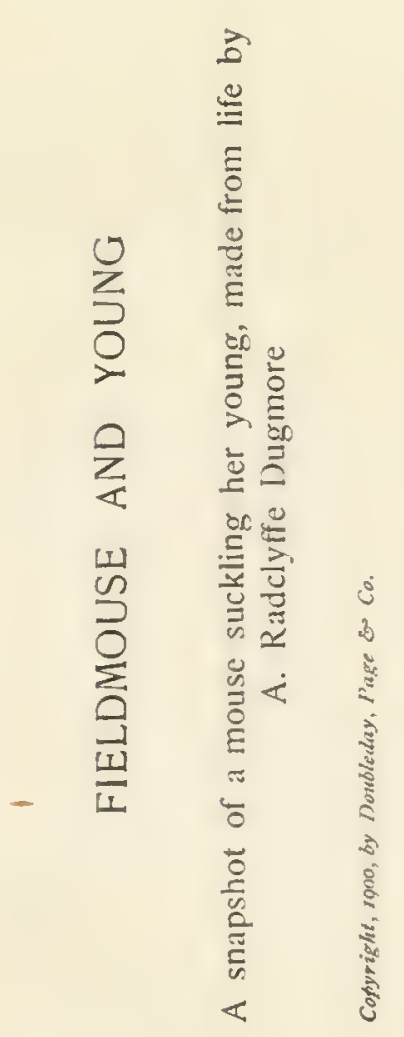





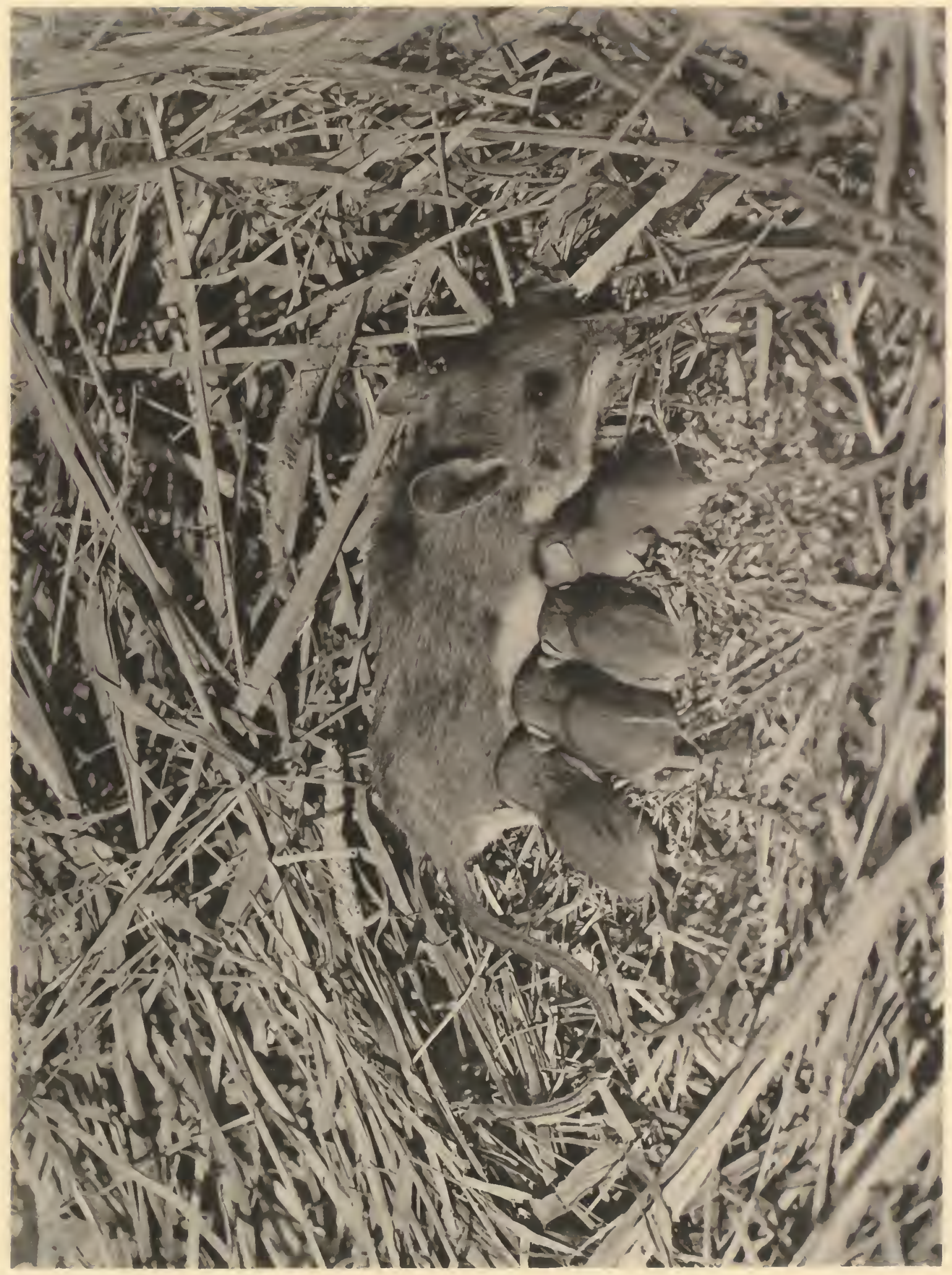


The Extrinsic and Intrinsic Views of Nature 27

care for the plant from the time it sprouts until it dies: it is a companion. The American snips off its head and puts it in his buttonhole: it is an ornament. I have sometimes wondered whether the average flower-buyer knows that flowers grow on plants. Flowers are Heeting.

All of us have known people who derive more satisfaction from a poor plant that never blooms than others do from a bunch of American Beauty roses at five dollars. There is individuality - I had almost said personality - in a growing, living plant, but there is little of it about a detached flower. And it does not matter so much if the plant is poor and weakly and scrawny. Do we not love poor and crippled and crooked people? A plant in the room on wash-day is worth more than a bunch of flowers on Sunday.

But the American taste is rapidly changing. Each year the Horist's trade sees a proportionately greater demand for plants. The same change is seen in the making of parks and home grounds. More and more the gross carpet-beds are relegated to those parts of the grounds which are devoted to curiosities or they are omitted altogether, and in their stead are restful sward and Howing verdure. Flowers are not to be despised, but they are accessories.

This habit of looking first at what we call the beauty of a thing is closely associated with the old conceit that everything is made to please man : man is only demanding his own. It is true that

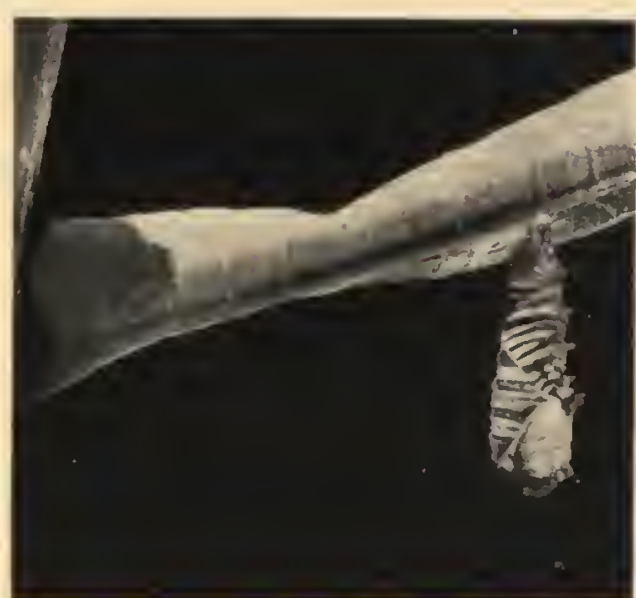

FIG. 4. SKIN HALF-WAY OFF.

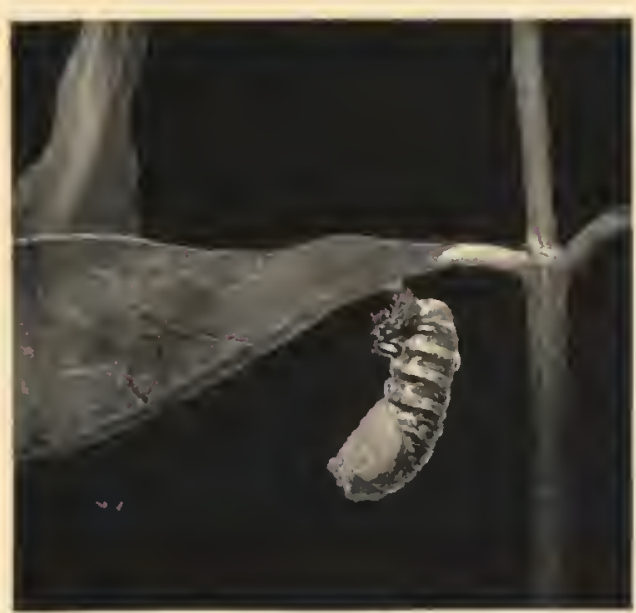

FIG. ¿. CHRYSALID CASTING OFF DISCARDED SKIN.

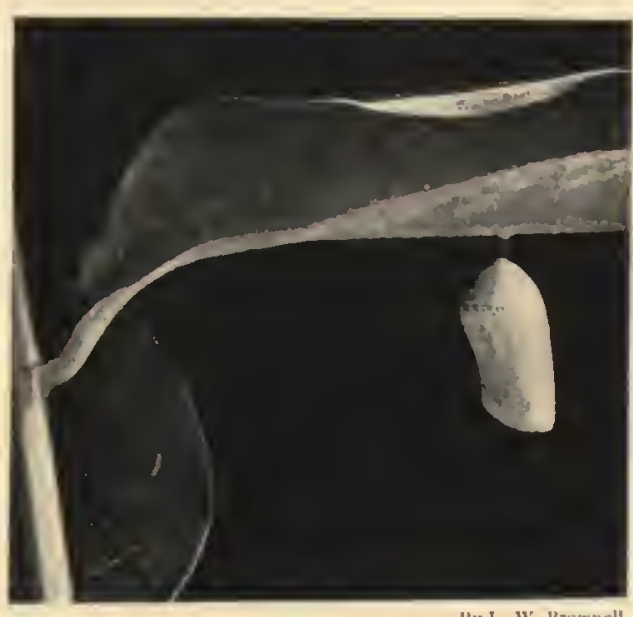

FiG. 6. PEREET CHRYSALID. 


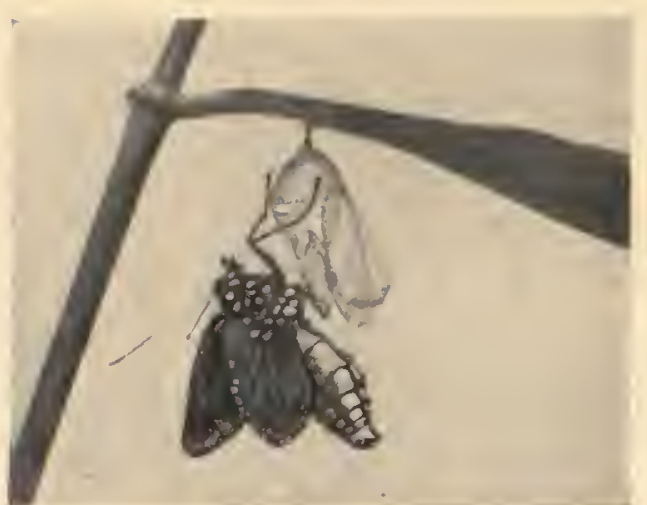

HIC. 7 . BUTTERFLY IMMEDIATELY AFTER FMERGINO FROM CHRYSALID SHELI.

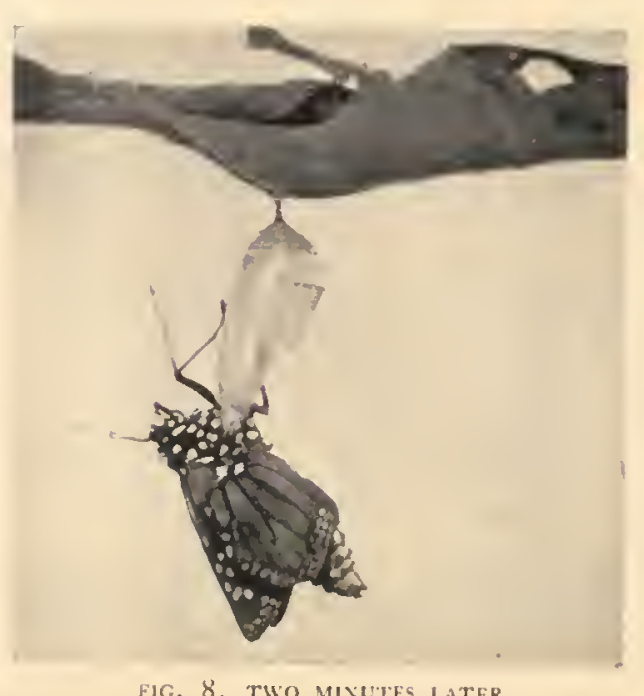

FIG. 8. TWO MINUTES LATER.

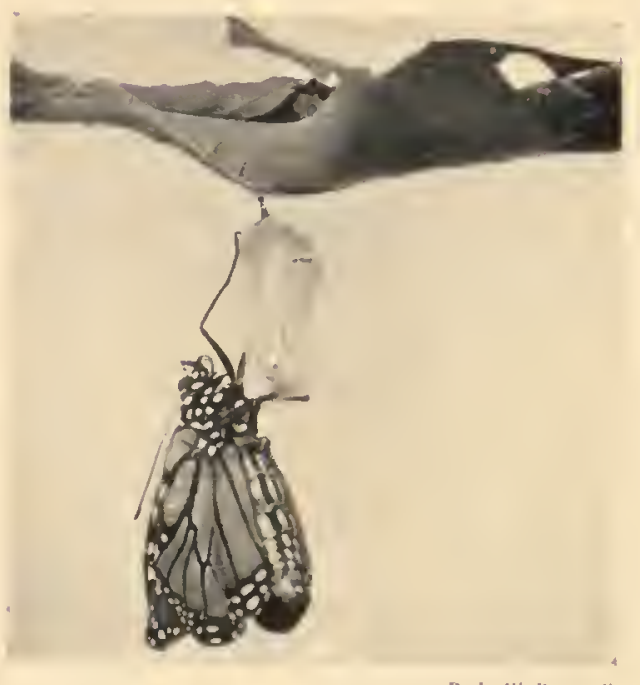

FI6. 9. WRINKLES NEARLY GONE. everything is man's because he may use it or enjoy it, but not because it was designed and made for him in the beginning. This notion that all things were made for man's special pleasure is colossal self-assurance. It has none of the humility of the psalmist, who exclaimed: "What is man, that Thou art mindful of him?"

"What were these things made for, then ?" asked my friend. Just for themselves! Each thing lives for itself and its kind, and to live is worth the effort of living for man or bug. But there are more homely reasons for believing that things were not made for man alone. There was logic in the farmer's retort to the good man who told him that roses were made to make man happy. "No, they wa'n't," said the farmer, "or they would n't 'a' had prickers."

Being human, we interpret nature in human terms. Much of our interpretation of nature is really an interpretation of ourselves. Because a condition or a motive obtains in human affairs, we assume that it obtains everywhere. The only point of view is our own point of view. Of necessity, we assume a starting-point; therefrom we evolve an hypothesis which may be either truth or fallacy. Asa Gray combated Agassiz's hypothesis that species were originally created where we now find them and in approximately the same numbers by invoking Maupertuis's "principle of least action" - "that it is inconsistent with our idea of divine wisdom that the 
The Extrinsic and Intrinsic Vicws of Nature

Creator should use more power than was necessary to accomplish a given end." The result may be secured with a less expenditure of energy than Agassiz's method would entail. But who knows that "our idea of the divine wisdom" is truthful? It is only a human metaphor; but, being human, it is serviceable.

Much of our thinking of nature is but the working out of propositions in logic, and logic is sometimes a substitute for fact. It is impossible to put ourselves in nature's place, - if I may be allowed the personification, - that is, difficult to get the point of view of the thing which we are studying. If it were possible to get that point of view, it would be an end to much of our speculation: we should deal with fact.

We hope that we are coming nearer to an intrinsic view of animals and plants; yet we are so intent on discovering what ought to be that we forget to accept what is.

Would you begin by first reading to the child about nature? No. The reading should come after, not before. Order will gradually come out of experience. The child should first come in contact with things rather than with ideas about things. 'This is the natural order. Animals come before zoölogy, plants before botany, fields and rocks before geology, words before language, religion before theology. Experience comes before theory.

Shall we teach the child to collect, and thereby to kill? How much or how little the collecting habit shall be en-

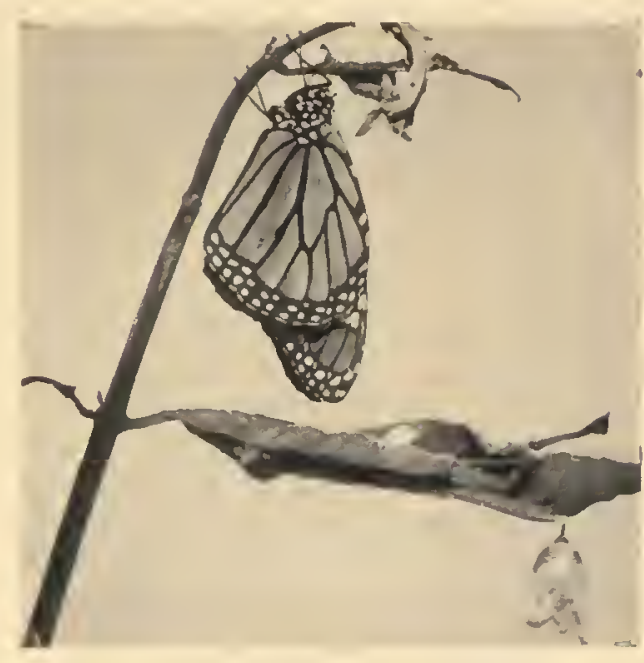

FIG. 10 . WINGS FULLY EXPANDED.

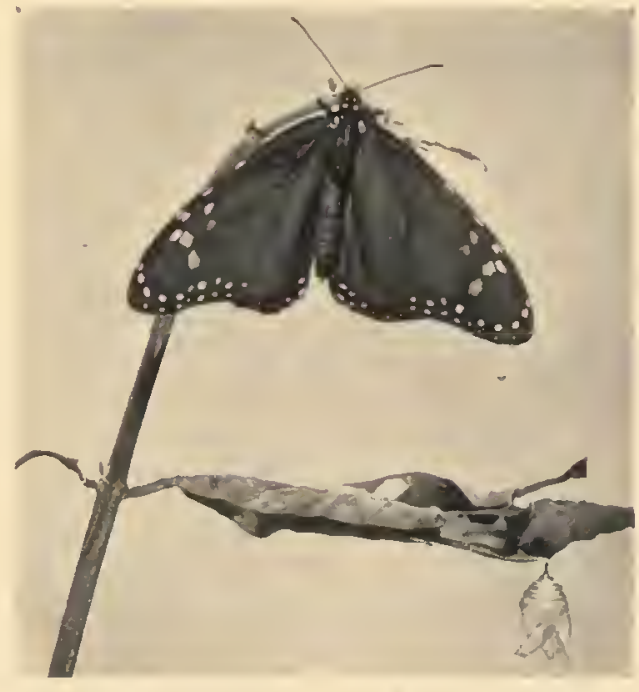

FIG. 11. TESTING AND DRYING THE WINGS.

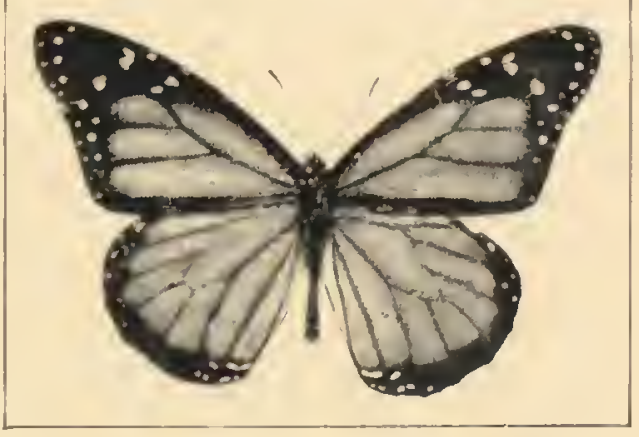

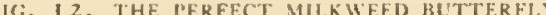




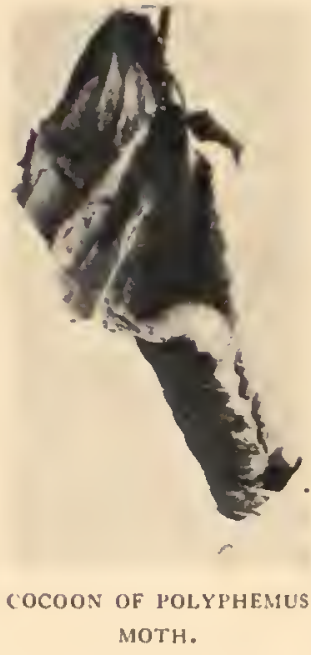

MOTH.

couraged must be determined for each case by itself; but, in general, the child should be taught to respect the life of every creature. Collecting should be a mere incident, particularly with very young children, and it should be encouraged only when it has some definite purpose. The wanton spirit always must be suppressed. I do not like to encourage young children to "catch things" for the mere excitement of catching them. Study the habits of things as they are. I have little sympathy with the development of mere sentimentalism regarding the life of animals and plants; but it is a safe principle, with children, to let everything live its own life. Discourage the spirit of the hunter.

Now that there are so many nature-books, how shall I choose the most useful one? Only by finding out what you want. The multitude of books may be confusing, but the greater the number the greater is the chance that you will find one to your liking. Some people deplore the making of many books, because they then have more difficulty in choosing;

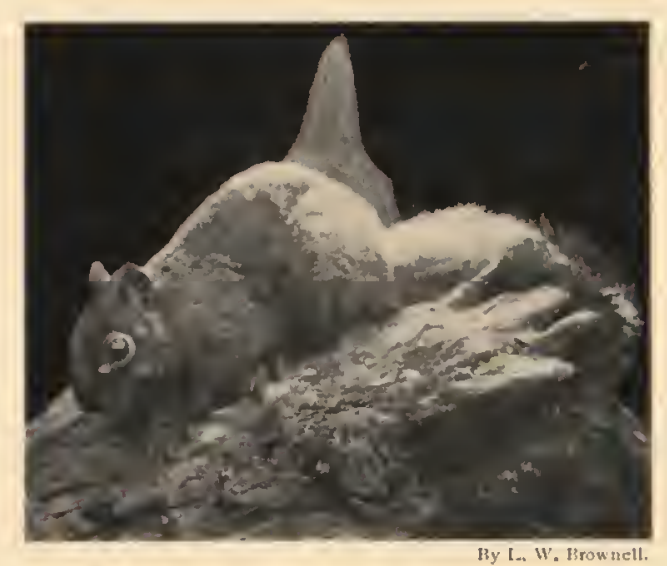

FOX SQUIRRFI.

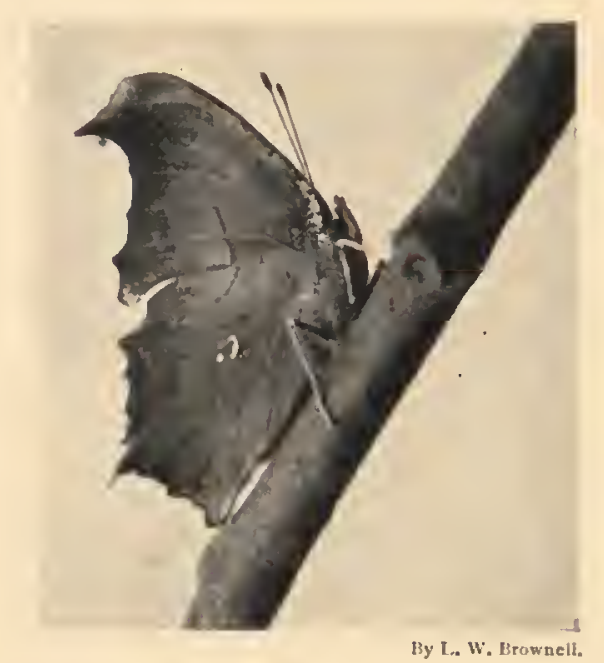

ANGLL-WING BUTTERFLY-ONE OF THE EARIY SPRING VISITORS.

but the time has already passed when one book, or even two, can satisfy a good teacher. The teacher may not be able to purchase several books, but the school should supply a reasonable number. In these days the library is part of the equipment of the school. There is a general feeling that a new book-particularly a new schoolbook - is made for the purpose of displacing some other book. I once wrote a book. It seemed to occupy a field for which one of my best friends also had written. This friend wrote that perhaps I was right and he was wrong. I replied 
A DISREPUTABLE PAIR

Two owls photographed by A. Radclyffe Dugmore 


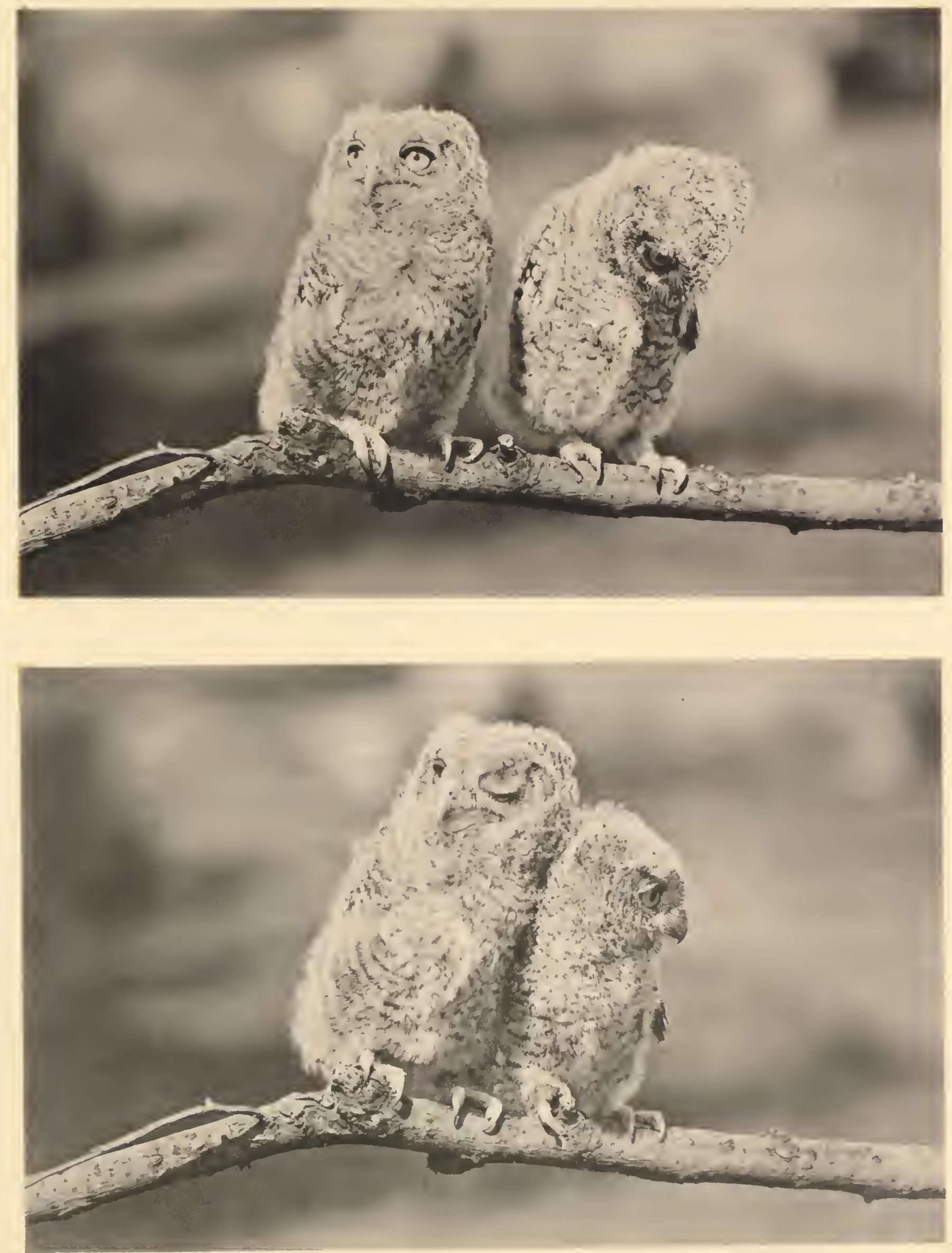

The Extrinsic and Intrinsic Views of Nature 31

that I hoped I was right, but that this did not imply that he was wrong. I hope that we are both right. There is more than one point of view. Botanists sometimes deplore the number of text-books. As a matter of fact, we need more rather than fewer; thereby is there greater likelihood that every teacher can find a book to his liking. I do not believe that we should have uniform methods of teaching any subject in all parts of the country. When one text-book satisfies everybody, it is because nearly everybody is uncritical and unpersonal.

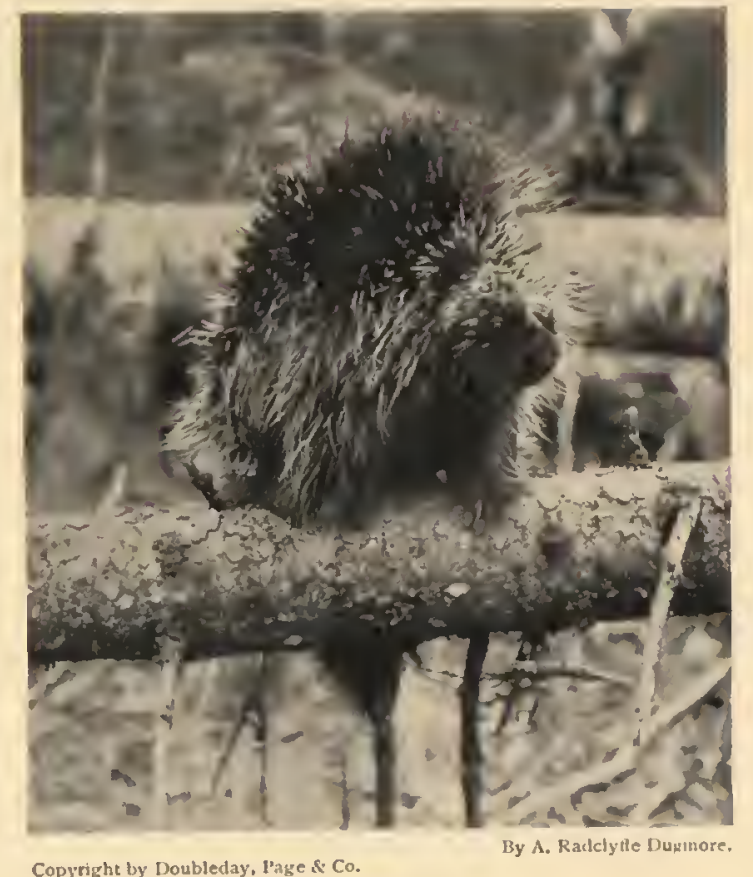

Copyright by Doubleday, lage is Co.

PORCUDiNe.
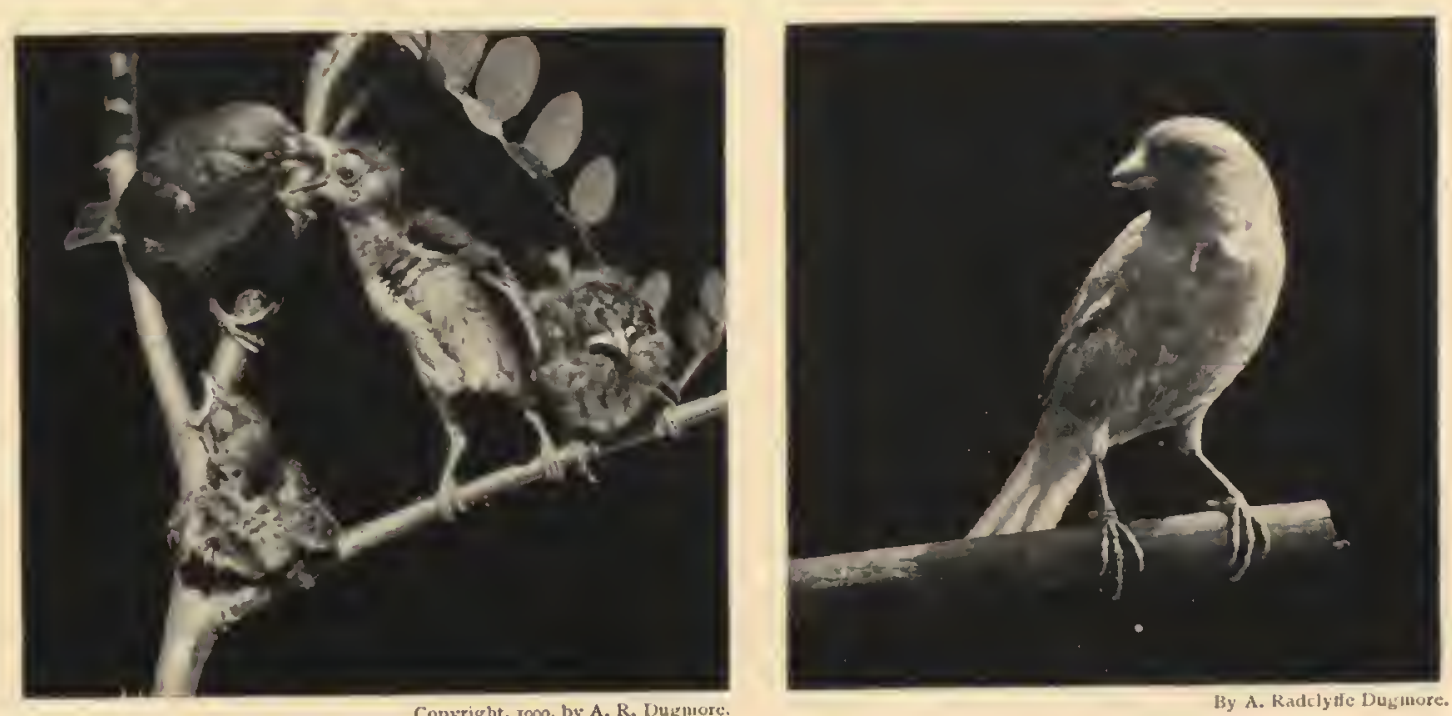

Copyright, s9oo, by A. R. IJugmor

SPARROW FEFDING HER YOUNG,

a PET CANARY. 


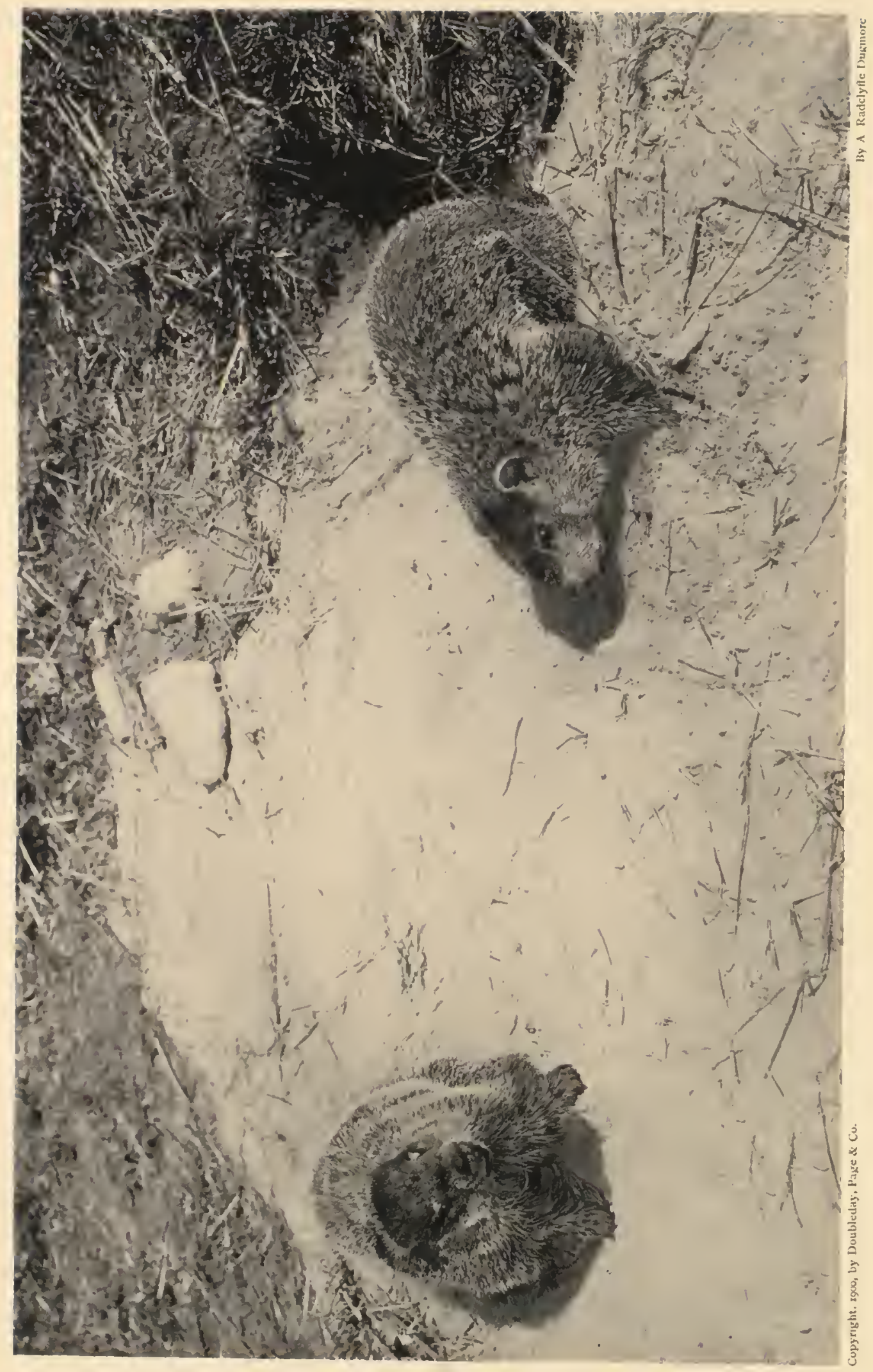




\title{
NATURE PORTRAITS.
}

\author{
PAR'T $V$.
}

THE POETIC INTERPRETATION OF NATURE.

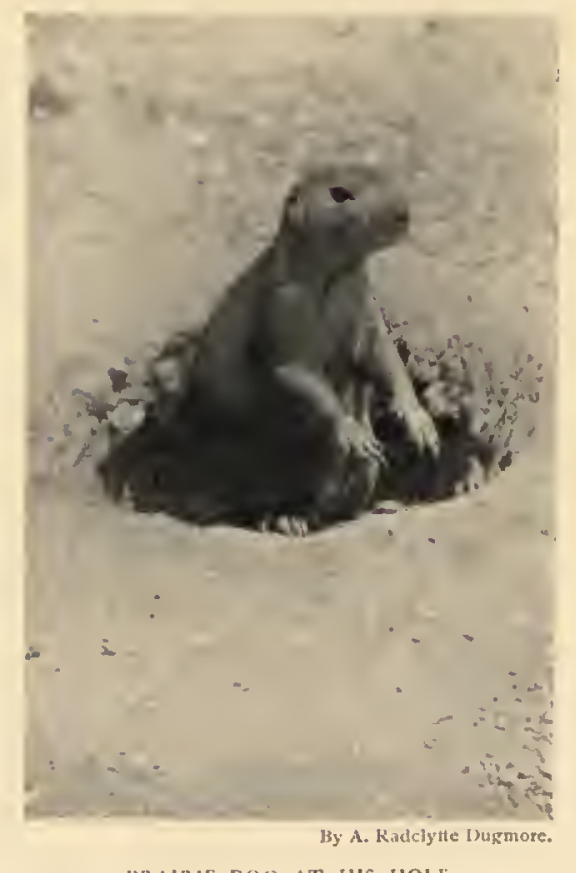

PRAIRIE-DOG AT HIS HOLE.

MERRILY swinging on brier and weed, Near to the nest of his little dame,

Over the mountain-side or mead, Robert of Lincoln is telling his name:

Bob-o'-link, bob-o'-link, Spink, spank, spink ;

Snug and safe is that nest of ours,

Hidden among the summer flowers.

Chee, chee, chee.

Robert of Lincoln is gaily drest,

Wearing a bright black wedding-coat;

White are his shoulders and white his crest.

Hear him call in his merry note:

Bob-o'-link, bob-o'-link,

Spink, spank, spink;

Look what a nice new coat is mine,

Sure there was never a bird so fine.

Chee, chee, chee.

Robert of Lincoln's Quaker wife,

Pretty and quiet, with plain brown wings,

Passing at home a patient life,

Broods in the grass while her husband sings:

Bob-o'-link, bob-o'-link,

Spink, spank, spink ;

Brood, kind creature; you need not fear

Thieves and robbers while I am here.

Chee, chee, chee. 
Modest and shy as a nun is she;

One weak chirp is her only note.

Braggart and prince of braggarts is he,

Pouring boasts from his little throat:

Bob-o'-link, bob-o'-link,

Spink, spank, spink;

Never was I afraid of man;

Catch me, cowardly knaves, if you can! Chee, chee, chee.

Six white eggs on a bed of hay,

Flecked with purple, a pretty sight!

There as the mother sits all day,

Robert is singing with all his might:

Bob-o'-link, bob-o'-link,

Spink, spank, spink;

Nice good wife, that never goes out,

Keeping house while I frolic about.

Chee, chee, chee.

Soon as the little ones chip the shell,

Six wide mouths are open for food;

Robert of Lincoln bestirs him well,

Gathering seeds for the hungry brood.

Bob-o'-link, boh-o'-link,

Spink, spank, spink;

This new life is likely to be

Hard for a gay young fellow like me.

Chee, chee, chee.

Robert of Lincoln at length is made

Sober with work, and silent with care;

Off is his holiday garment laid,

Half forgotten that merry air :

Bob-o'-link, bob-o'-link,

Spink, spank, spink;

Nobody knows but my mate and I

Where our nest and our nestlings lie.

Chee, chee, chee. 
1 



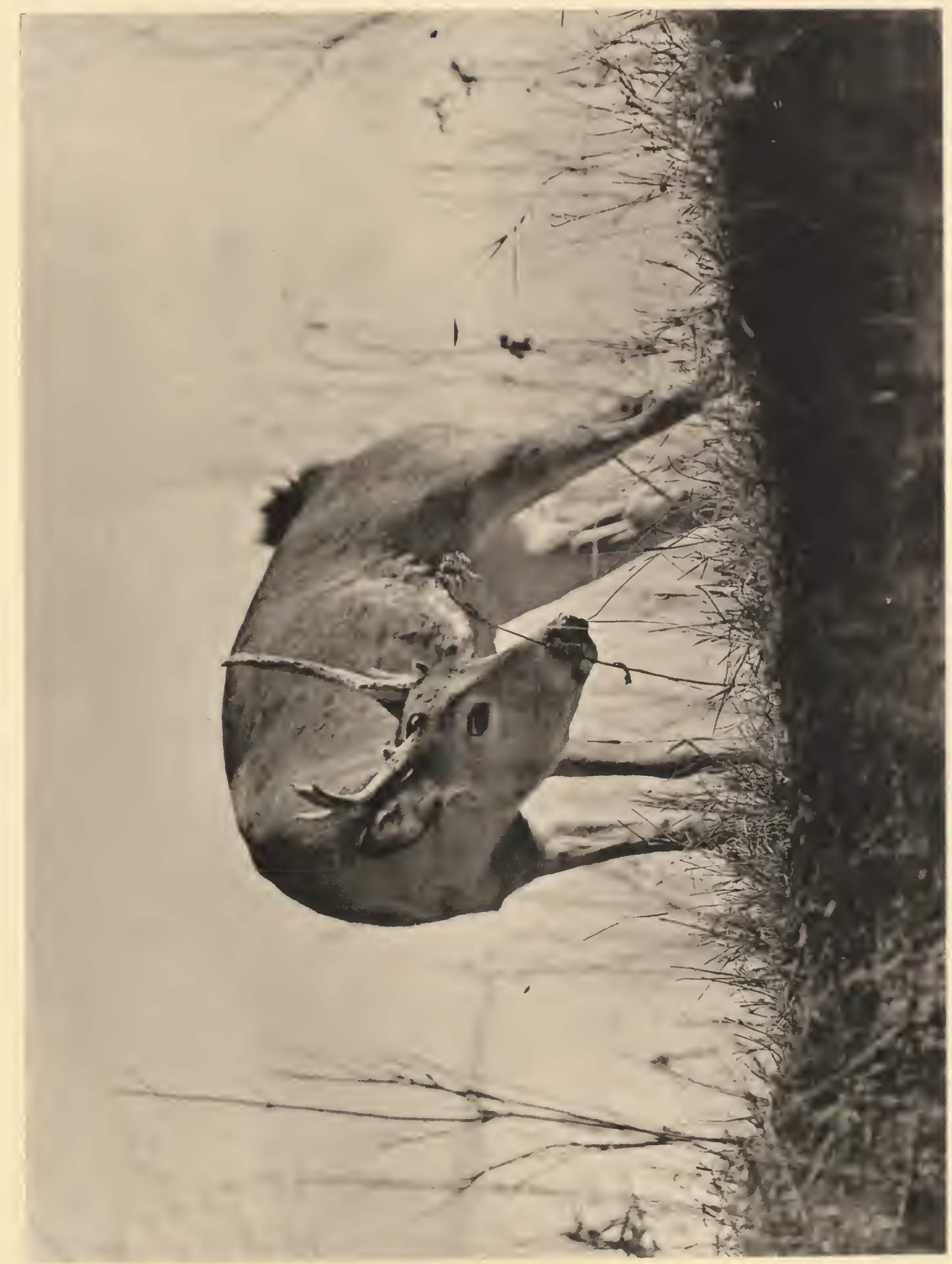





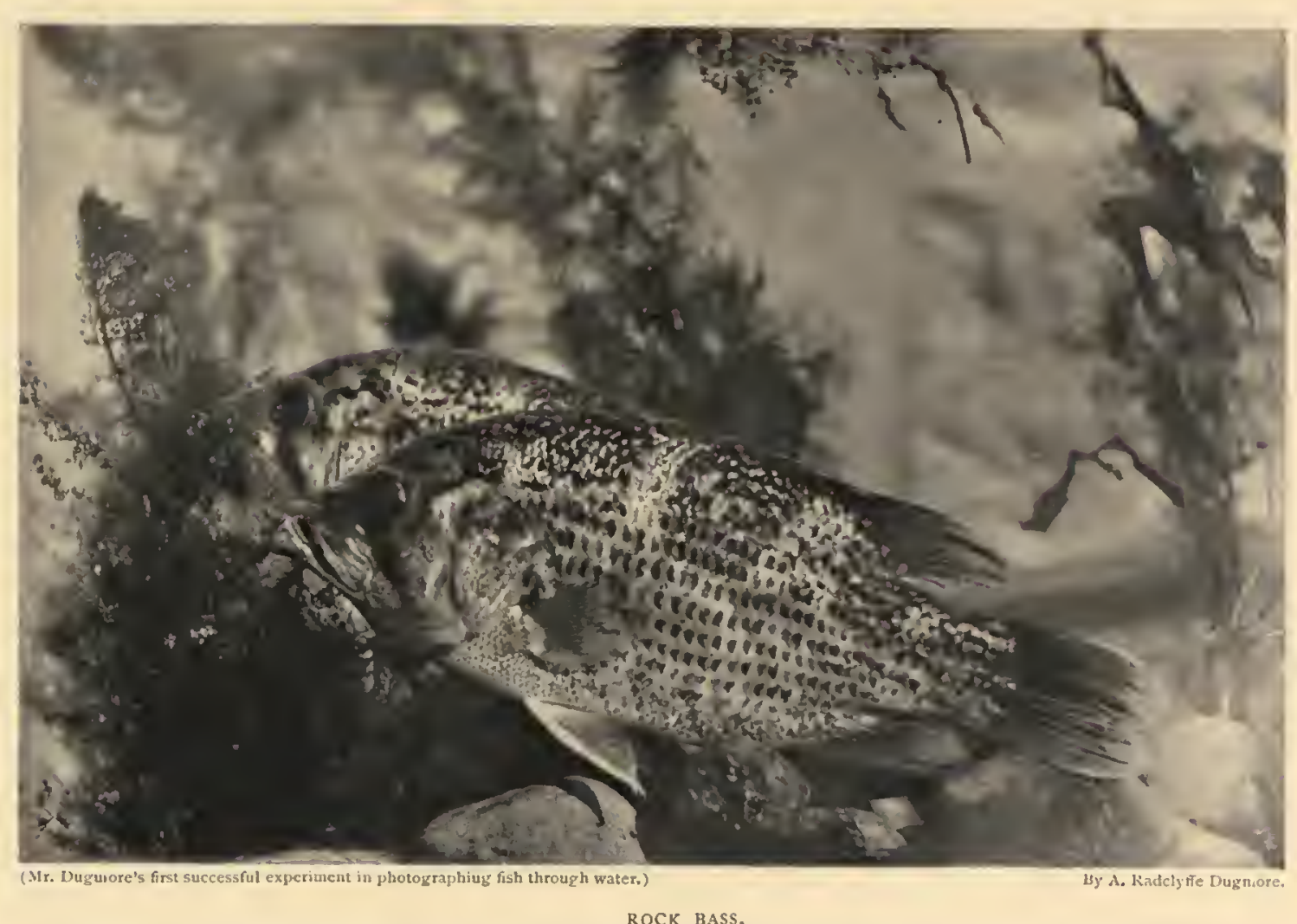

ROCK BASS.

Summer wanes; the children are grown;

Fun and frolic no more he knows;

Robert of Lincoln's a humdrum crone;

Off he flies, and we sing as he goes:

Bob-o'-link, bob-o'-link,

Spink, spank, soink;

When you can pipe that merry old strain, Robert of Lincoln, come back again.

Chee, chee, chee.

This was the lesson which the children were having as I visited the school on a June morning. It was the new old song by which Bryant is re-

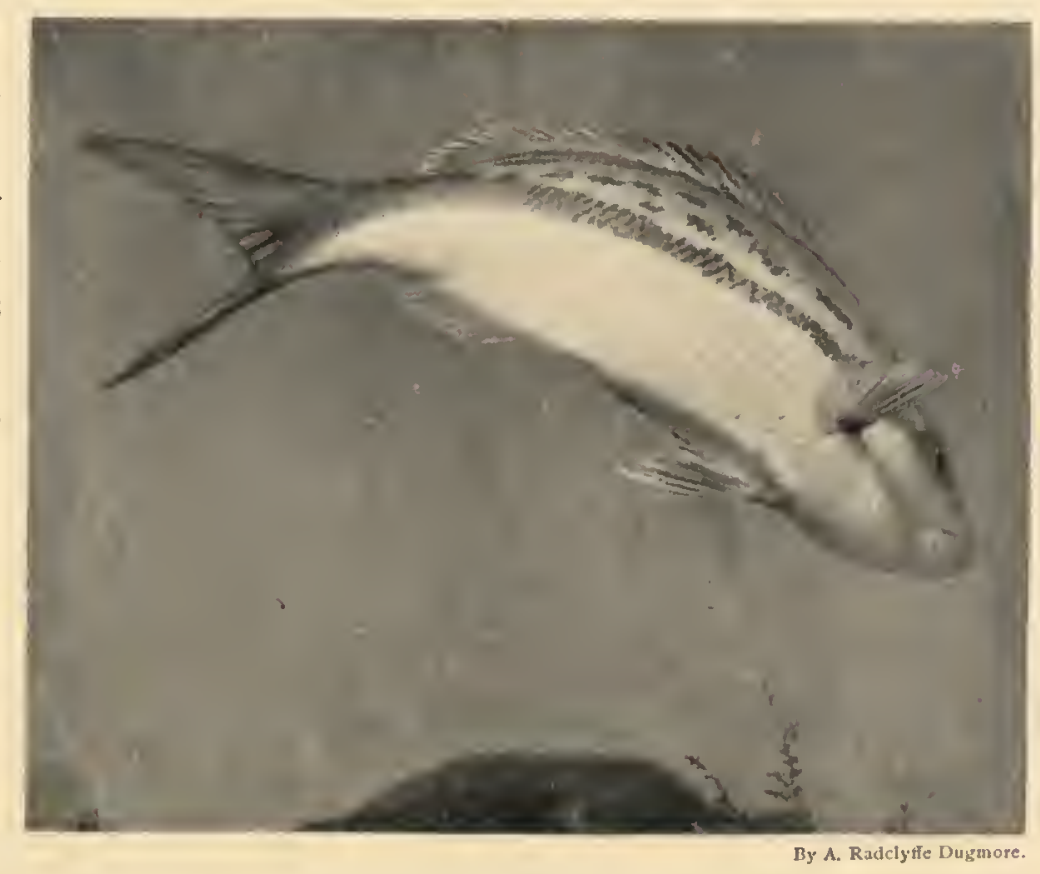

YELLOWTAL. 


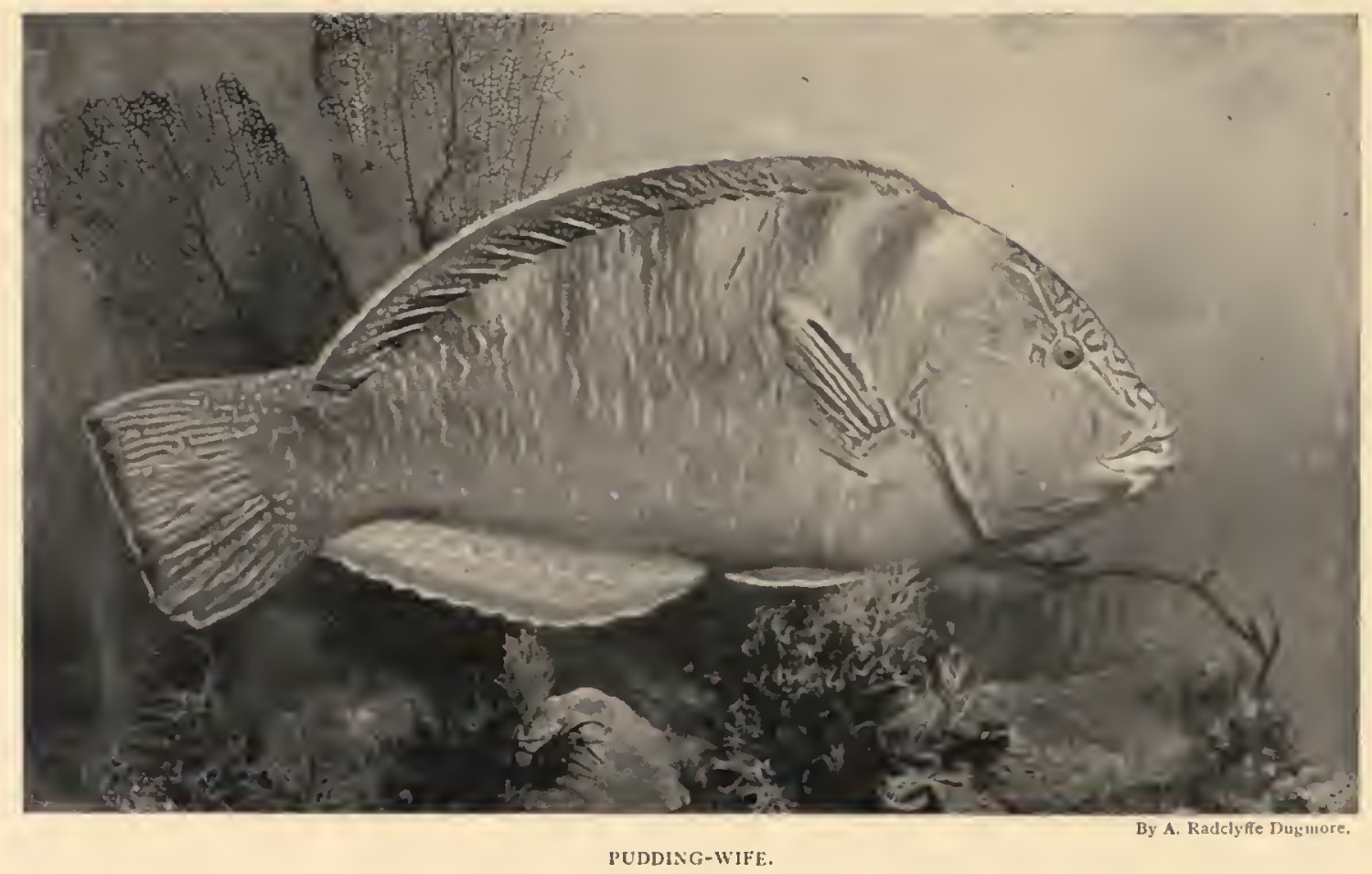

membered of the country boy and girl. The children had seen the bobolink. They had heard the liquid rattle of his song. They had seen the nest in the grass. They had watched for the Quaker wife. They had seen the purple-flecked eggs. They knew that Robert of Lincoln would soon leave them. The poem touched their hearts, and they knew the bobolink better.

With enthusiasm I related the experience to my friend, the teacher of natural history in the college. He checked my ardor. He saw only

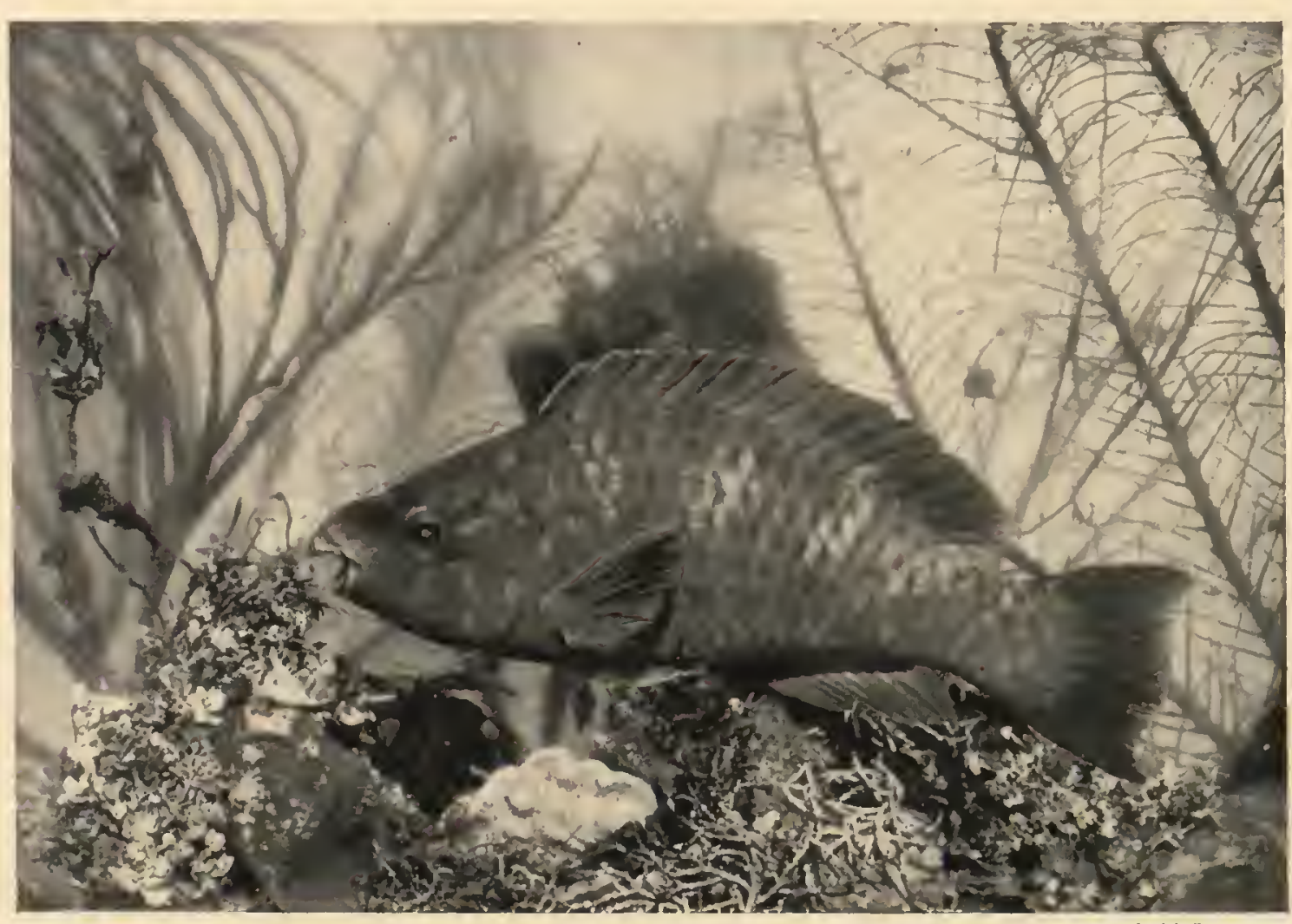

I'ARROT-FISH.

By A. Radclyffe Duymore 
danger in such teaching. It tends to looseness of ideas. It makes the mind discursive. It does not fix and fasten the attention to the subject-matter. It is unscientific. The child could learn poetry by the yard, he said, and yer not know how many toes the bobolink has, nor the shape and size of its wings. The pupil gains no comparative knowledge of bird with bird. The poem is untrue. The bobolink is not "drest": he has no clothes. He has no wife: he is mated, not wed.

I could only reply that the bobolink's toes have little relation to men's lives, however much they may have to bobolinks' lives; but the bobolink may mean niuch to men's lives. To a man pursuing science for science's sake - and I wish there were more - the toes are important; but these men are desirous of information, whereas I am seeking a fresh and firmer hold on life. To be sure, I should study the bobolink before I studied the poem, if possible; but I should want a real bobolink, not a stuffed specimen. If I were obliged to choose between lessons on stuffed bobolinks and the poem, I should take the poem : there is more bobolink in it.

The other day a young man wanted me to recommend him as a teacher of one of the sciences in a public school. He explained that he had had a complete course in this and in that; he could teach the whole subject as laid down in the books; he knew the methods. It was evident that he was well drilled. He had acquired a fund of well-digested but unrelated facts. These facts were carefully assorted and ticketed, and tucked away in his mental cupboard, as embroidered napkins are laid away in a drawer. Poor fellow! Mere details have little educative value.

I like the man who has had an incomplete course. A partial view, if . truthful, is worth more than a complete course, if lifeless. If the man has acquired a power for work, a capability for initiative and investigation, an enthusiasm for the daily life, his incompleteness is his strength. How much there is before him! How eager his eye! How enthusiastic his temper! He is a man with a point of view, not a man with mere facts. This man will see first the big and significant things; he will grasp relationships; he will correlate; later he will consider the details. He will study the plant before he studies the leaf or germination or the cell. He will discover the bobolink before he looks for its toes. He will care little for mere "methods."

This is the age of fact, and this is well. But it may be also the age of the imagination. Fact is not to be worshiped. The life which is devoid of imagination is dead; it is tied to the earth. There need be no divorce of fact and fancy; they are only the poles of experience. What is called the

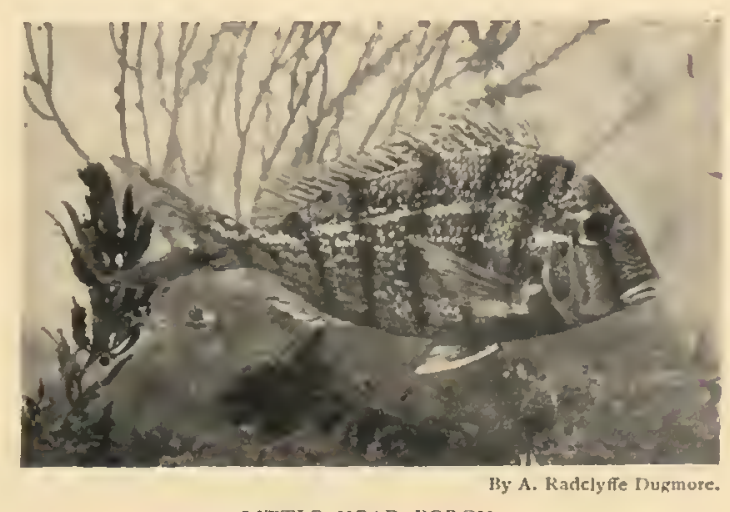

LITTLE-HEAD PORGY. 


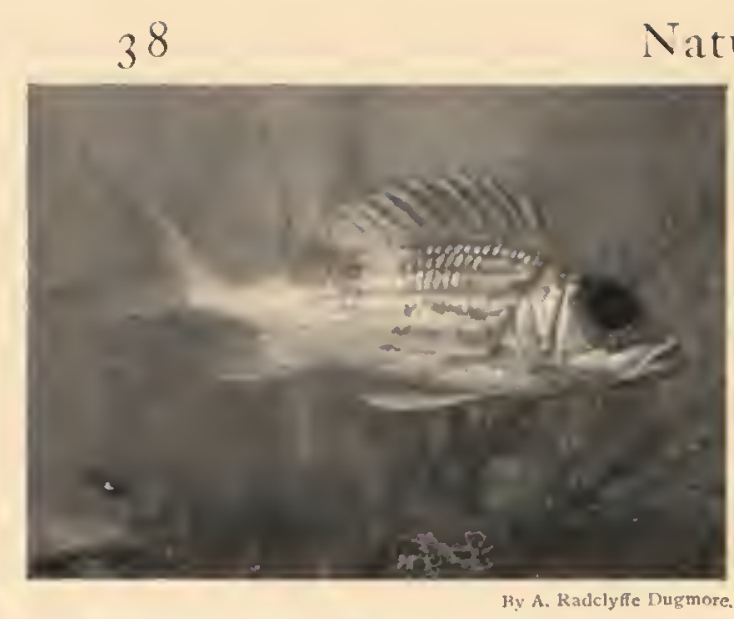

SQLIRREL-FISH,

Nature Portraits

scientific method is only imagination trained and set within bounds. Compared with the whole mass of scientific attainment, mere fact is but a minor part, after all. Facts are bridged by imagination. They are tied together by the thread of speculation. The very essence of science is to reason from the known to the unknown.

We have a right to the poetic interpretation of nature. It is essential only that the observation is correct and the inference reasonable. In teaching science we may confine ourselves to scientific formulas, but in teaching nature we may admit the spirit as well as the letter. If I were making a curriculum for the study of nature, I should include a course in English poetry.

In our day of science, people seem to be afraid of sentiment. The scientist forbids us to personify; and this is well. But this spirit may be carried so far as to forbid figures of speech and to condemn parables. Speech cannot be literally accurate. Even astronomers say that the sun sets, but we know that it does not. The trouble with much of the

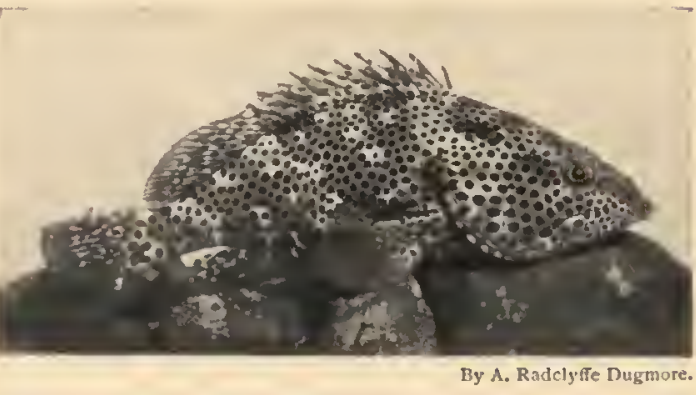

ROCK-HIND. sentiment is that it gives us a wrong point of view. To say that a potatoplant works all the season in order to provide for its offspring the next year is said to give a wrong conception of the plant because it implies motive. But does this picture mislead any one? Everybody knows that a potatoplant has no brains. Everybody knows that the statement conveys a truth. Under certain conditions I believe that it is perfectly justifiable. If it is not,

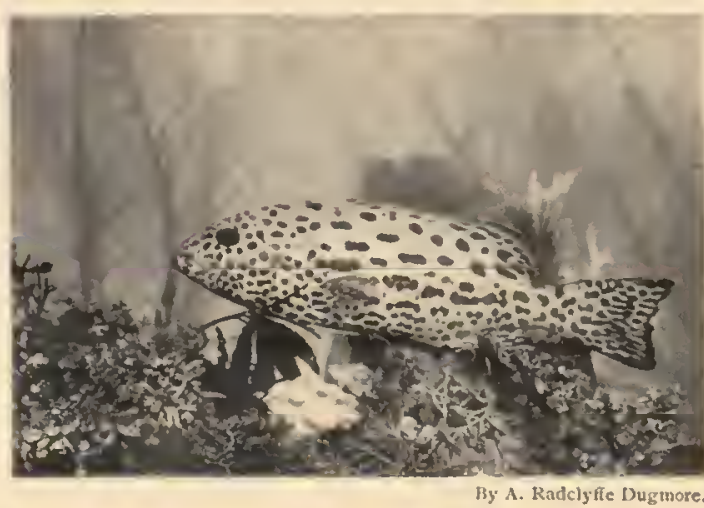

YELLOW-FIN GROUPER. then I may not say that a potato has eyes. Much of the objection to statements of this kind is mere quibbling. But, on the other hand, all such allegories must be true in spirit and in their teaching. Much of the current writing of plants and animals, by which human motives are implied, is productive of harm. It is 


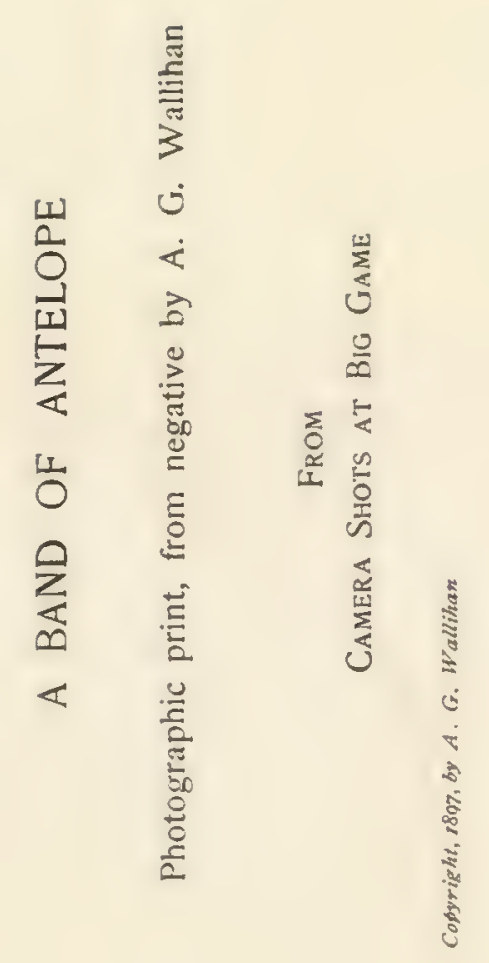





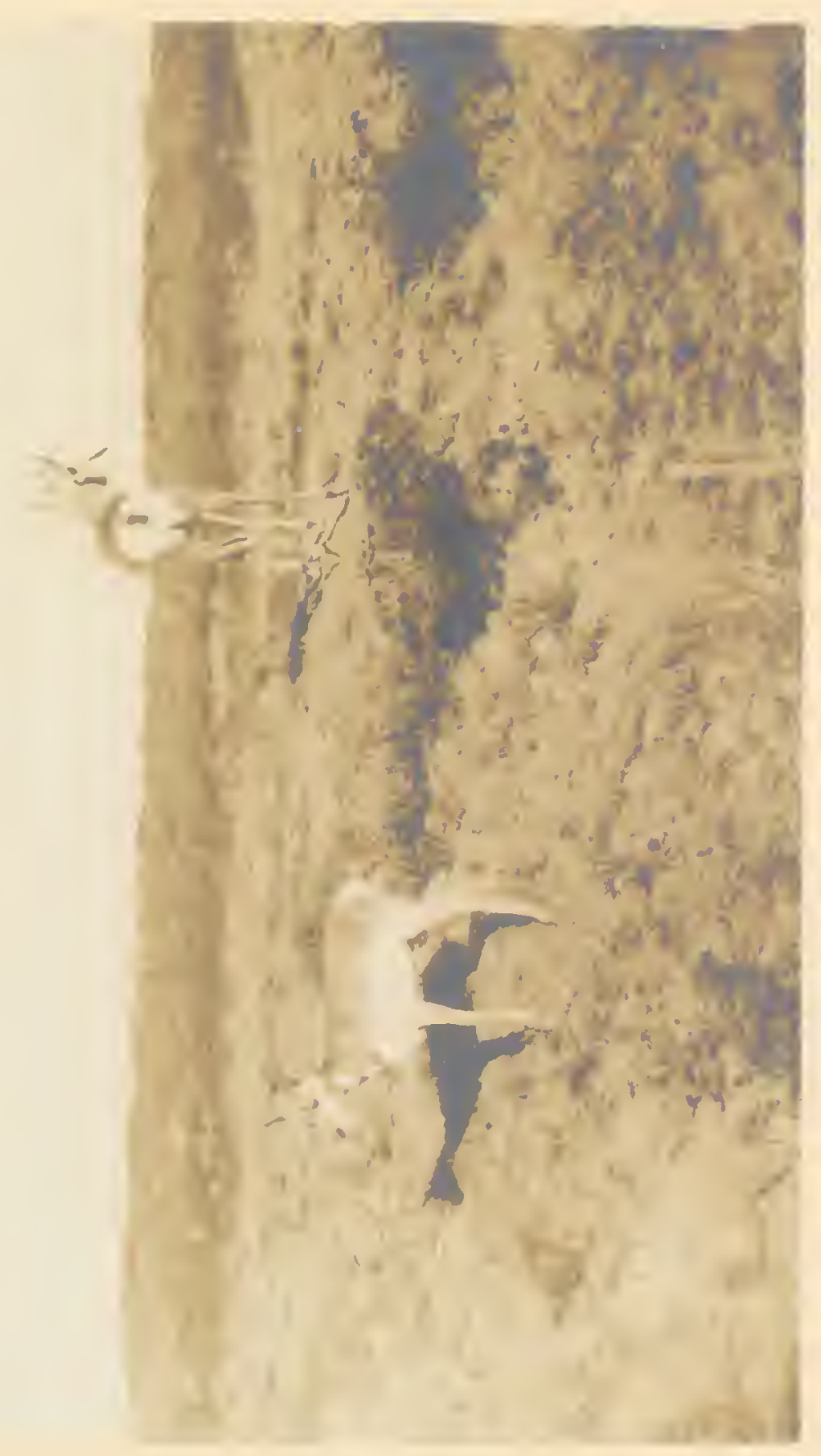




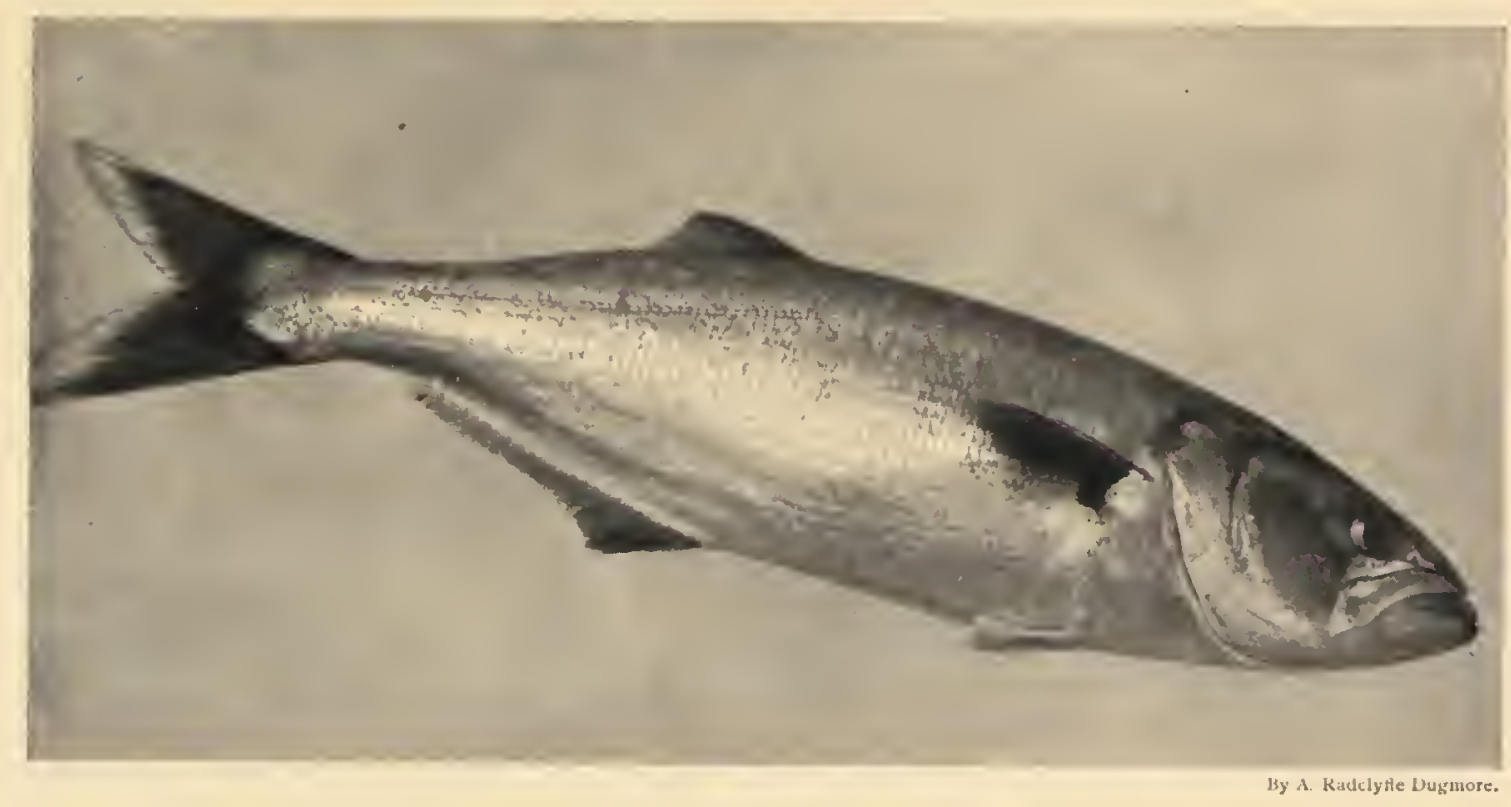

BLUEFISH.

only sentimental superficialism. It contributes to looseness of thought and vagueness of speech. But an apt figure of speech or a parable will often convey a lesson when desiccated literalism will not.

I like Bryant's lyric because it catches so much of the life of the bobolink. A scientific description could tell the story better, but only ornithologists read scientific descriptions. Yet I have always wished that the poet had told the whole story. The poem tells us of the life of the bobolink; but after the breeding season is past, the birds gather in flocks in the ricefields of the South and are then known as rice-birds. In great numbers they are slaughtered for the market, and thereby the bobolink does not become an abundant species in the North. May we not add:

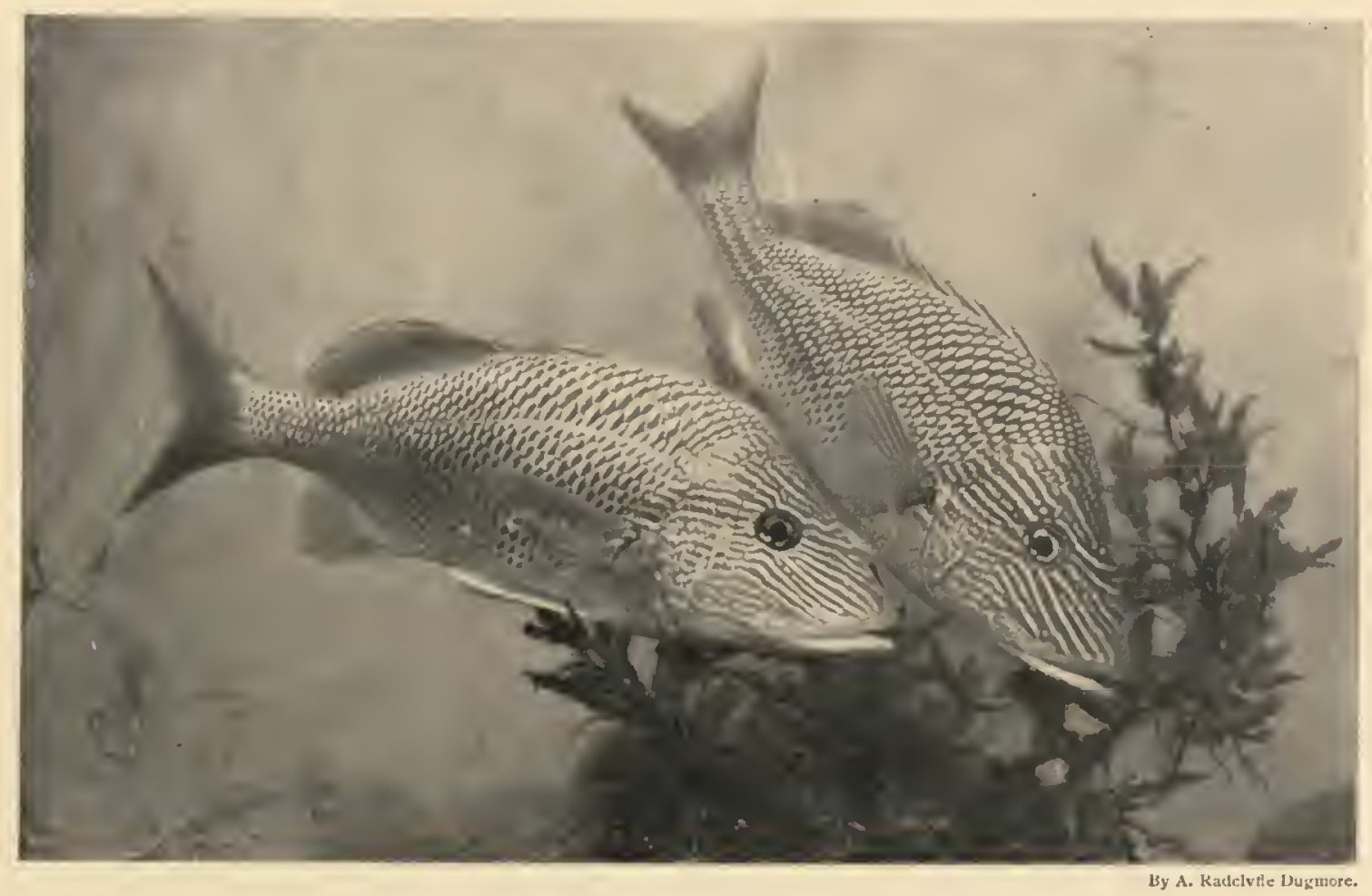

WHITE OR COMMON GRUNT. 
Far in the South he gathers his clans, Nor thinks of the regions of ice;

Too early yet for housekeeping plans,

He rev'ls and gluttons in fields of rice.

Rice-bird, bob-o'-link,

Spink, spank, spink;

Hunter is waiting under the bloom,

Robert of Lincoln falls to his doom.

Chee, chee, chee.

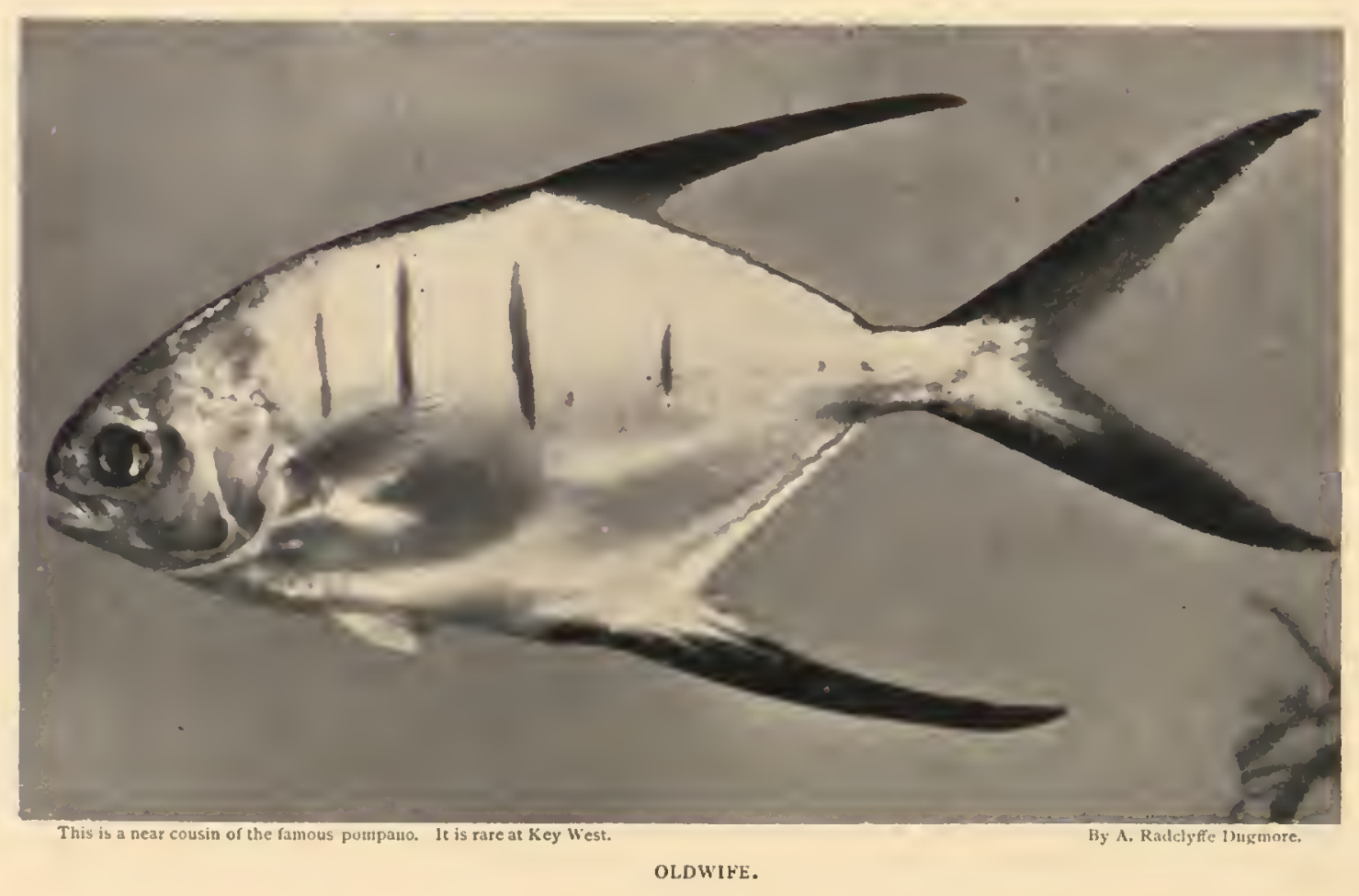

Spring comes: swinging on brier and weed,

Near to the nest of his little dame,

Over the mountain-side and mead,

Another proud groom is telling his name:

Bob-o'-link, bob-o'-link,

Spink, spank, spink;

The meadow belongs to wife and me,-

Life is as happy as life can be.

Chee, chee, chee.

The spirit of science lends itself well to song. The concrete is not unpoetic. If in this day we apostrophize and personify nature less, we have improved in the spirit and intimacy of our song. The point of view gradually has shifted from human interest in natural things to the things themselves. 
